\title{
Big City, Tiny House
}

by

James Bartlett

A thesis submitted to the Faculty of Graduate and Postdoctoral Affairs in partial fulfillment of the requirements for the degree of

Master

in

Architecture

Carleton University

Ottawa, Ontario

(C) 2016, James Bartlett 


\section{Abstract}

This thesis proposes an urban interpretation of the contemporary minimalexistence movement proposed by the Tiny House manifesto. Baltimore Maryland with its prolific and predominant row-house typology was selected as the host city. Built as traditional harbour-worker housing, Baltimore's row-houses have become derelict in large numbers as developers and officials look for viable solutions. In an attempt to curb urban decay and to promote inner-city renewal, the Tiny House principles are interpreted as alternative ways of dwelling in urban neighbourhoods.

An urban mapping and analysis of some of Baltimore's key central neighbourhoods reveals the diversity of the communities and their inhabitants. The Tiny Urban House, proposed in this thesis project, will therefore reflect this diversity while proposing an alternative model for the rehabilitation of decaying row-homes and the renewal of fading communities. 


\section{Acknowledgements}

First and foremost, to my advisor, Yvan Cazabon, whose stories and suggestions provided not only entertainment but infinite wisdom that guided us throughout the year. Somehow Yvan possesses the ability to provide motivation and inspiration every week, even when there is none within myself. The work continues however, as my summer movie and reading list is now quite extensive after so many discussions. Thank you.

To my thesis group, Paige and Ulrich, who acted more than just friends but a support system when the stress became unbearable. Being a part of your process as well allowed me to learn about different topics and ways of representation that are representative of self, that have helped me to define my own style.

Thank you.

To our thesis group, whose collective ideas, imagination and energy helped carry all of us to the finish line. As much as we pushed our own agendas, the atmosphere that was created in studio created a united push to motivate ourselves.

Thank you.

To my family and friends, whose efforts to check up on my mental and physical state did not go unnoticed. For the late night talks, the undying support, and monthly shipments of banana bread.

Thank you. 


\section{Table of Contents}

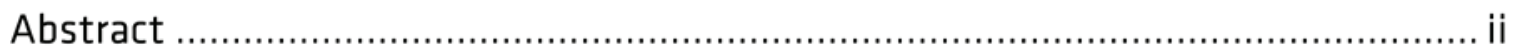

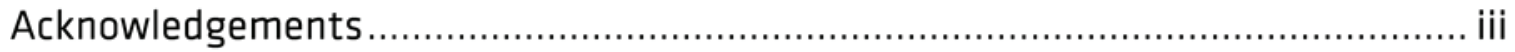

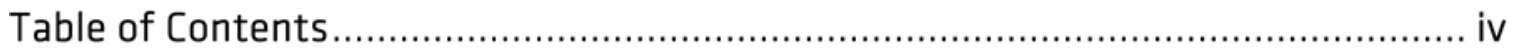

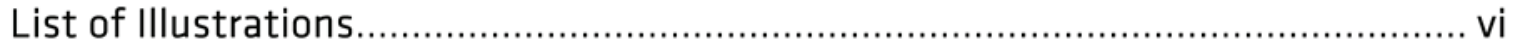

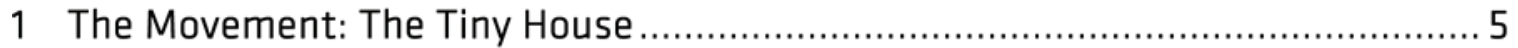

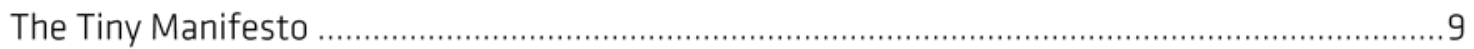

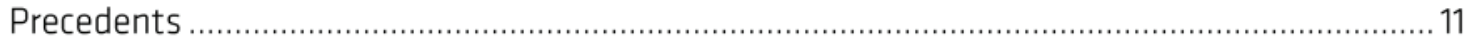

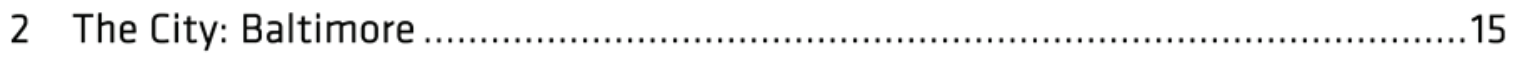

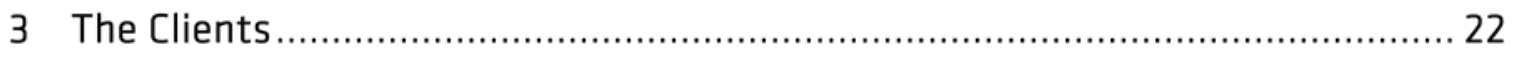

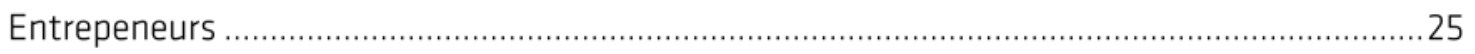

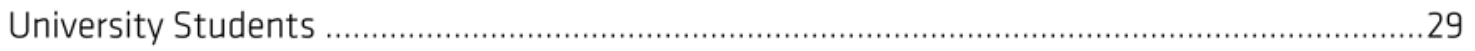

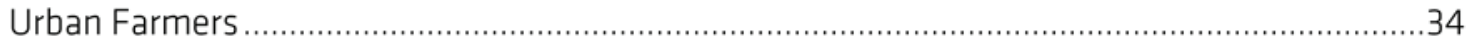

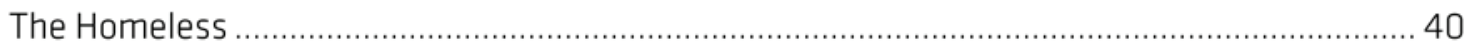

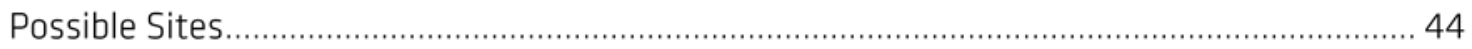

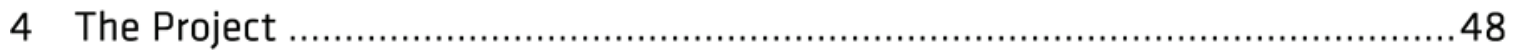

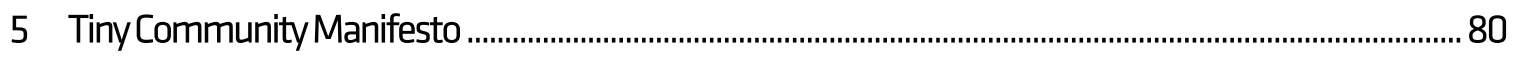

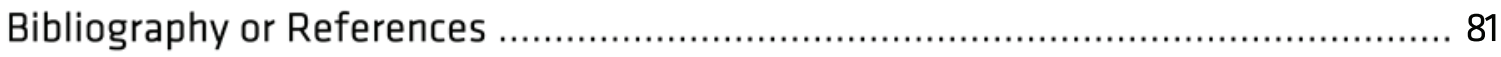

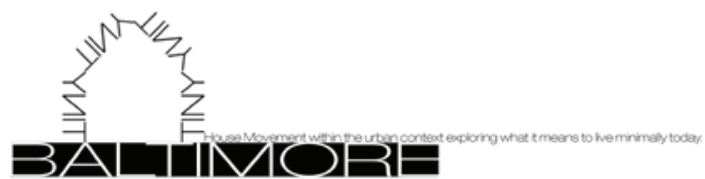




\section{List of Illustrations}

\section{*Note: All sketches, maps, photos, and drawings by author unless otherwise noted.}
Illustration 1 Yeebo, Yepoka. Baltimore. Business Insider.
$<$ http://www.businessinsider.com>
Illustration 2 Tiny House Packet Side 1.
Illustration 3 Tiny House Packet Side 2.
Illustration 4 Sketch. $\quad$........7
Illustration 5 Collage. $\quad$.......8
Illustration 6 Collage. $\quad$........9
Illustration 7 Sketch. $\quad$........10
Illustration 8 Hurt, Sam. Heimsath Architecture Blog.
Illustration 9 a) Stobel, Tammy. HGTV.com.
b) Washington, DC. Tiny, The Movie. <http://tiny-themovie.com> ........11
Illustration 10 Collage. $\quad$........12
Illustration 11 Baltimore Packet Side 1.
Illustration 12 Baltimore Packet Side 2.
Illustration 13 Skyline Graphic. $\quad$........15
Illustration 14 a) Pease, Greg. Baltimore Collegetown.
< http://www.baltimorecollegetown.org/>
b) Baltimore. Reading Partners. Web. <http://readingpartners.org/>.
Illustration 15 a) Robinson, Chuck. Chuck Robinson Photography. <http://www.chuckrobinsonphoto.com/>
b) Baltimore. Anatomy of a Rowhouse. <https:// baltimorebrickbybrick.com/category/anatomy-of-a-rowhouse/>

Illustration 16 a) Robinson, Chuck. Chuck Robinson Photography. <http://www.chuckrobinsonphoto.com/>

b) Baltimore. Vadher, Kalgi.

c) Bovard, James. Dr Rich Swier. <http:// http://drrichswier.com> ........17

Illustration 17 Map of Baltimore. $\quad$........19

Illustration 18 Collage. $\quad$.......20

Illustration 19 Merber, Tyler. Baltimore Fishbowl. .......21 <http://www.baltimorefishbowl.com/>.

Illustration 20 Entrepeneur Packet Side 1.

Illustration 21 Entrepeneur Packet Side 2.

Illustration 22 University Students Packet Side $1 . \quad$.......27

Illustration 23 University Students Packet Side $2 . \quad$.......28

Illustration 24 University Students Section. $\quad$........31

Illustration 25 Urban Farmers Packet Side 1. ........32

Illustration 26 Urban Farmers Packet Side 2. 
Illustration 27 Urban Farmers Section.

Illustration 28 Homeless Packet Side 1.

Illustration 29 Homeless Packet Side 2.

Illustration 30 Homeless Section. $\quad$.......42

Illustration 31 Collage. $\quad$.......43

Illustration 32 Site Map. $\quad$........44

Illustration 33 Site Map.

Illustration 34 Site Map. $\quad$........46

Illustration 35 Site Map. $\quad$ …....47

Illustration 36 Photo. $\quad$........49

Illustration 37 Photo. $\quad$........49

Illustration 38 Photos. $\quad$........50

Illustration 39 Photos.

Illustration 40 Drawing. $\quad$ _.......52

Illustration 41 Drawing. $\quad$........53

Illustration 42 Drawing. $\quad$........54

Illustration 43 Drawing. $\quad$........55

Illustration 44 Drawing. $\quad$........56

Illustration 45 Drawing.

Illustration 46 Photo.

Illustration 47 Photos. $\quad$.........59

Illustration 48 Drawing. $\quad$ _.......60

Illustration 49 Drawing. $\quad$ _.......61

Illustration 50 Drawing. $\quad$.......62

Illustration 51 Drawing. $\quad$........63

Illustration 52 Drawing. $\quad$.......64

Illustration 53 Photo. $\quad$.......65

Illustration 54 Drawing. $\quad$ _.......66

Illustration 55 Drawing. $\quad$.......67

Illustration 56 Photo.

Illustration 57 Drawing. $\quad$.......68

Illustration 58 Drawing. $\quad$.......69

Illustration 59 Photo. $\quad$.......69

Illustration 60 Drawing. $\quad$ _.......70

Illustration 61 Drawing. $\quad$........71

Illustration 62 Photo. $\quad$........71

Illustration 63 Drawing. $\quad$........72

Illustration 64 Drawing $\quad$........73

Illustration 65 Photo. $\quad$........73

Illustration 66 Drawing. $\quad$ _......74

Illustration 67 Drawing. $\quad$ _.......75

Illustration 68 Photo. $\quad$........75

Illustration 69 Drawing. $\quad$........76

Illustration 70 Drawing. $\quad$ _.......77 
Illustration 71 Drawing. $\quad$ …...78

Illustration 72 a) Marcin, Ben. C Grimwaldis Gallery.

<http://www. cgrimaldisgallery.com/2013/09/06/ben-marcin/>

b) Powers, Stephen. Baltimore Arts.

<http://www.baltimorearts.org/tag/steve-powers/> 


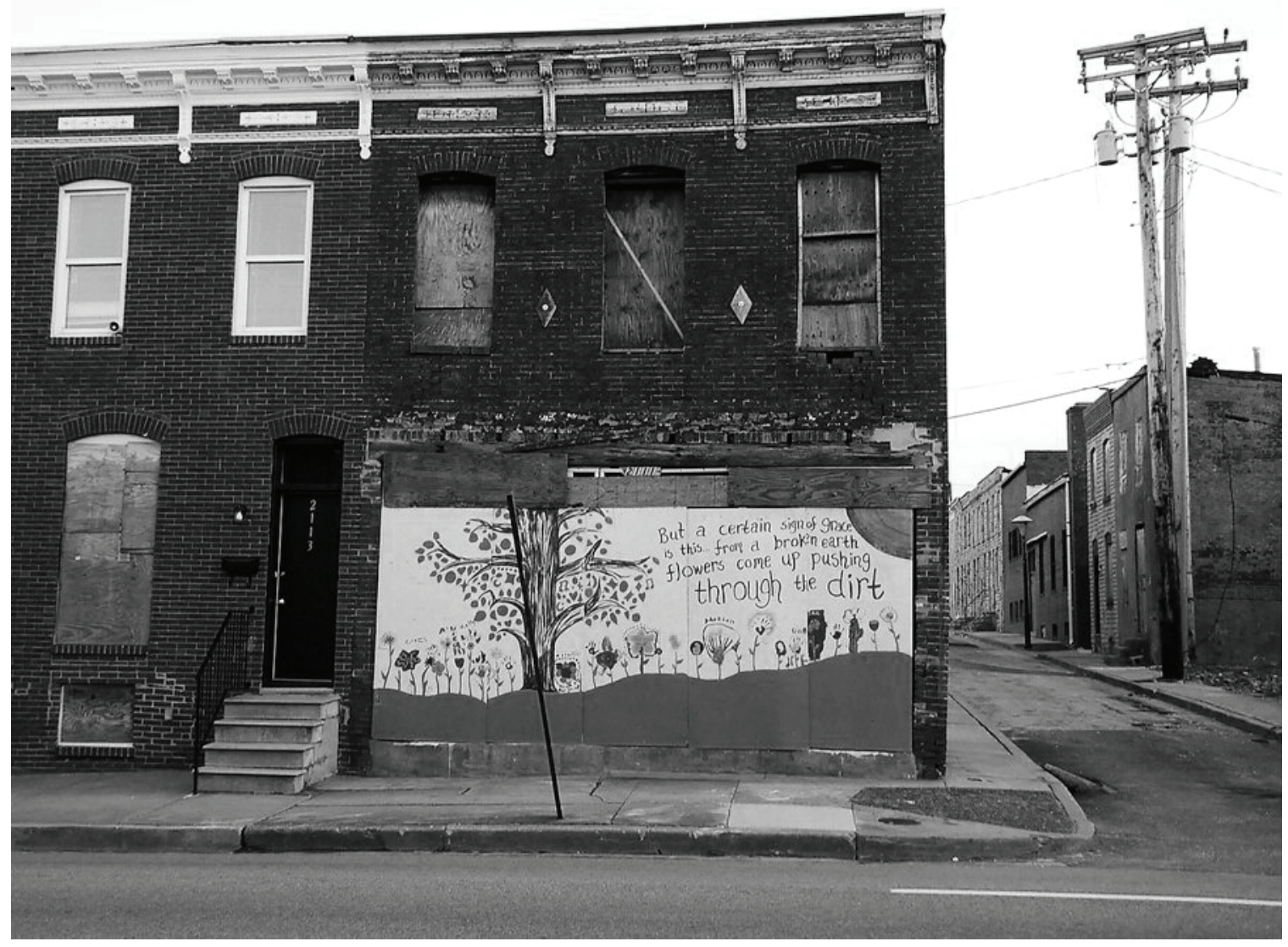

Illustration 1 Baltimore Rowhome depicting the present, and a mural depicting a possible future. 


\section{Introduction}

Minimal living as an idea is not new. The Germans implemented the notion as part of The New Objectivity in the 20s. Existenzminimum (how to design for the most efficient, minimum dwelling standards) looked at affordable housing in the wake of WWII. Today, the average residential floor space per person in Hong Kong is 15 square meters (161 square feet). ${ }^{1}$ The difference between these examples and the Tiny House Movement is the later's conscious decision to change one's life, and the mindful choice to filter out the noise of life to focus on what is important. Downsizing one's living space when larger luxury spaces are available is reflective of a personal realization to raise above the restraints placed upon us since birth by a system meant only to serve itself.

\section{"It's not about compromising how you live, it's about figuring out how you live and how you can make that better." -Tiny House Owner}




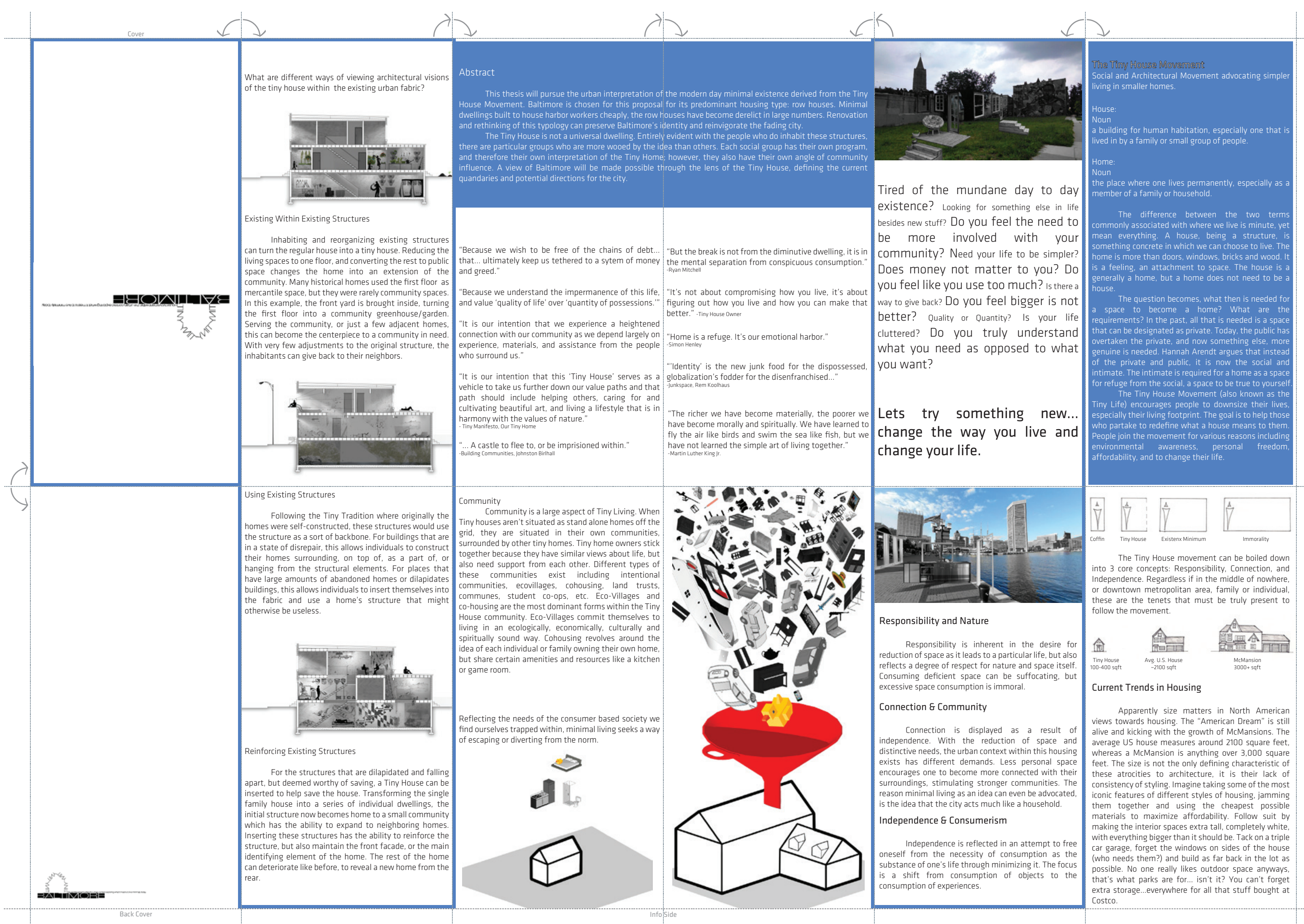

Illustration 2 Tiny House Packet Side 1. 


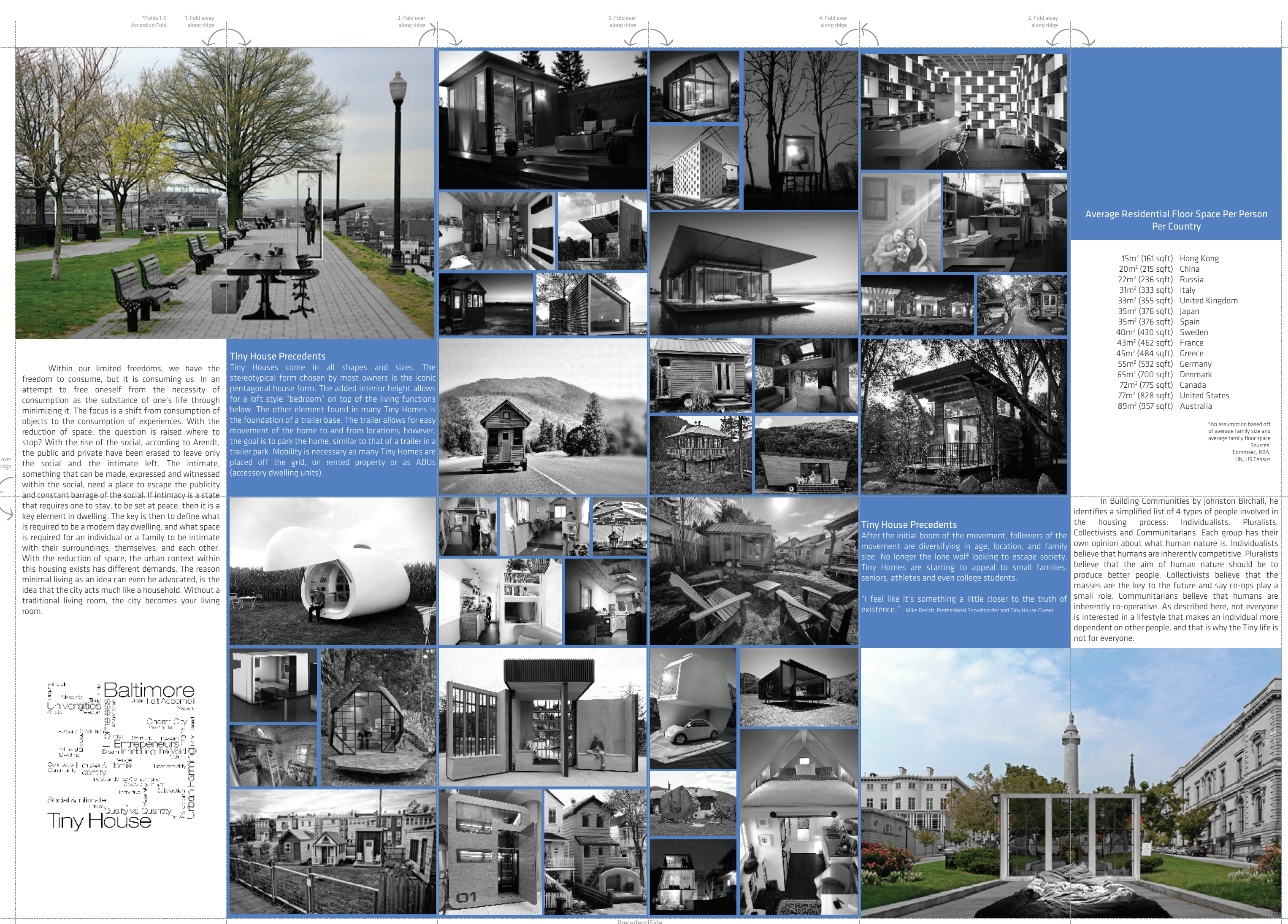




\section{The Movement: The Tiny House}

House: (Noun)

a building for human habitation, especially one that is lived in by a family or small group of people.

Home: (Noun)

the place where one lives permanently, especially as a member of a family or household.

What is needed for a house to become a home? What are the requirements? In the past, all that was needed was a space that could be designated as private. Today, the public has overtaken the private, and now something else, something more genuine is sought. Hannah Arendt argues that a home's characteristics, rather than simply the designation of the private and public, are now defined by its social and intimate delineations. ${ }^{2}$ The intimate is required for a home as a space for refuge from the social, a space to be true to oneself.

The Tiny House Movement (also known as the Tiny Life) encourages people to downsize their lives, and especially their living footprint. The goal is to help those who partake to redefine what a house is, and hence what a shouse means, to them. People join the movement for various reasons including environmental awareness, personal freedom, affordability, and a willingness to change their lives. ${ }^{3}$

2. Arendt, Hannah. The Human Condition.

3. "What Is The Tiny House Movement?" The Tiny Life. 
The Tiny House movement can be articulated by three core concepts: Responsibility, Connection, and Independence. Regardless of context, from remote locations, to dense downtown metropolitan areas, family or individual, these are the tenets that must be truly present in order to follow the movement.

\section{Responsibility and Nature}

Responsibility is inherent in the desire for reduction of space as it leads to a particular life style, but also reflects a degree of respect for nature and one's relationship to space itself. Inhabiting deficient space can be physically and psychologically suffocating, but excessive space consumption is environmentally irresponsible and immoral.

\section{Connection \& Community}

Connection is displayed as a result of independence and interdependence. With the reduction of space and distinctive needs, the urban context within which this housing is proposed has different, perhaps more refined, demands. Less personal space encourages one to become more connected with one's surroundings, stimulating stronger community ties and relationships. Minimal living, as a concept, can be advocated based on the idea that the city, like a household, provides for the needs of individuals and the collective alike.

\section{Independence \& Consumerism}

Independence is reflected in the attempt to free oneself from the pressures of consumption, deflecting its importance as the substance of one's life through minimizing it. The focus is a shift from consumption of objects to an engagement with experiences. 


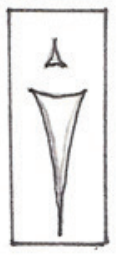

Coffin

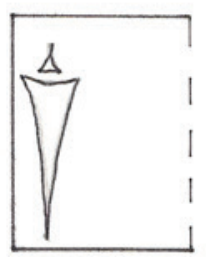

Tiny House

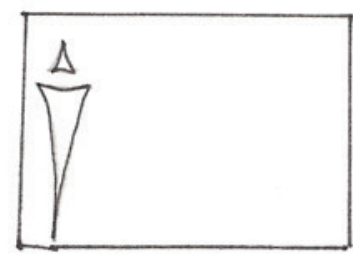

Existenz Minimum

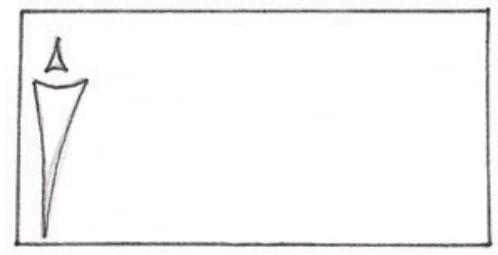

Immorality

Illustration 4 Tiny Living exists inbetween claustrophobia and the average home.

Within our limited freedoms, we have the freedom to consume, but it is consuming us. Scaling back is an attempt to free oneself from the necessity of consumption as the substance of one's life through minimizing it. The focus is a shift from consumption of objects to the investment in experiences. With the reduction of space, the question is raised where to stop? According to Arendt, with the rise of the social, the public and private have been erased to leave only the social and the intimate. ${ }^{4}$ The intimate, something that can be made, expressed and witnessed within the social, needs a place to escape the publicness and the constant barrage of the social. If intimacy is a state that requires one to stay, to be set at peace, then it is a key element in dwelling. The challenge then is to define what is required to be a modern day dwelling, and what space is required for an individual or a family to be intimate with their surroundings, themselves, and each other. With the reduction of space, the urban context within which this housing exists has different demands. Minimal living as a concept and new typology can be advocated is based on the idea that the city acts much like an extended household. Without a traditional living room, the city becomes the Tiny House's living room. 


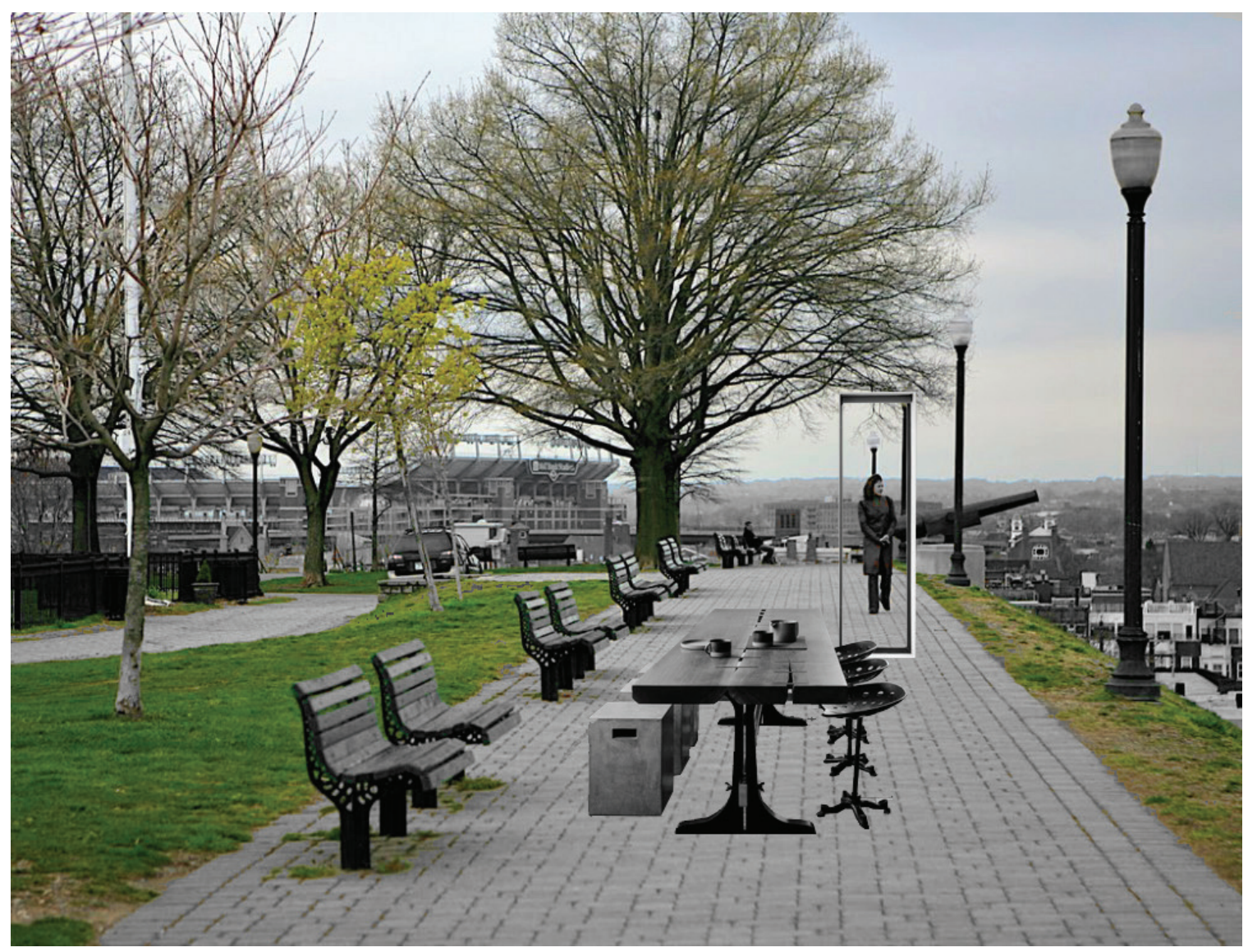

Illustration 5 Federal Hill envisioned as a Tiny Dweller's Dining Room. 
Tiny Manifesto

Mitchell Mast, Nicholette Codding

OurTinyHome.com

"Because we wish to be free of the chains of debt... that... ultimately keep up tethered to a system of money and greed."

"Because we understand the impermanence of this life, and value 'Quality of Life' over 'Quantity of Possesions."”

"It is our intention that we experience a heightened connection with our coomunity

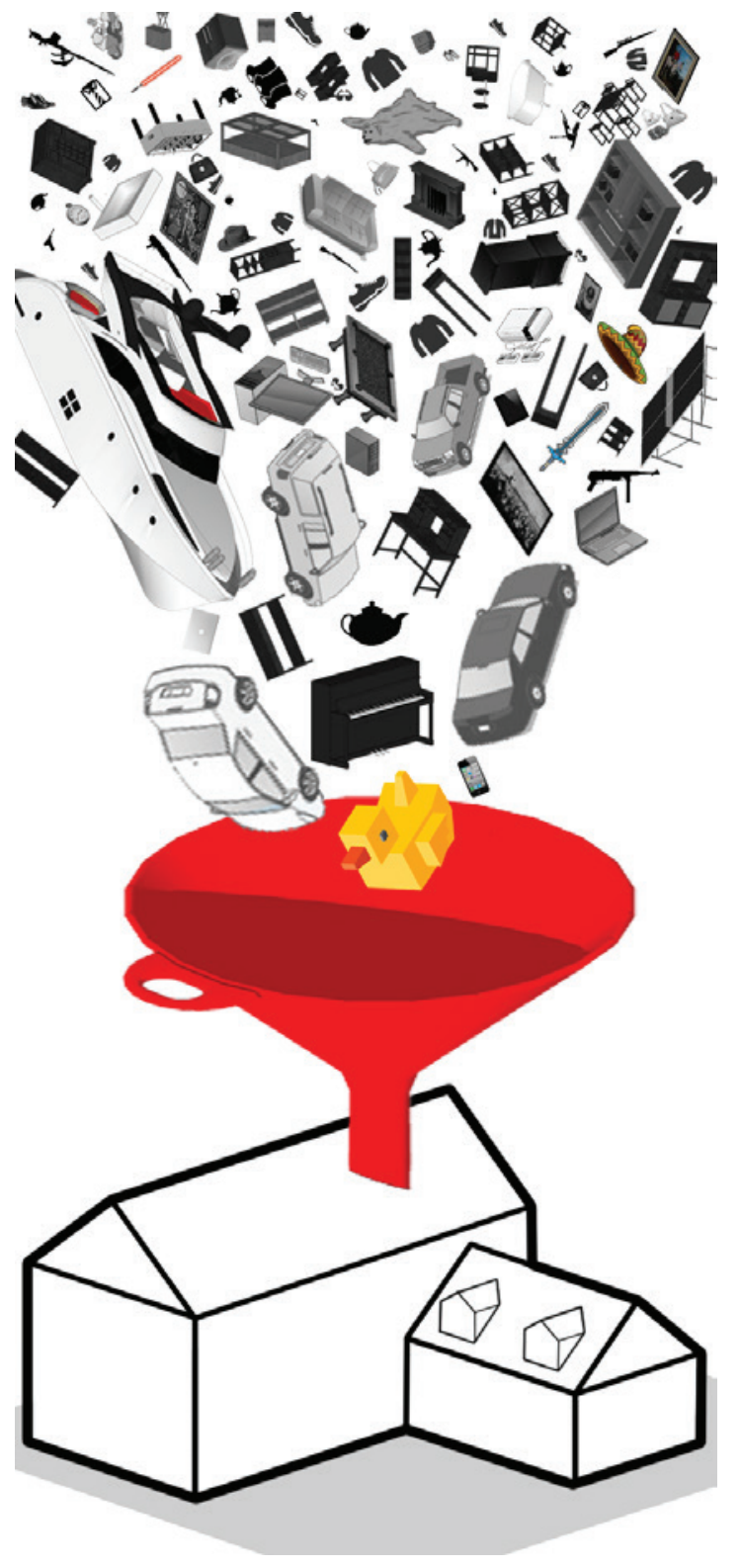
as we depend largely on experience, materials, and assitance from the people who surround us."

"It is our intention that this "Tiny House' serve as a vehicle to take us further down our value paths. And that path should include helping others, caring for and cultivating the land which sustains us, creating beautiful art, and living a lifestyle that is in harmony with the values of nature."

Illustration 6 Less space, Less stuff. What do we really need? 


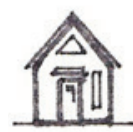

Tiny House 100-400 sqft

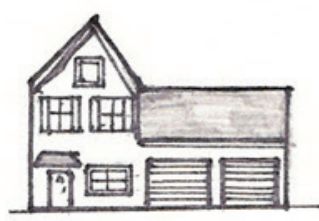

Average US House $\sim 2100$ sqft

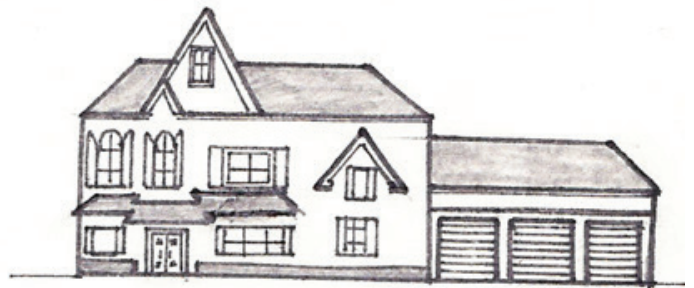

McMansion $3000+$ sqft

Illustration 7

Sketch depicting the varying scales of modern homes comparied to the typical Tiny Home.

Current Trends in Housing

Apparently size matters in North America's views regarding housing. The "American Dream" is still alive and booming with the continuing growth of McMansions. The average US house measures approximately 2100 square feet, whereas a McMansion is anything over 3,000 square feet. The development and popularity of these homes demonstrates consumerism's mantra of "Bigger is Better." Tiny Living acts in stark contrast by containing the home from 100-400 square feet.

\section{"I feel like it's something a little closer to the truth of existence." - Mike Basich, Professional Snowboarder and Tiny House Owner}

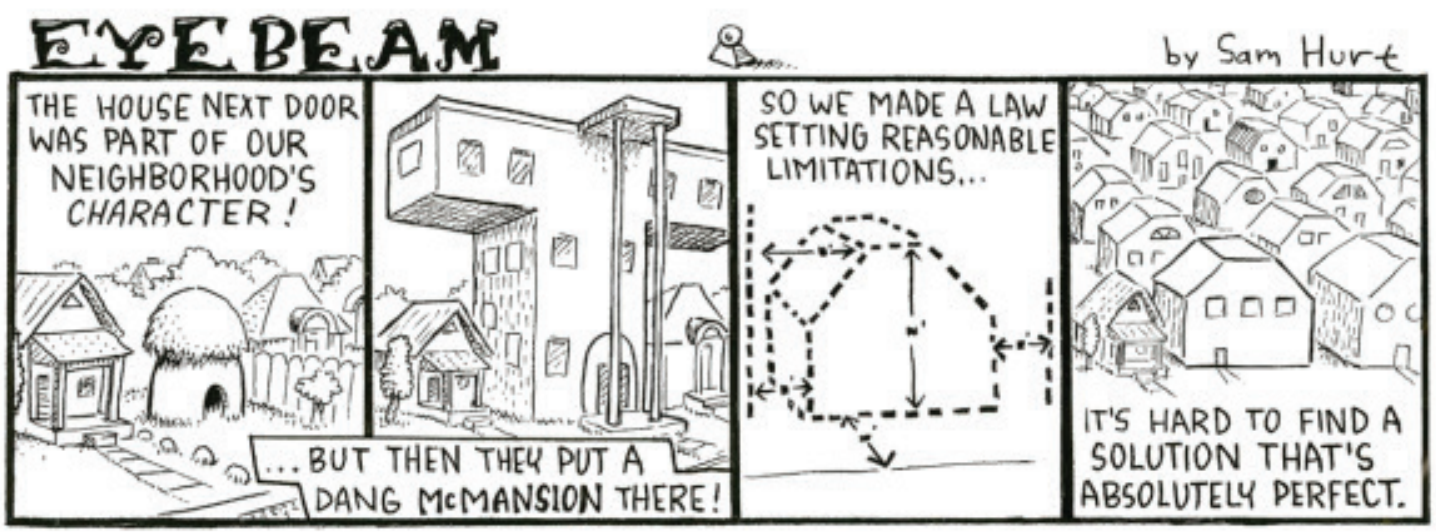

Illustration 8 Comic depicting the nature of McMansions, especially where they do not belong. 

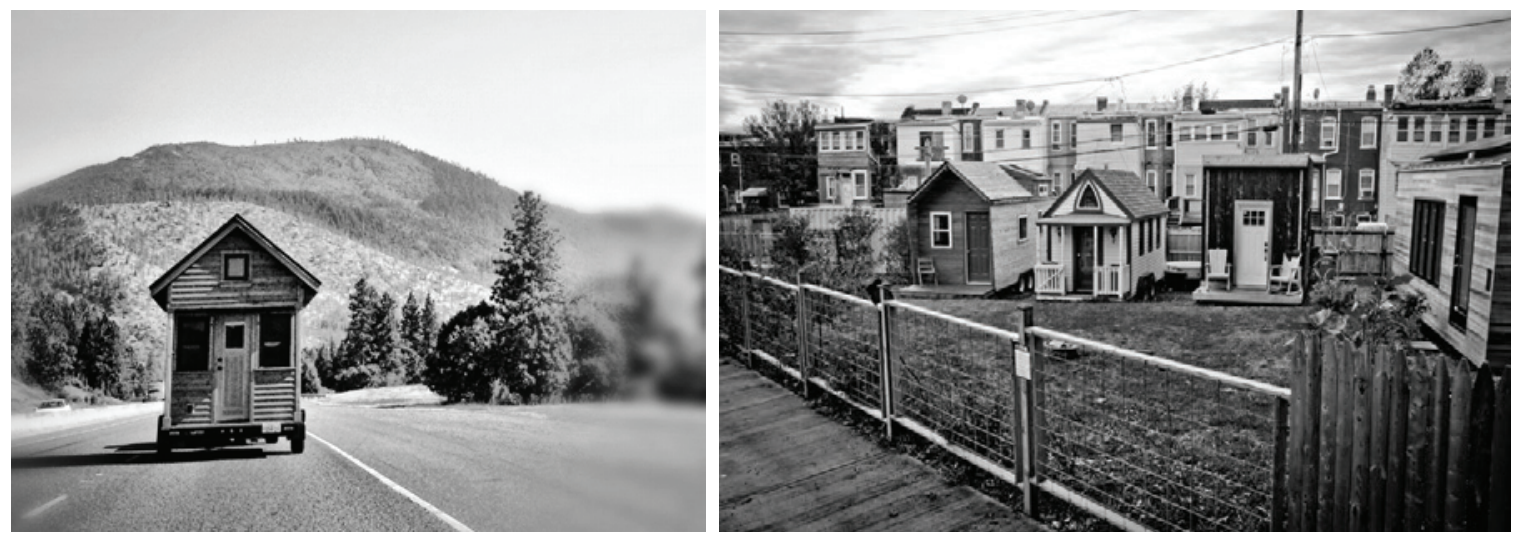

Illustration 9 Two sides to the movement: the Lone-Wolf and the pocket community.

\section{Tiny House Precedents}

After the movement's initial boom, Tiny House adopters have been diversifying in age, location, and family size. No longer the lone wolf looking to escape society, Tiny Homes are beginning to appeal to small families, seniors, athletes and even college students.

Community engagement is a large aspect of the Tiny Living movement. In contrast to Tiny houses that are situated as off-grid, standalone homes, Tiny Living communities are situated within a cluster or grouping, surrounded by other tiny homes. Owners within these clusters stick together because they share similar life philosophies, while benefiting from the support of other like-minded people. Varying types of grouped communities have been built based on experimental models including intentional communities, eco-villages, cohousing, land trusts, communes, and student co-ops, to name a few. Eco-Villages and co-housing are the most dominant forms within the Tiny House communities in North America. Eco-Villages commit themselves to living in an ecologically, economically, culturally and spiritually sound way. The Cohousing model revolves around the idea that each individual or family owns their own home, but share certain amenities and resources like kitchens or game rooms, with neighboring families. ${ }^{5}$

5. "Ecovillage, Intentional Community, Cohousing, Cooperatives, Sustainable Community." PlanetFriendly Guide to Community. 
Tiny Houses come in all shapes and sizes. The stereotypical form chosen by most owners is the iconic pentagonal house form. The added interior height allows for a loft style "bedroom" on top of the living functions below. The other element found in many Tiny Homes is the provision of a trailer base. The trailer allows for easy movement of the home to and from locations. The goal however is to park the home, in a similar manner as to that of a trailer in a trailer park. Mobility is necessary as many Tiny Homes are placed off the grid, on rented property or as ADUs (accessory dwelling units).

"The richer we have become materially, the poorer we have become morally and spiritually. We have learned to fly the air like birds and swim the sea like fish, but we have not learned the simple art of living together."

-Martin Luther King Jr.

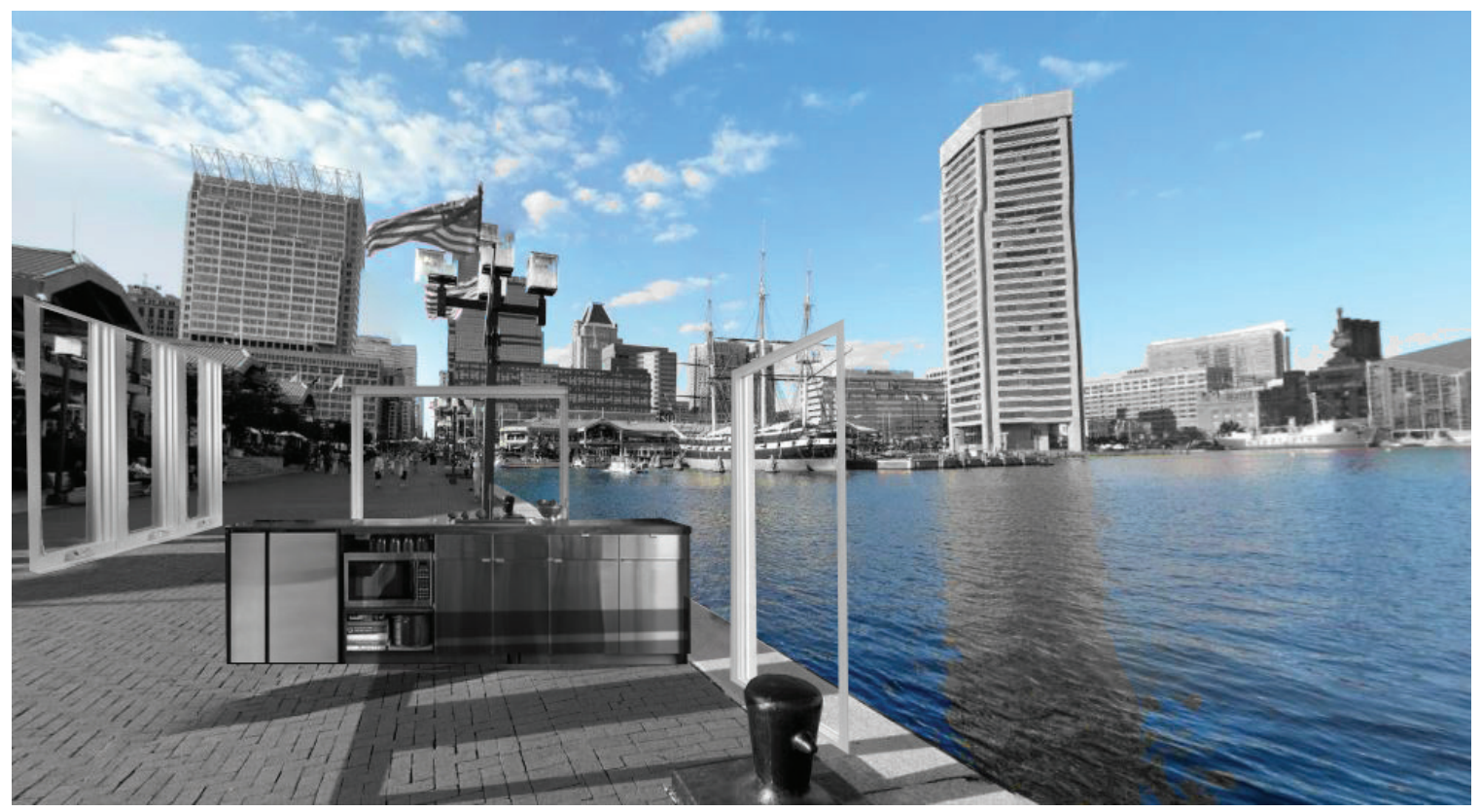

Illustration 10 Renvisioning the Inner Harbor with Tiny Living. 


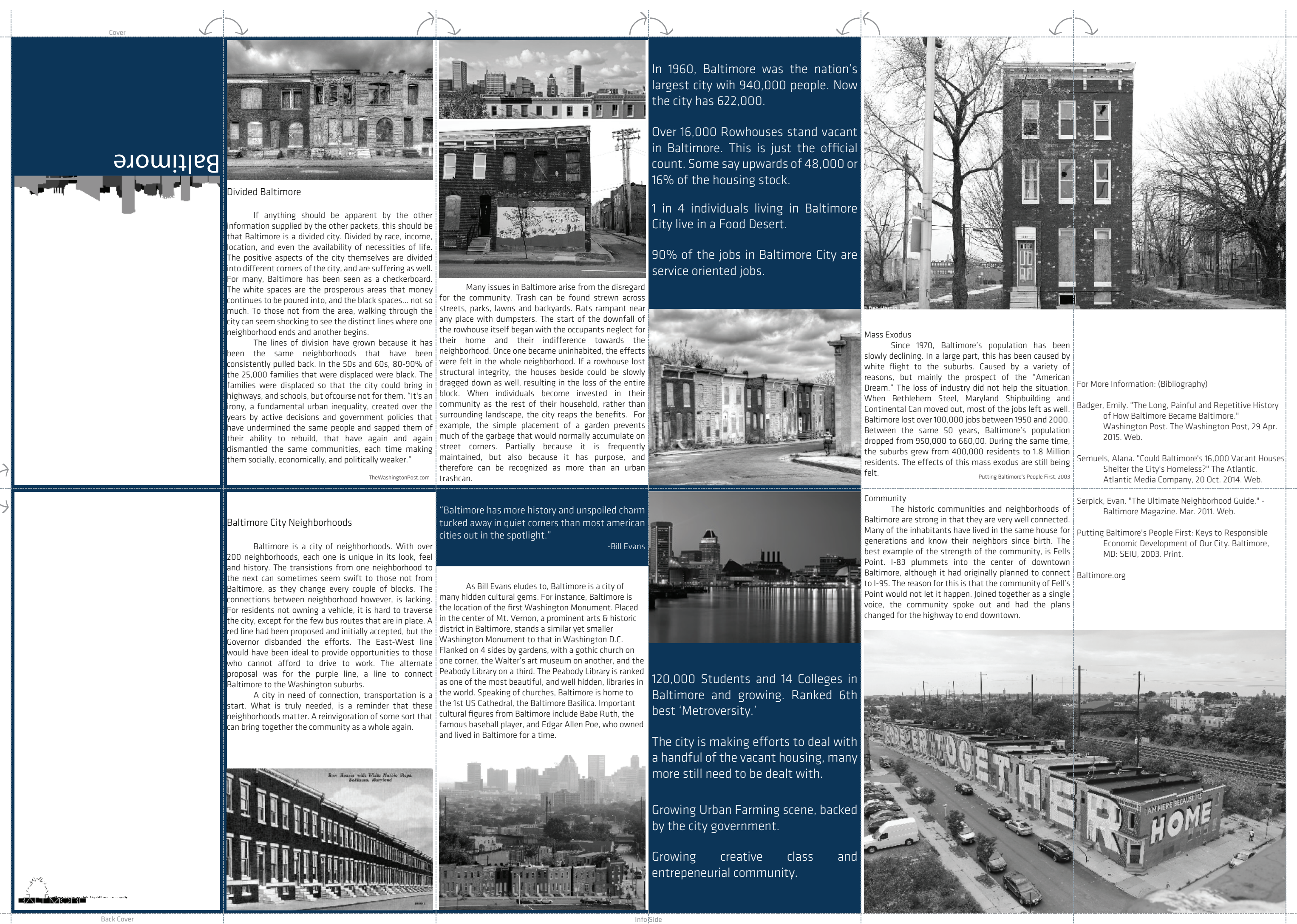




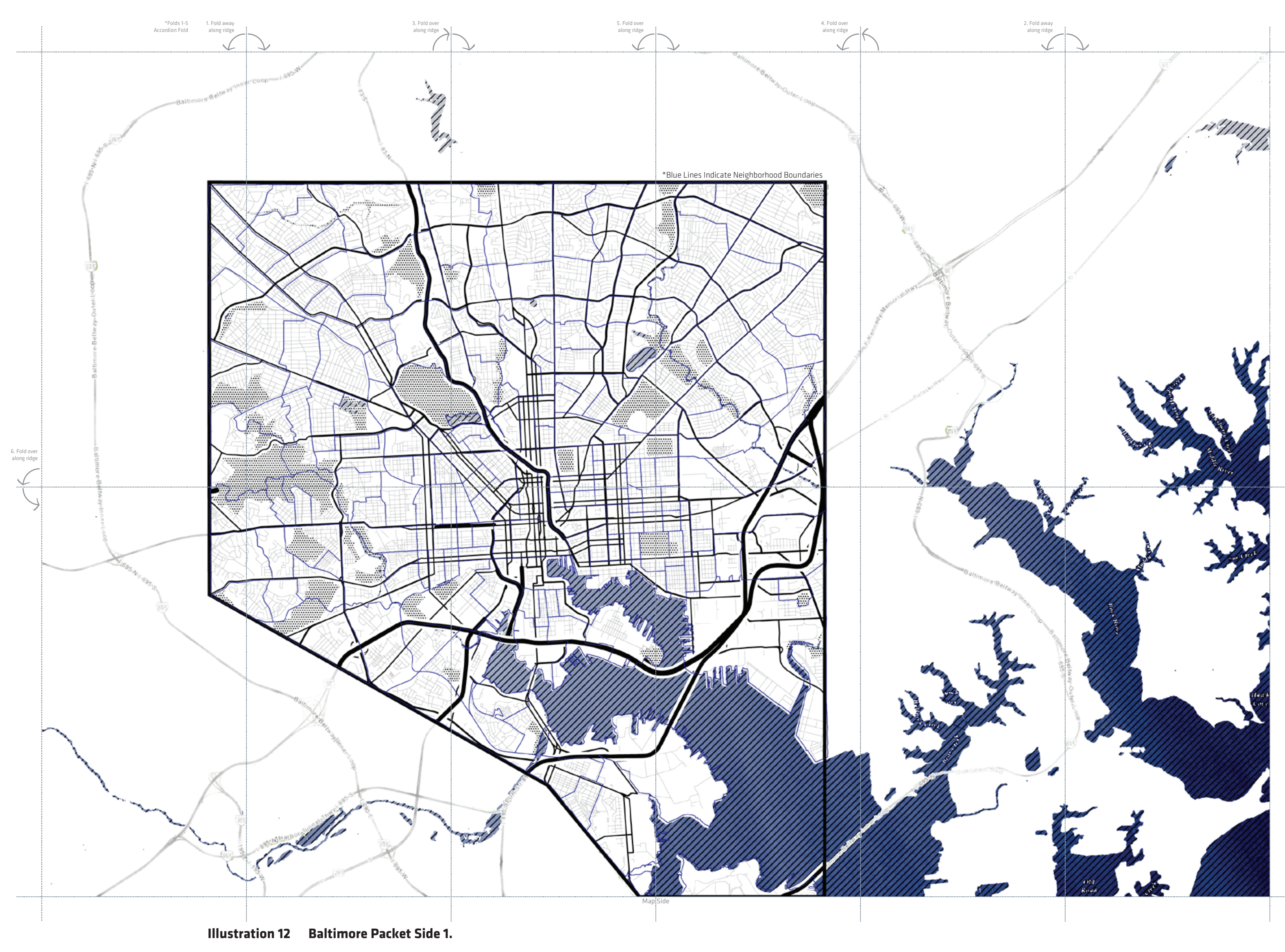




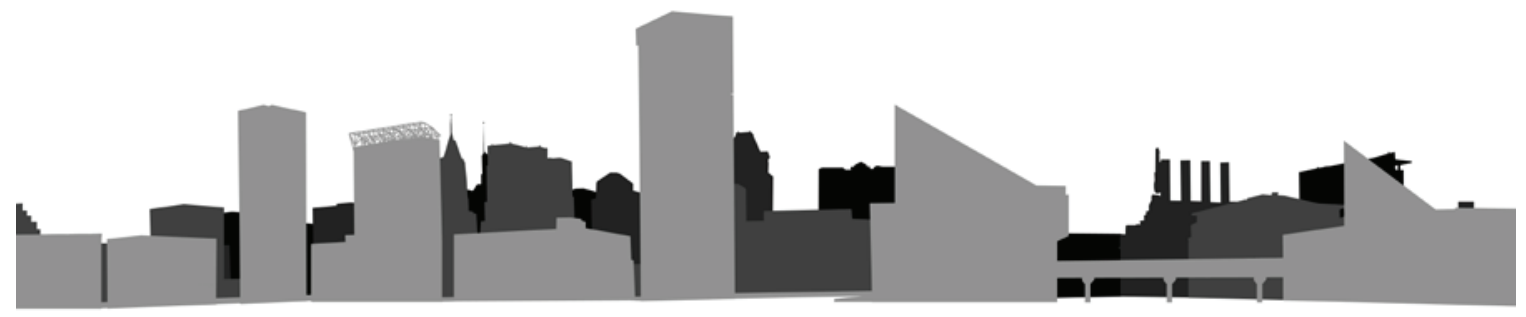

\section{Illustration 13 Graphic of Baltimore's skyline.}

\section{The City: Baltimore}

Baltimore's numerous communities are segregated by race, income, location, and in the most extreme cases, the availability of the basic necessities of life. The positive aspects of the city are themselves scattered throughout diverse corners of the city; these qualities are threatened as well. For many, Baltimore is seen as a checkerboard. The white spaces are the prosperous areas into which money continues to be poured, and the black spaces with hardly a trickle of investment. To outsiders unaccustomed to the struggling areas, the city can appear shockingly seperated with distinct lines where one neighborhood ends and another begins. The lines of division have expanded from the same neighborhoods that have been consistently held back. In the 50 s and 60s, 25,000 families in central areas were displaced in order to bring in highways, schools and services for outlying communities. Notably, $80-90 \%$ of the displaced families were African-

"It's an irony, a fundamental urban inequality, created over the years by active decisions and government policies that have undermined the same people and sapped them of their ability to rebuild, that have again and again dismantled the same communities, each time making them socially, economically, and politically weaker."7

\footnotetext{
6. Badger, Emily. "The Long, Painful and Repetitive History of How Baltimore Became Baltimore."

7. Ibid.
} 

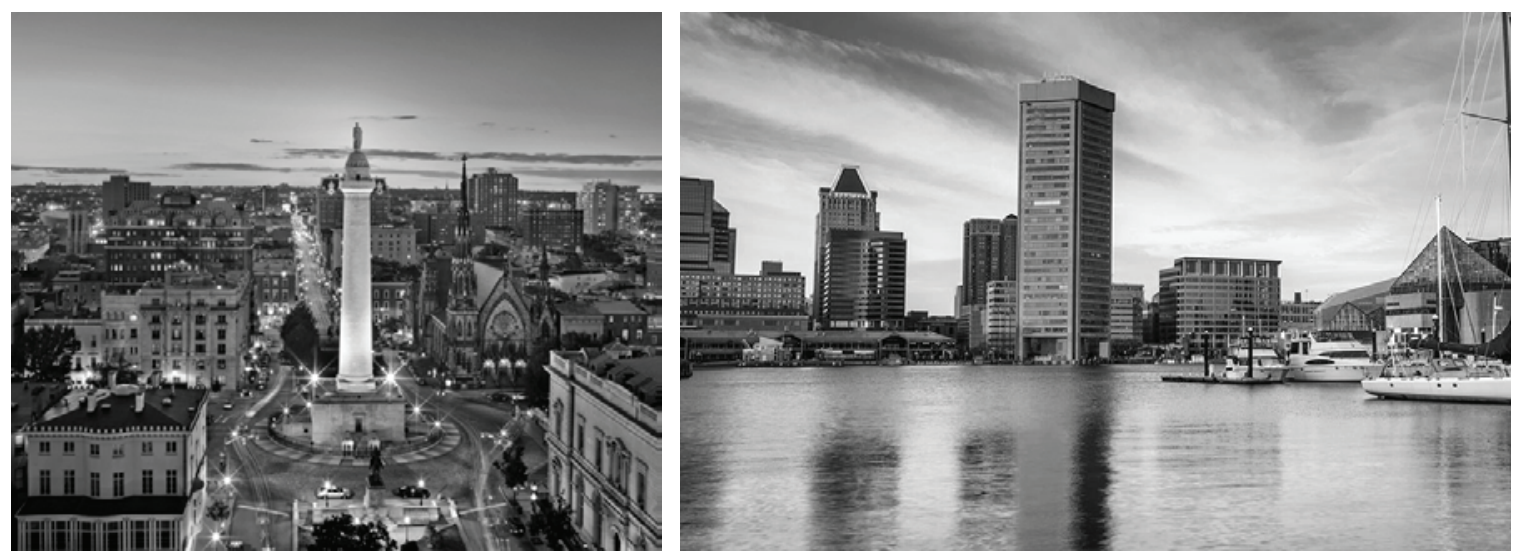

Illustration 14 Prosperous districts of Baltimore. Left: Mount Vernon, Right: The Inner Harbor.

In 1960, Baltimore was the nation's largest city wih 940,000 people. Now the city has 622,000.

Over 16,000 Rowhouses stand vacant in Baltimore. Some accounts record upwards of 48,000 or $16 \%$ of the housing stock.

1 in 4 individuals living in Baltimore City live in a Food Desert.

$90 \%$ of the jobs in Baltimore City are service oriented jobs.
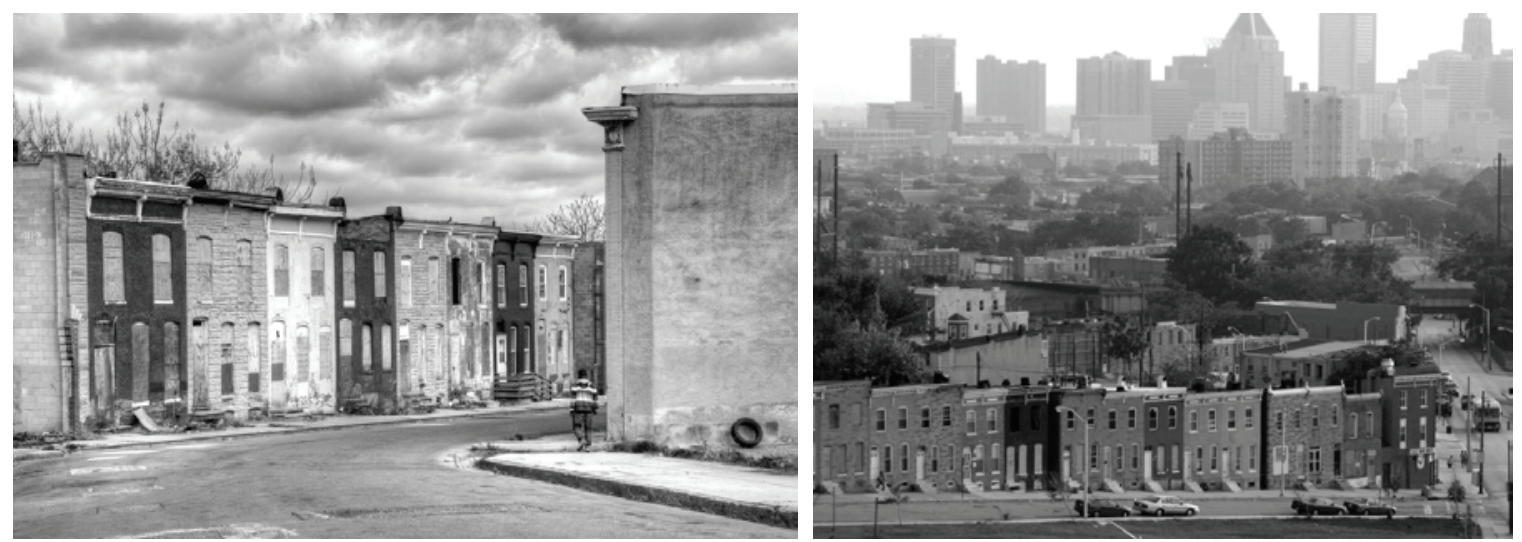

Illustration 15 The other side of Baltimore, East and West of the downtown core. 


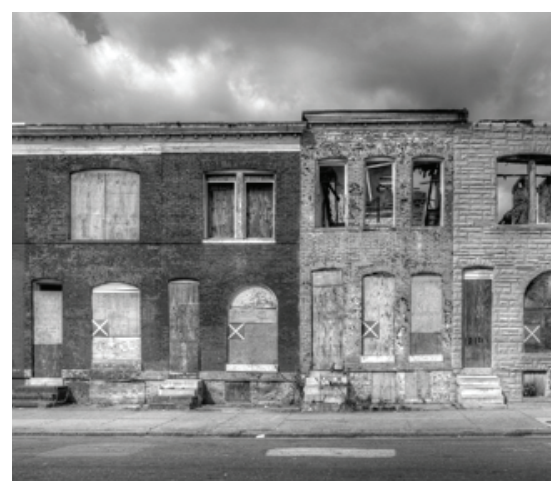

(a)

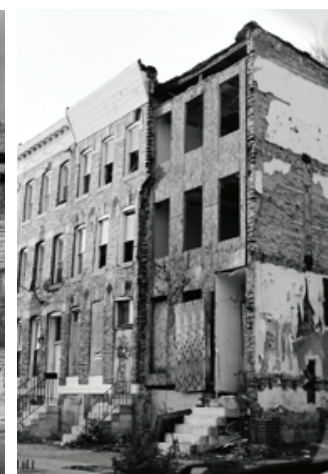

(b)

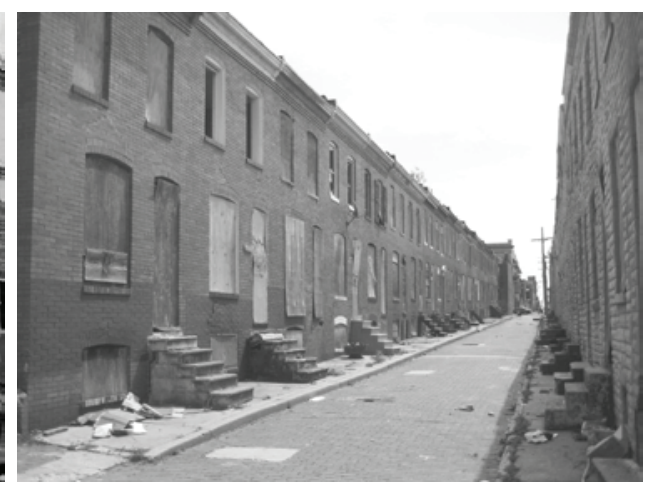

(c)

Illustration 16 Various images depicting the extent of neglect to rowhomes and communities.

American. ${ }^{6}$

Baltimore is a city of neighborhoods. There are over 200 neighborhoods, each with its unique look, feel and history. The transitions from one neighborhood to the next can sometimes seem abrupt to those unfamiliar with the city's structure. Visitors experience numerous changes within few blocks often without connections or transitions between them. For residents without a vehicle, it is difficult to traverse the city, except for the few established bus routes that serve this purpose. A red line, for the purpose of expedient transit had been proposed - and initially accepted - but the Governor disbanded the efforts. The East-West red line would have been an ideal solution to provide commuting services to those who cannot afford to drive to work. The alternate proposal was for the purple line, a line connecting Baltimore to the Washington suburbs. ${ }^{8}$ This is a city in need of connection, and expanded public transportation is an appropriate start. What is truly needed however, is a constant reminder that all neighborhoods matter and projects that inspire a reinvigoration of all zones in order to bring together and make whole the entire fractured community.

Many issues in Baltimore arise from a disregard for the community and its public spaces. Trash can be found strewn across streets, parks, lawns and backyards. Rats and 
vermin are rampant near any establishment with exposed refuse and dumpsters. The start of the downfall of the rowhouse itself began with the occupants' neglect for their homes and the apparent indifference to the greater neighborhood. Once one row house became uninhabited, the effects were felt throughout the entire row. When a rowhouse lost its structural integrity, adjacent houses would slowly degrade as well, resulting in the loss of an entire block. ${ }^{9}$ When individuals are empowered to become invested in their community as they are with their families and households, the immediate community, and by extension, the entire city reaps the benefits. For example, the simple placement of a community garden, tended by neighbours, would control much of the garbage that would normally accumulate on street corners - partially due to frequent maintenance, but also because of the street's newfound purpose, and therefore its transformation from an urban trashcan to a shared streetscape.

\section{Mass Exodus}

Since 1970, Baltimore's population has been slowly declining. This has been caused, in a large part, by white flight to the suburbs, due to a variety of reasons, but mainly driven by the idealized images and prospects of the "American Dream."10 The loss of industry did not help the situation. When Bethlehem Steel, Maryland Shipbuilding and Continental Can moved out, most of the jobs left as well. Baltimore lost over 100,000 jobs between 1950 and 2000. Between the same 50 years, Baltimore's population dropped from 950,000 to 660,000 . During the same time, the suburbs grew from 400,000 residents to 1.8 Million residents. ${ }^{11}$ The effects of this mass exodus are still being felt.

In contrast to ailing districts, the historic communities and neighborhoods of Baltimore are strong in that they are very well interconnected. Many of the inhabitants

\footnotetext{
9. Philipsen, Klaus. "Anatomy of the (Baltimore) Rowhouse."

10. Casey, Dana R. "A Child's Memory Of White Flight From Baltimore."

11. Putting Baltimore's People First: Keys to Responsible Economic Development of Our City. SEIU.
} 
have lived in the same house for generations and have known their neighbors since birth. The best example of the strength and cohesiveness of such a community, is Fells Point. The I-83 interstate plummets Baltimore, although it had connect to interstate $1-95$ urban fabric. The reason for objections by the community not let it proceed. Joined the community spoke out

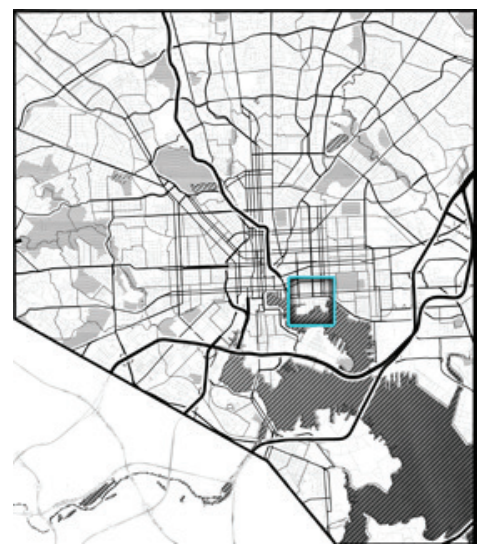
into the center of downtown originally been planned to while severing the existing this incompletion lies in the of Fell's Point who would together as a single voice, and had the plans changed for the highway to end downtown.

\section{Illustration 17 Map showing Fell's Point in relation to Baltimore as a whole.}

\section{"Baltimore has more history and unspoiled charm tucked away in quiet corners than most American cities out in the spotlight." -Bill Evans}

As Bill Evans suggests, Baltimore is a city of many hidden cultural gems. For instance, Baltimore is the location of the first Washington Monument. Placed in the center of Mt. Vernon - a prominent arts \& historic district in Baltimore - stands a monument similar to, yet smaller than, the Washington Monument in Washington D.C.. Baltimore's monument is flanked on 4 sides by gardens, with a gothic church on one corner, the Walter's art museum on another, and the Peabody Library on a third. The Peabody Library is ranked as one of the most beautiful and well hidden libraries in the world. Baltimore is also home to the 1st US Cathedral, the Baltimore Basilica. Additionally, a number of important cultural figures hail from Baltimore including Babe Ruth, the famous baseball player, and poet Edgar Allen Poe, who resided in Baltimore for a time. 


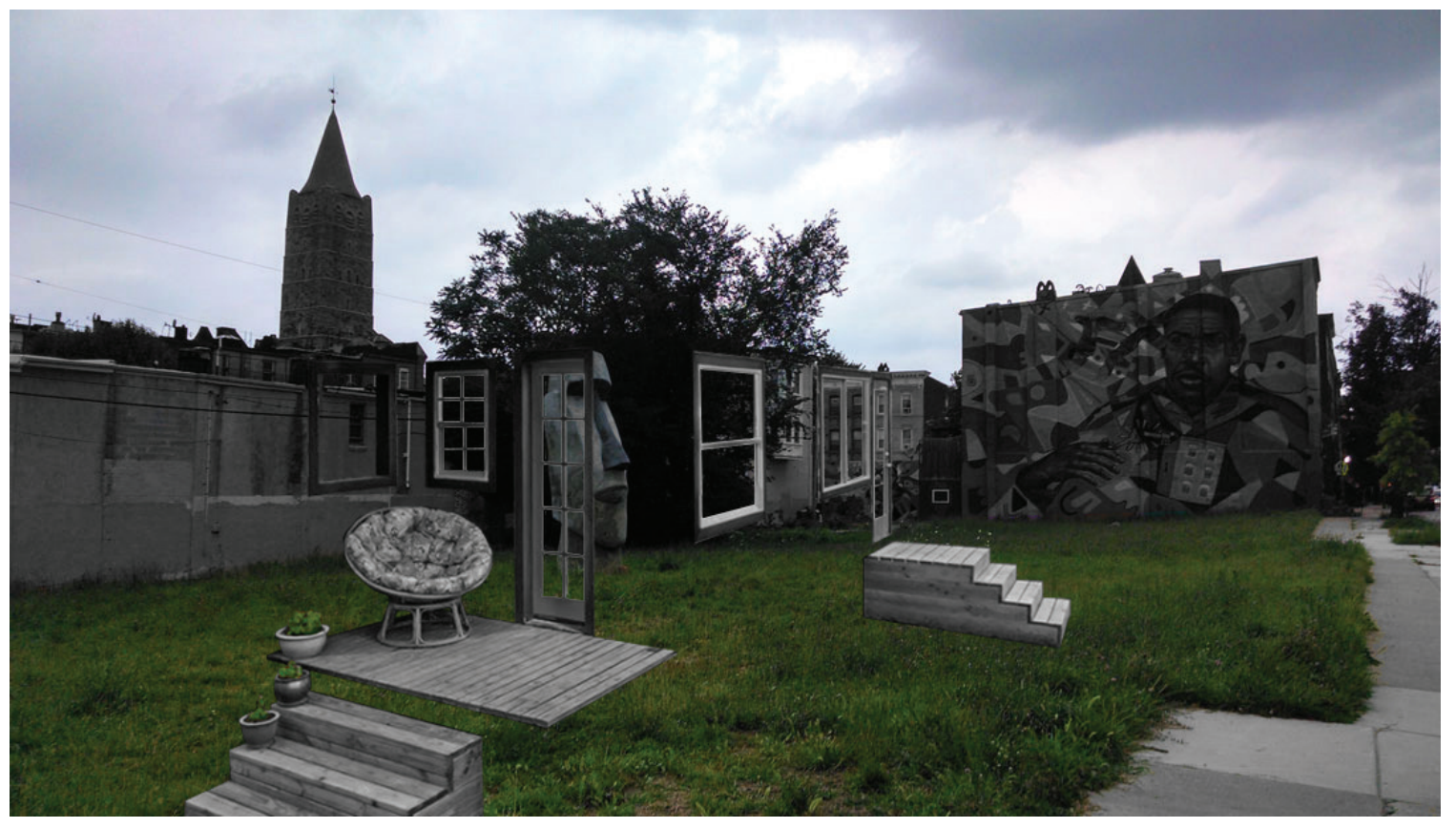

Illustration 18 Can the Tiny Home inhabit spaces that others will not, or cannot? 


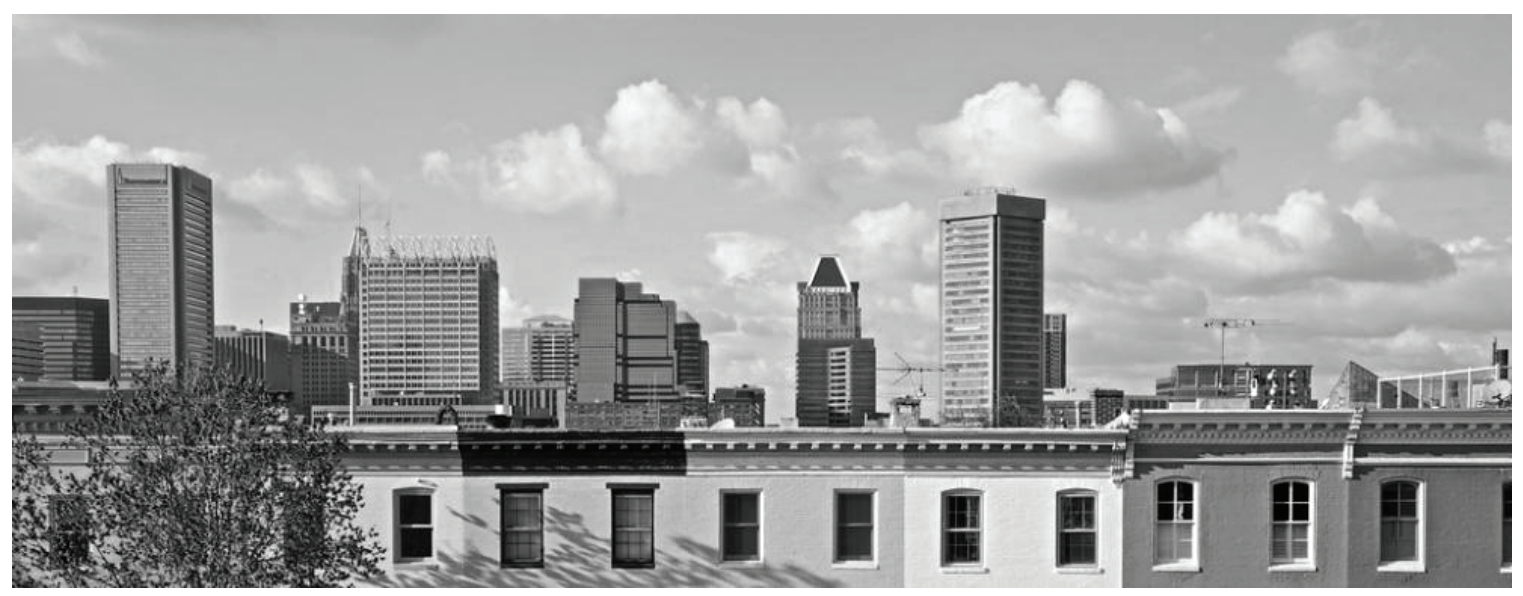

Illustration 19 The Baltimore skyline, Rowhouses and the growing downtown.

120,000 Students and 14 Colleges in Baltimore and growing. Ranked 6th best 'Metroversity.'

The city is making efforts to deal with a handful of the vacant housing, many more still need to be dealt with.

Growing Urban Farming scene, backed by the city government.

Growing creative class and entrepreneurial community.

The Unrest in Baltimore in 2016 brought international attention to the city. Images circulated of youths smashing police cars, damaging public property and confronting police officers. The events that unfolded only represented decades of abuse and segregation within the city. Once one of the largest cities in the country, Baltimore has fallen to the fate of many rustbelt cities. With the loss of industry, and deep racial divides, the city is being smothered; however, there are those that are working towards a greater Baltimore.

Four prominent groups within Baltimore have been chosen to be included within this thesis as the "clients." Included in this are the Homeless, University Students, Urban Farmers, and Entrepeneurs. Each group is growing in size, for better or worse. 


\section{The Clients}

In order to understand how Tiny Living can fit into a city, there are two things that must be understood: the city itself, and the stories of the people within the city. The city must be understood to know which cracks should be filled with the Tiny House and to what end. As an ideology about living life, the Tiny House Movement is not attempting to solve all the issues a city faces, because it cannot, nor can architecture for that matter. Specifically in the case of Baltimore, the deeply entrenched fissure between races is a dilemma that can only be cured by people.

The studies that follow attempt to create a narrative, The Story of Baltimore. They are an account of the current problems and the individuals who are currently laboring towards the creation of a better city. Identifying groups within Baltimore that are influencing the city encourages what is already occurring, as situationist response. The common thread between these stories is the need for connection. Connection to each other, their community, and their city. Those who live Tiny, make the city their household, and therefore are more interested in cleaning up their city and promoting change. 


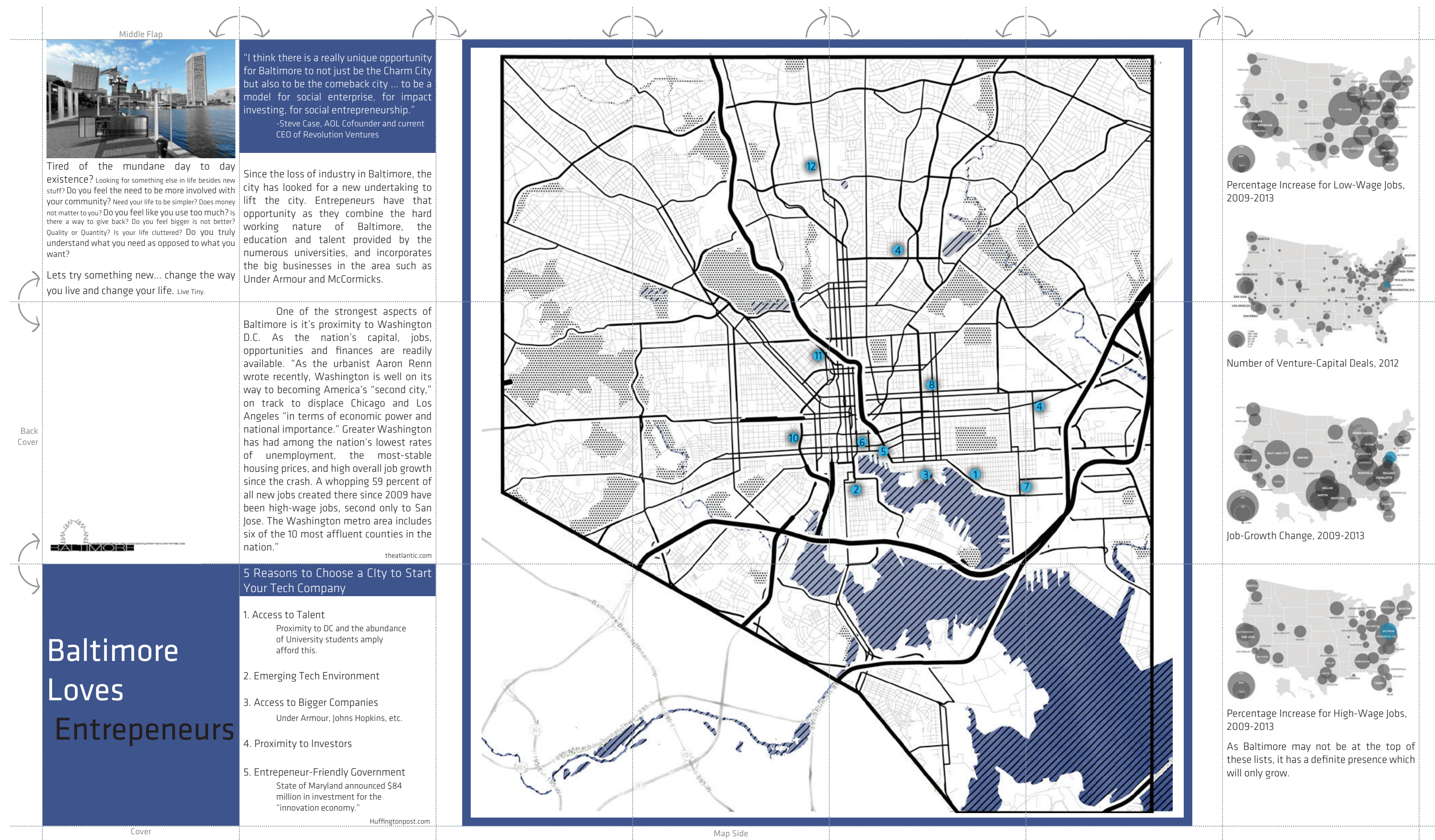




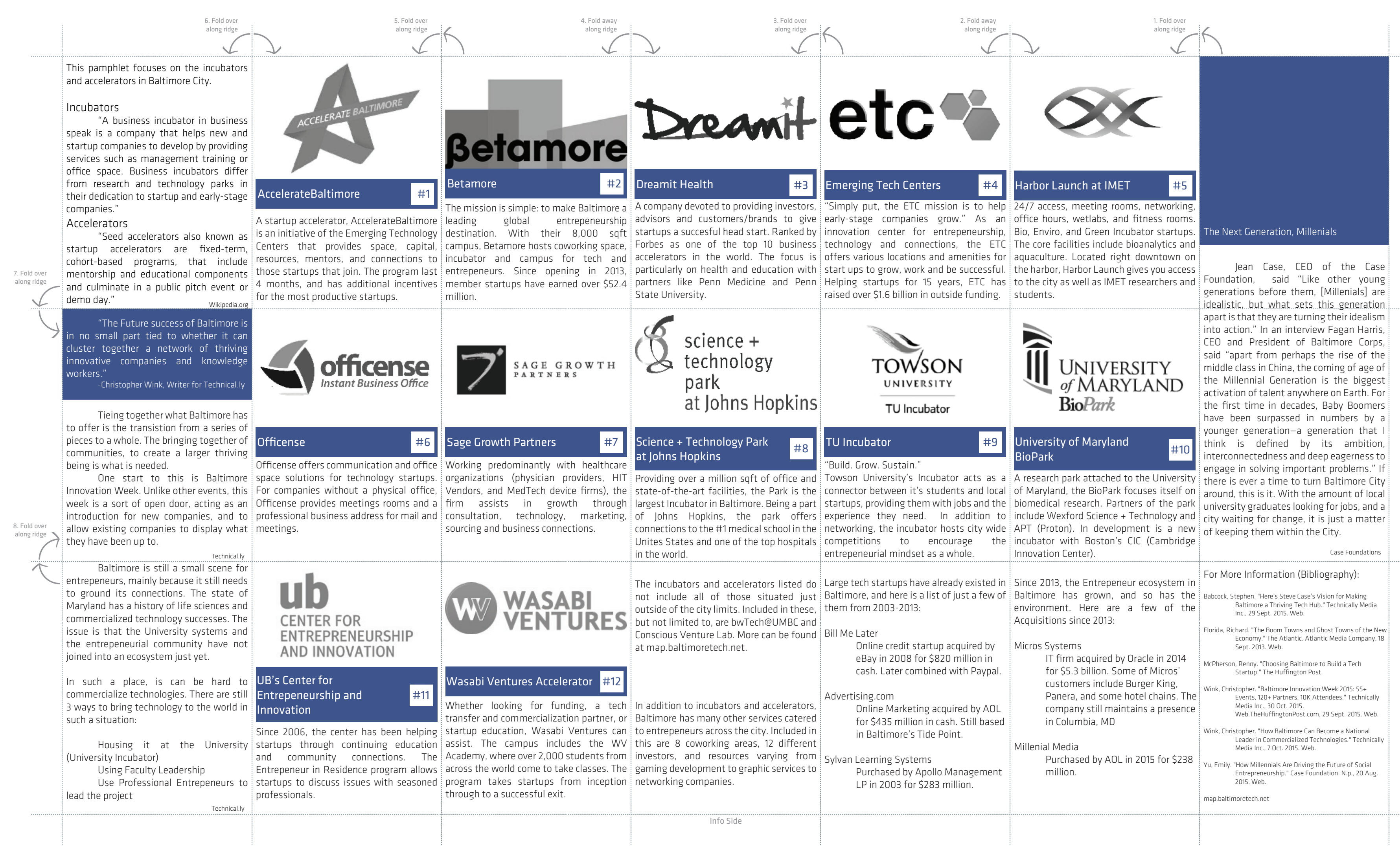

Illustration 21 Entrepeneur Side 2. 
"I think there is a really unique opportunity for Baltimore to not just be the Charm City but also to be the comeback city ... to be a model for social enterprise, for impact investing, for social entrepreneurship."

-Steve Case, AOL Cofounder and current CEO of Revolution Ventures

\section{Entrepeneurs}

Since the loss of industry and the manufacturing base, Baltimore has sought new undertakings to economically lift the city. Entrepeneurs have that opportunity as they benefit from the hard working nature of Baltimore, the education and talent provided by the numerous universities, and the presence of big businesses in areas such as Under Armour and McCormicks. One of the strongest aspects of Baltimore is it's proximity to Washington D.C. As the nation's capital, jobs, opportunities and finances are readily available. "As the urbanist Aaron Renn wrote recently, Washington is well on its way to becoming America's "second city," on track to displace Chicago and Los Angeles "in terms of economic power and national importance." Greater Washington has had among the nation's lowest rates of unemployment, the most-stable housing prices, and high overall job growth since the 2008 financial crash. A whopping 59 percent of all new jobs created there since 2009 have been high-wage jobs, second only to San Jose. The Washington metro area includes six of the ten most affluent counties in the nation."12

Baltimore is still a relatively small scene for entrepeneurs, mainly because it still needs to expand its connections. The state of Maryland has a proven history in life sciences research and commercialized technology successes. The issue is that the University systems and the entrepeneurial community have not yet collaborated in joint programs and projects. ${ }^{13}$

12. Florida, Richard. "The Boom Towns and Ghost Towns of the New Economy."

13. Wink, Christopher. "How Baltimore Can Become a National Leader in Commercialized Technologies." 
Large tech startups have already found

success in Baltimore. Included on this list,

dating from 2003-2013:

Bill Me Later

Online credit startup acquired by eBay in 2008 for $\$ 820$ million in cash. Later combined with Paypal.

Advertising.com

Online Marketing acquired by AOL for $\$ 435$ million in cash. Still based in Baltimore's Tide Point.

Sylvan Learning Systems

Purchased by Apollo Management

LP in 2003 for \$283 million.

Information from Huffingtonpost.com
5 Reasons to Choose a City to Start Your

Tech Company

1. Access to Talent

Proximity to DC and the abundance of University students amply afford this.

2. Emerging Tech Environment

3. Access to Bigger Companies

Under Armour, Johns Hopkins, etc.

4. Proximity to Investors

5. Entrepeneur-Friendly Government

State of Maryland announced \$84

million in investment for the innovation economy."

Tieing together what Baltimore has to offer provides a transition from a series of fragmented pieces to a unified whole. The bringing together of communities, to create a larger thriving network is what is needed. A promising new endeavor is presented by Baltimore Innovation Week. Unlike other events, this week is a sort of open house, providing an introduction to new companies, and allowing existing companies to display what they have been developing. ${ }^{14}$ With 10,000 attendees and 55 events, this was no small gathering; however, overall they lacked a driving aspect: to unify the community. Universities, a large sponsor of entrepeneurial work, were not present. An event still in its infancy, can have large potential for future years to influence the growth of Baltimore. If there is ever a time to turn Baltimore City around, this is it. With the amount of local university graduates looking for jobs, and a city waiting for change, it is just a matter of keeping them within the City by providing opportunities. 

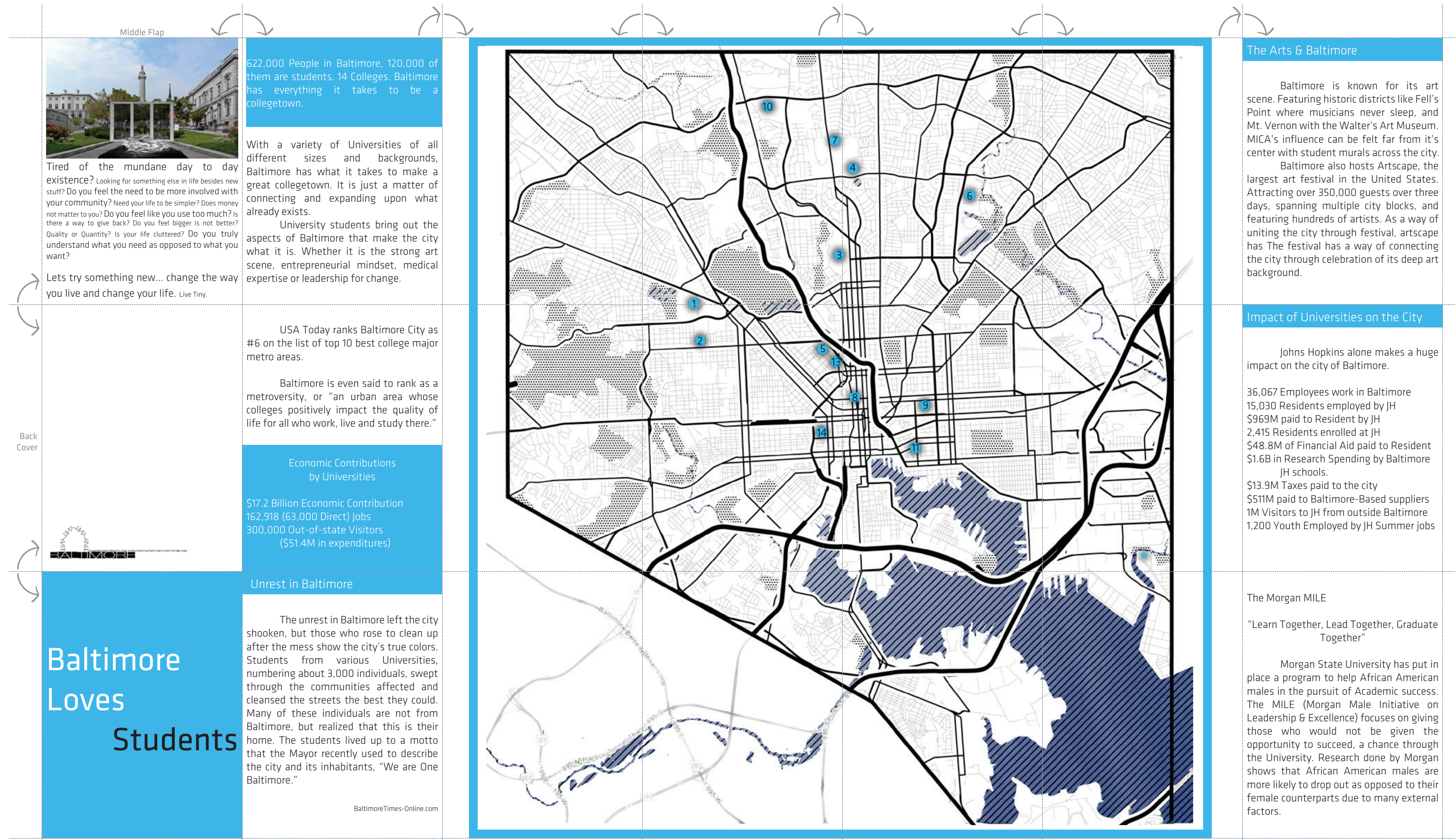

Illustration 22 University Students Packet Side 1. 


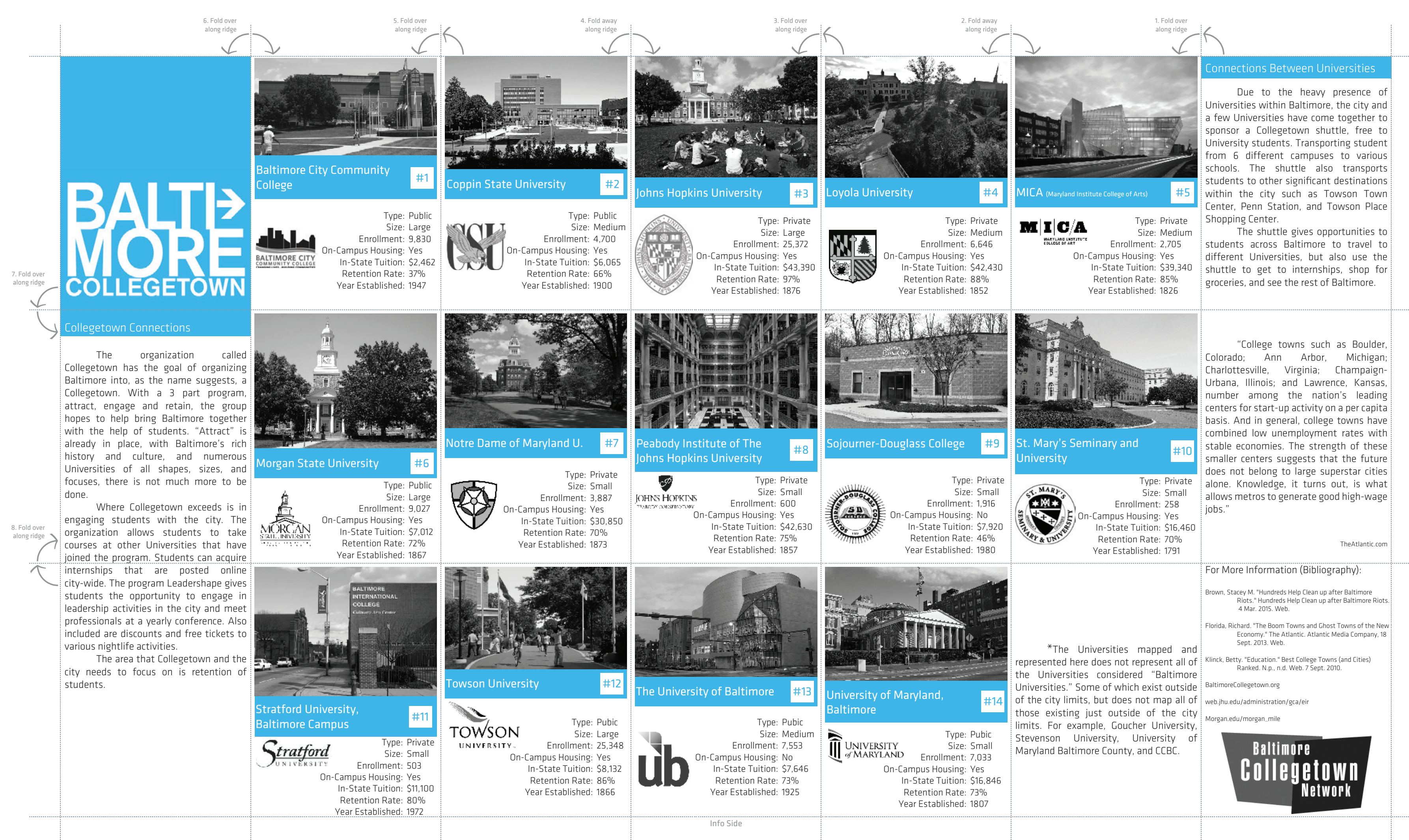


"College towns... number among the nation's leading centers for start-up activity on a per capita basis. And in general, college towns have combined low unemployment rates with stable economies. Knowledge, it turns out, is what allows metros to generate good highwage jobs."

-TheAtlantic.com

\section{University Students}

Of the 622,000 People in Baltimore, 120,000 are students attending 14 Colleges. Baltimore has everything it takes to be a collegetown.

\section{Connections Between Universities}

Due to the heavy presence of Universities within Baltimore, the city and a few Universities have come together to sponsor a Collegetown shuttle, free to University students, transporting student from 6 different campuses to various schools. The shuttle also transports students to other significant destinations within the city such as Towson Town Center, Penn Station, and Towson Place Shopping Center. The shuttle gives opportunities to students across Baltimore to travel to different Universities, but also use the shuttle to get to internships, shop for groceries, and see the other parts of the city.

\section{The Morgan MILE}

"Learn Together, Lead Together, Graduate Together"

Morgan State University has put in place a program to help African American males in the pursuit of Academic success. The MILE (Morgan Male Initiative on Leadership \& Excellence) focuses on giving those who would not be given the opportunity to succeed, a chance through this University initiative. Research done by Morgan shows that African American males are more likely to drop out as opposed to their female counterparts due to many external factors. 


\title{
Unrest in Baltimore
}

The unrest in Baltimore left the city shaken, but those who rose to clean up after the mess show the city's true colors. Students from various Universities, numbering about 3,000 individuals, swept through the affected communities and cleaned the streets. The students lived up to a motto that the Mayor recently used to describe the city and its inhabitants, "We are One Baltimore."15

\author{
Impact of Universities on the City ${ }^{16}$ \\ Johns Hopkins alone makes a huge impact on the city of Baltimore. \\ 36,067 Employees work in Baltimore at Johns Hopkins \\ 15,030 Residents employed by JH \\ $\$ 969 M$ paid to Residents by JH \\ 2,415 Residents enrolled at JH \\ \$48.8M of Financial Aid paid to Residents \\ $\$ 1.6 \mathrm{~B}$ in Research Spending by Baltimore JH schools. \\ \$13.9M Taxes paid to the city \\ $\$ 511 \mathrm{M}$ paid to Baltimore-Based suppliers \\ $1 \mathrm{M}$ Visitors to JH from outside Baltimore annually \\ 1,200 Youth Employed by JH Summer jobs
}

USA Today ranks Baltimore City \#6 on the list of top 10 best college major metro areas. Baltimore ranks as a metroversity, or "an urban area whose colleges positively impact the quality of life for all who work, live and study there."

\footnotetext{
15. Brown, Stacey M. “Hundreds Help Clean up after Baltimore Riots."

16. "The Impact of Johns Hopkins in Baltimore City." The Journal of Blacks in Higher Education
} 


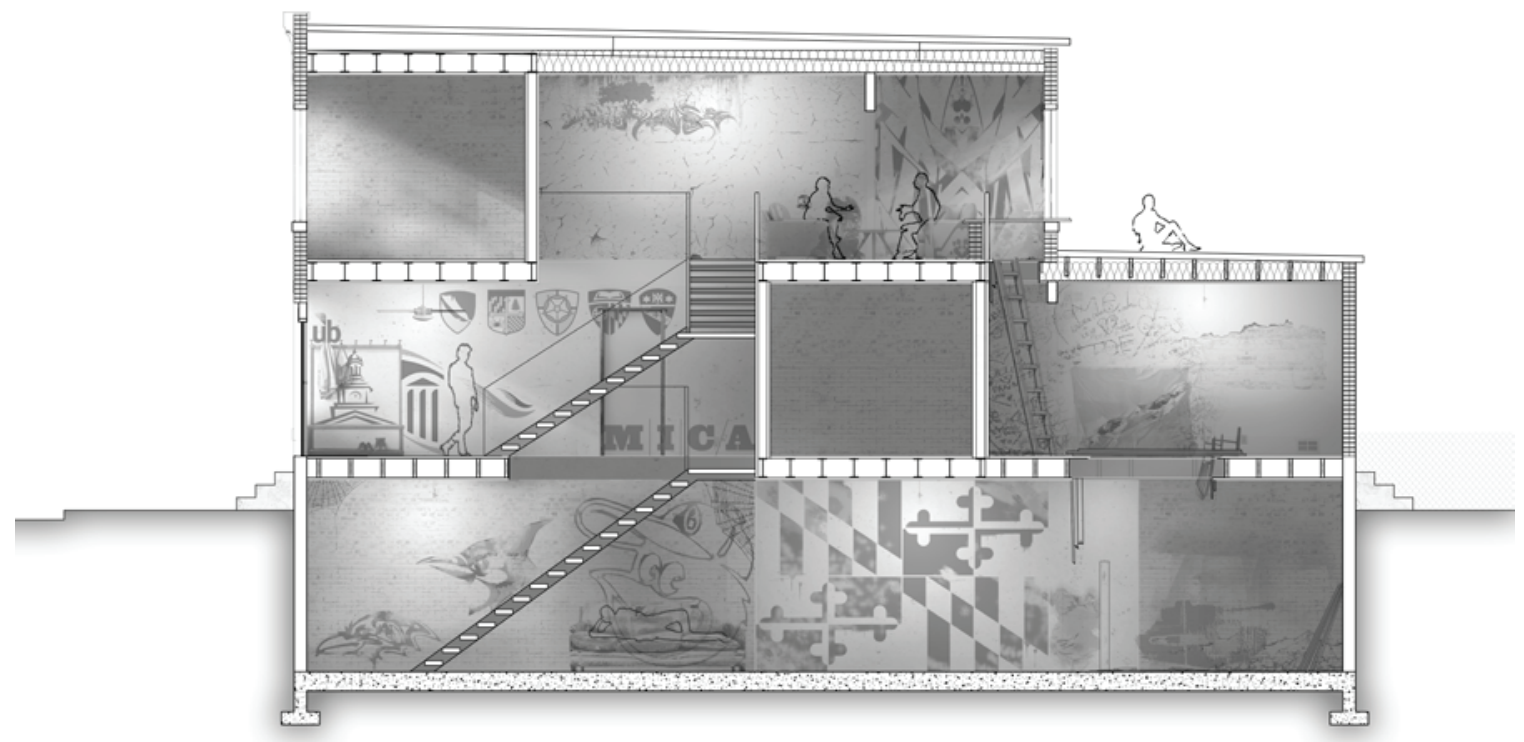

\section{Illustration 24 Student housing concept section.}

How can a home meant for one family be converted into a home for many?

What if the home has been gutted, and there are no floors or partitions remaining in the home? 

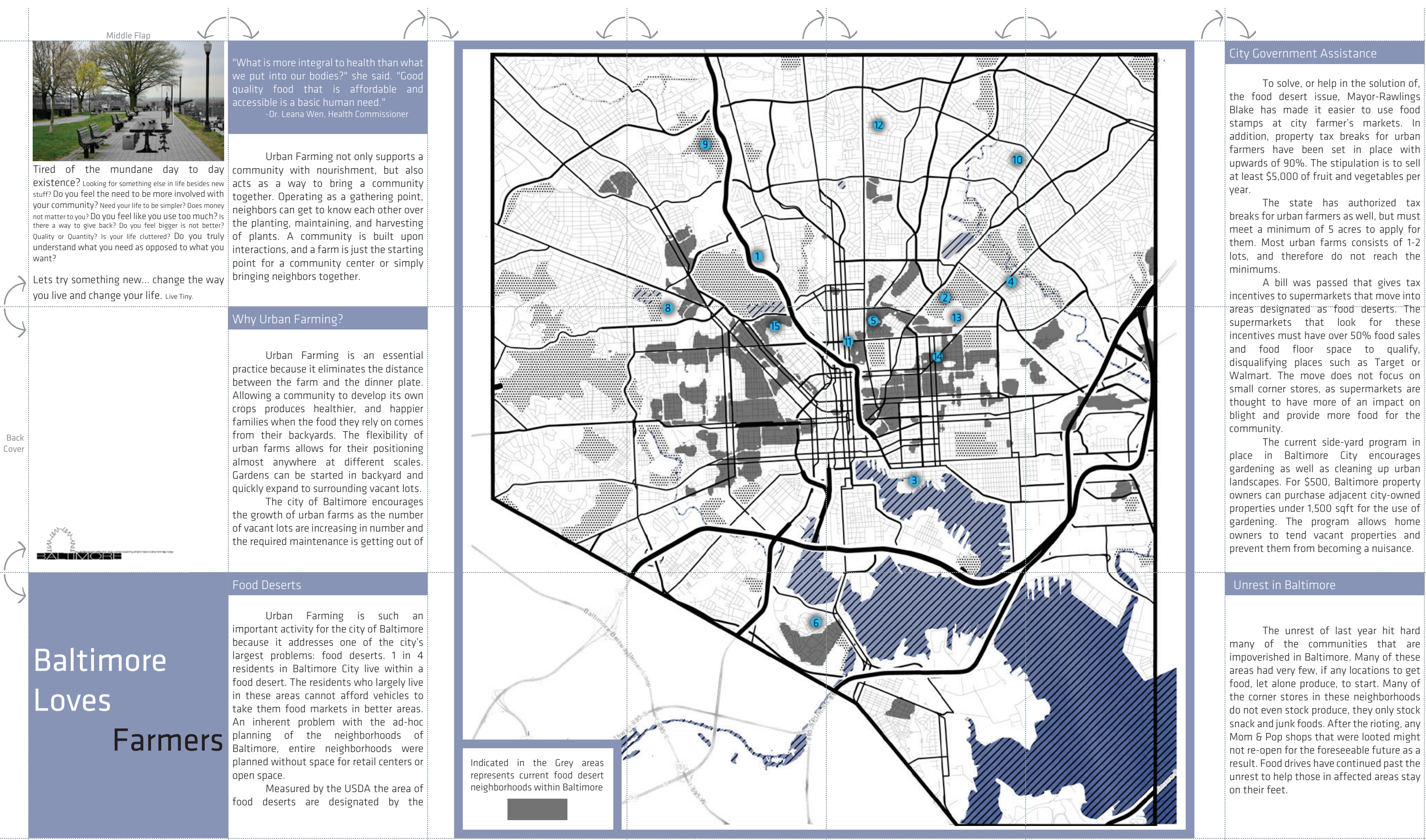


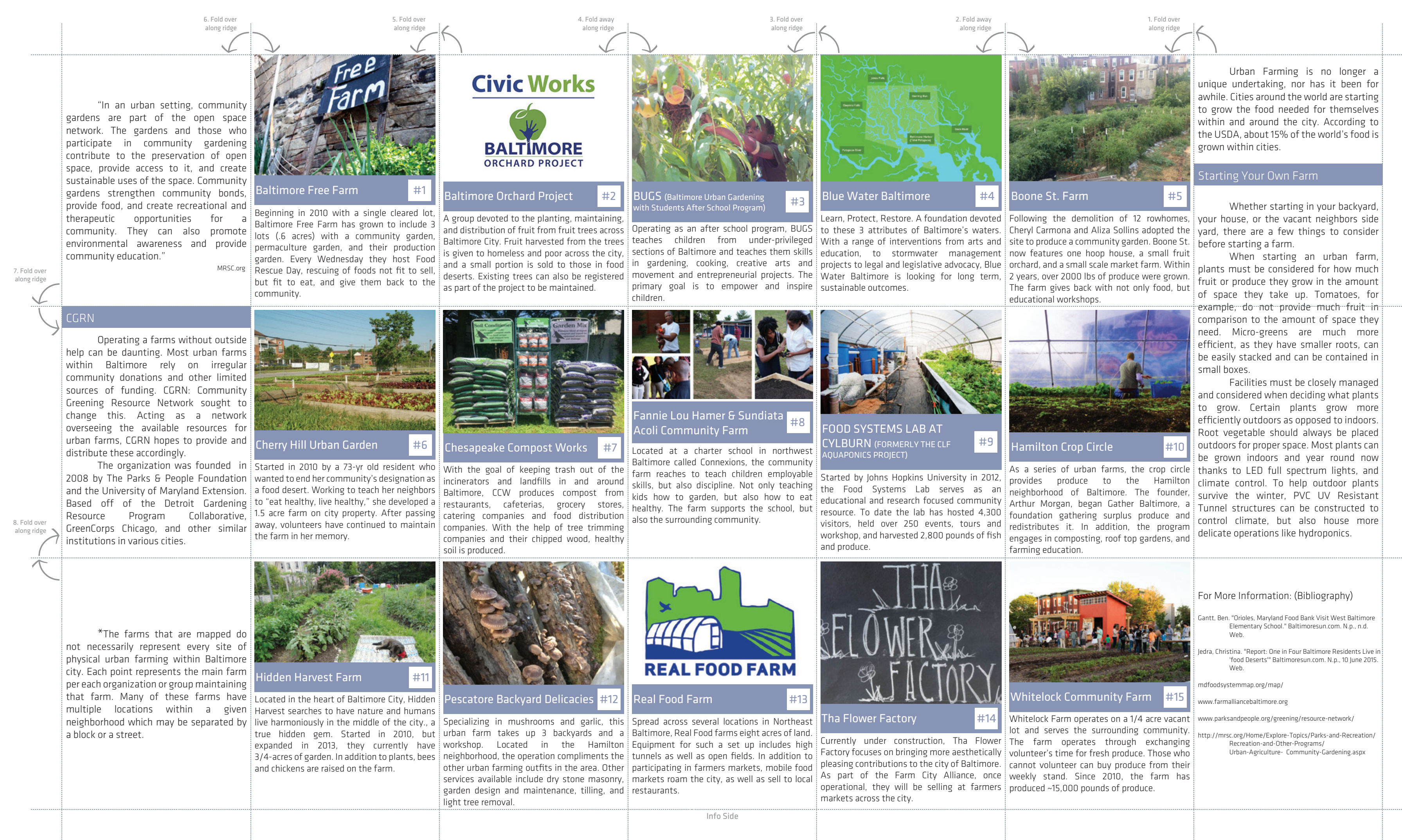

Illustration 26 Urban Farmers Packet Side 2. 
"What is more integral to health than what we put into our bodies?" she said. "Good quality food that is affordable and accessible is a basic human need."

-Dr. Leana Wen, Health Commissioner

\section{Urban Farmers}

Urban Farming not only supports a community with nourishment, but also acts as a way to bring a community together. Operating as a gathering point, neighbors can get to know each other over the planting, maintaining, and harvesting of plants. A community is built upon interactions, and a farm is just the starting point for a community that brings neighbors together.

Urban Farming is an essential practice because it eliminates the distance between the farm and the dinner plate, which is especially important in food deserts. Allowing a community to develop its own crops produces healthier, and happier families when the food they rely on comes from their backyards. The flexibility of urban farms allows for their positioning almost anywhere and at different scales. Gardens can be started in backyard and quickly expand to surrounding vacant lots. The city of Baltimore encourages the growth of urban farms as the number of vacant lots are increasing in number and maintenance is unmanageable. The growth of a farm becomes a conversion of a grass patch to a community tool.

"In an urban setting, community gardens are part of the open space network. The gardens and those who participate in community gardening contribute to the preservation of open space, provide access to it, and create sustainable uses of the space. Community gardens strengthen community bonds, provide food, and create recreational and therapeutic opportunities for a community. They can also promote environmental awareness and provide community education."17 


\section{City Government Assistance}

To alleviate the problem of food deserts, Mayor-Rawlings Blake has made it easier to use food stamps at city farmer's markets. In addition, property tax breaks for urban farmers have been set up to $90 \%$. The stipulation requires a minimum yearly sale of $\$ 5,000$ of fruit and vegetables.

The state has authorized tax breaks for urban farm as well, but these must meet a minimum of 5 production acres to qualify. Most urban farms consists of 1-2 lots, and therefore do not meet the minimums. ${ }^{18}$

A bill was passed that gives tax incentives to supermarkets that move into areas designated as food deserts. The supermarkets that look for these incentives must have over $50 \%$ food sales and food floor space to qualify, disqualifying businesses such as Target and Walmart. The bill does not focus on small corner stores, as supermarkets are thought to have more of an impact on blight and provide more food for the community. The current side-yard program in place in Baltimore City encourages gardening as well as cleaning up urban landscapes. For $\$ 500$, Baltimore property owners can purchase adjacent city-owned properties under 1,500 sqft for the explicit use of gardening. The program allows home owners to tend vacant properties and prevent them from their decay. ${ }^{19}$

\section{Unrest in Baltimore}

The civic unrest of 2015 was felt by many of the impoverished neighborhoods in Baltimore. Supermarkets are scarce in these areas, with many families relying on corner stores for their meals; however, the corner stores in these neighborhoods are void of produce, and only stock snack and junk foods. As a result of the rioting, many Mom \& Pop

\footnotetext{
17. "Urban Agriculture - Community Gardening." MRSC.

18. Wenger, Yvonne. "Baltimore City Council Approves Tax Credits for Urban Farmers."

19. Willner, Steven J. "In the Wake of the Freddie Gray Events, Does Senate Bill 541 Provide West Baltimore New Hope?" Ground Rules. MSBA.org, 08 June 2015. Web.
} 
shops that were looted are unlikely to re-open in the foreseeable future. Food drives have continued past the unrest to help those in need within the affected areas.

\section{Food Deserts}

Urban Farming is such a promising activity for the city of Baltimore because it addresses one of the city's largest problems: food deserts. Measured by the USDA, food deserts are defined by the distance to the nearest supermarket, set at .5 and 1 mile demarcations. Vehicle availability is also mapped for these areas. One in four residents in Baltimore City live within a food desert. Often, residents who live in these areas cannot afford vehicles to access food markets located in better areas. An inherent problem with the ad-hoc planning and growth of the neighborhoods of Baltimore is that entire neighborhoods were planned without space for retail centers or open spaces. ${ }^{20}$

\section{CGRN (Community Greening Resource Network)}

Operating a farm without outside help can be daunting. Most urban farms within Baltimore rely on irregular community donations and other limited sources of funding. CGRN: Community Greening Resource Network sought to change this. Acting as a network overseeing the available resources for urban farms, CGRN hopes to provide and distribute the available funds accordingly.

The organization was founded in 2008 by The Parks \& People Foundation and the University of Maryland Extension. The Baltimore model is based on the Detroit Cardening

Resource Program Collaborative, GreenCorps Chicago, and other similar institutions in various cities. 


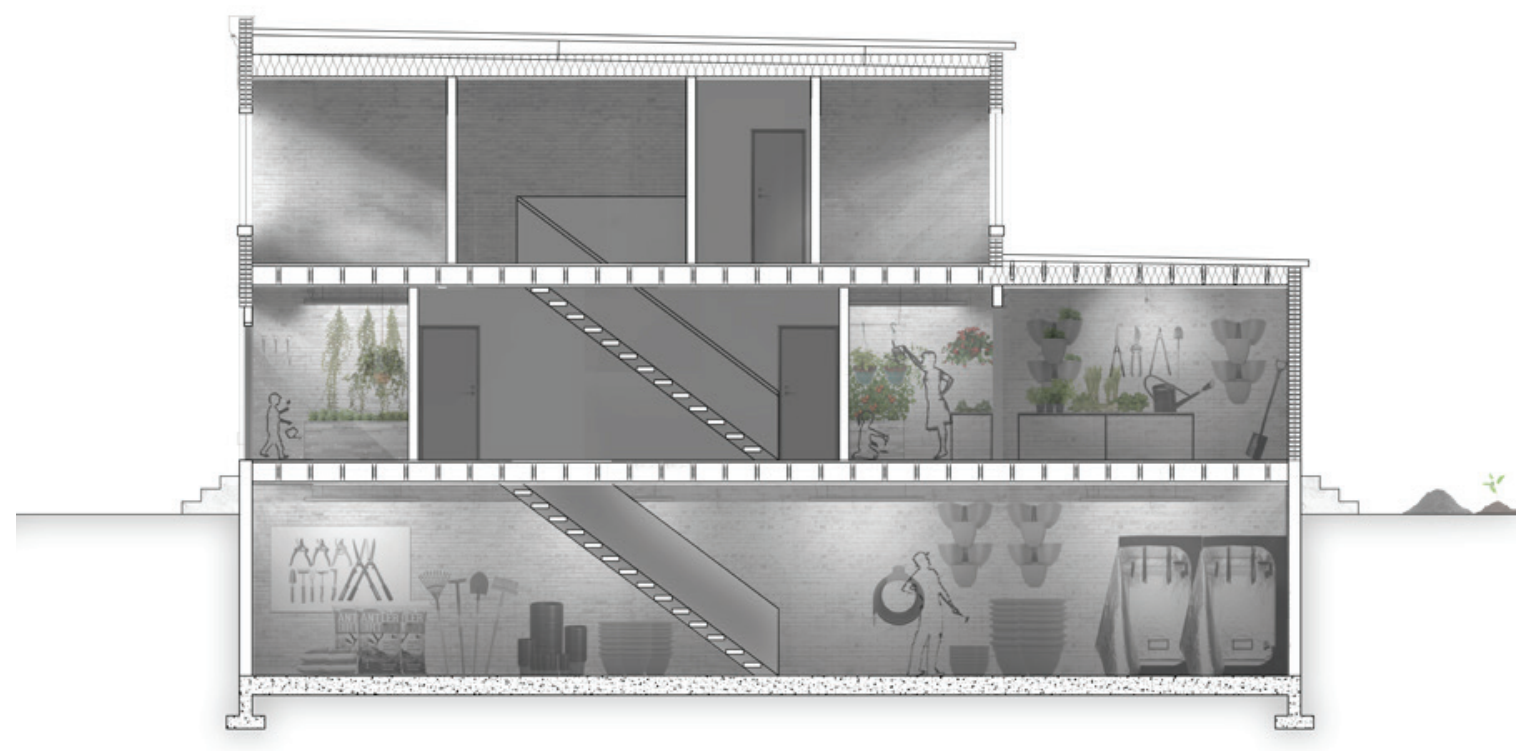

Illustration 27 Urban farming concept section.

Serving the immediate community, or a few adjacent homes, this home can become the centerpiece to a community in need. With the ability to grow food indoors as well as outdoors, the inhabitants can reach out and give back to their neighbors. 

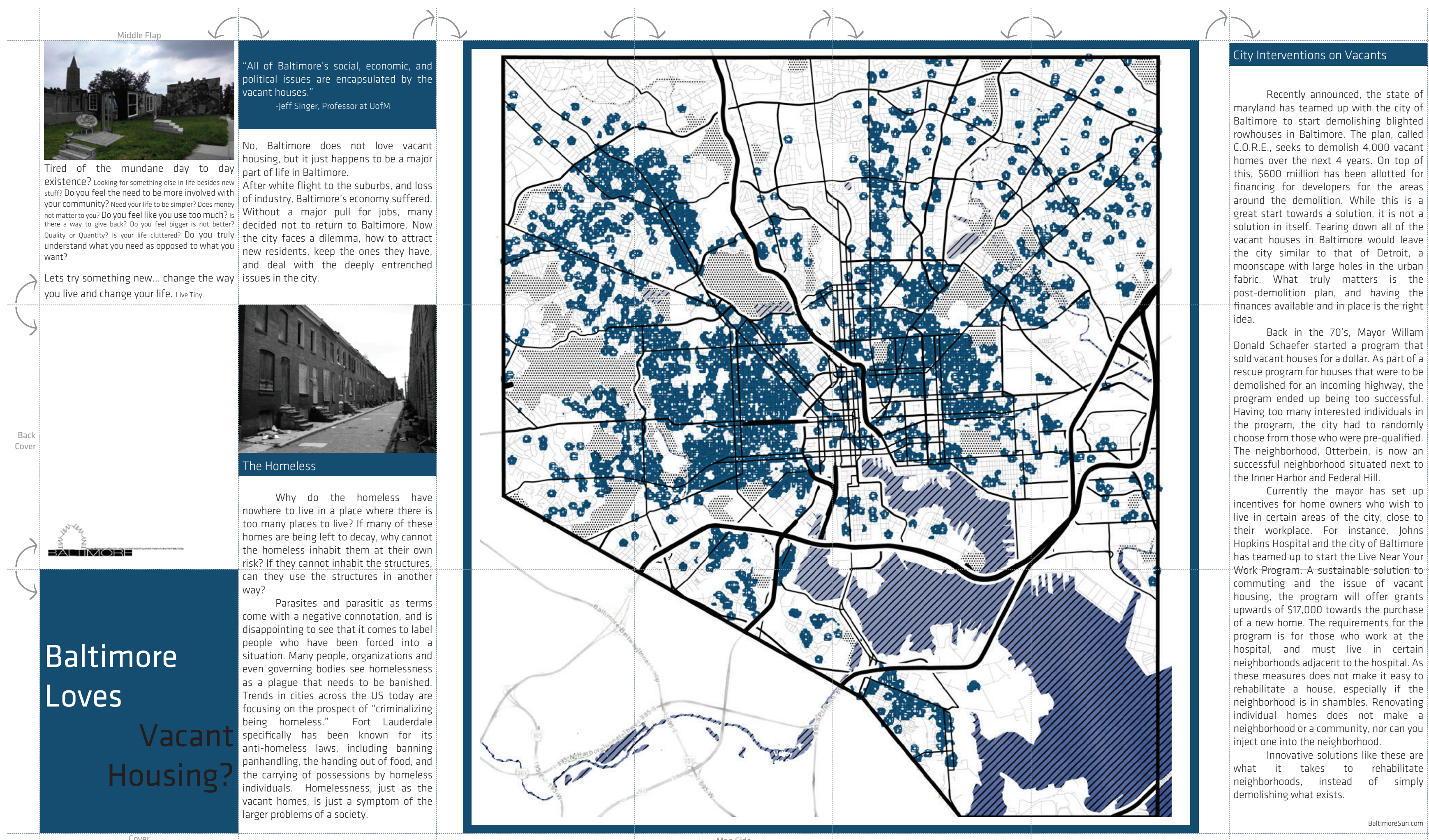


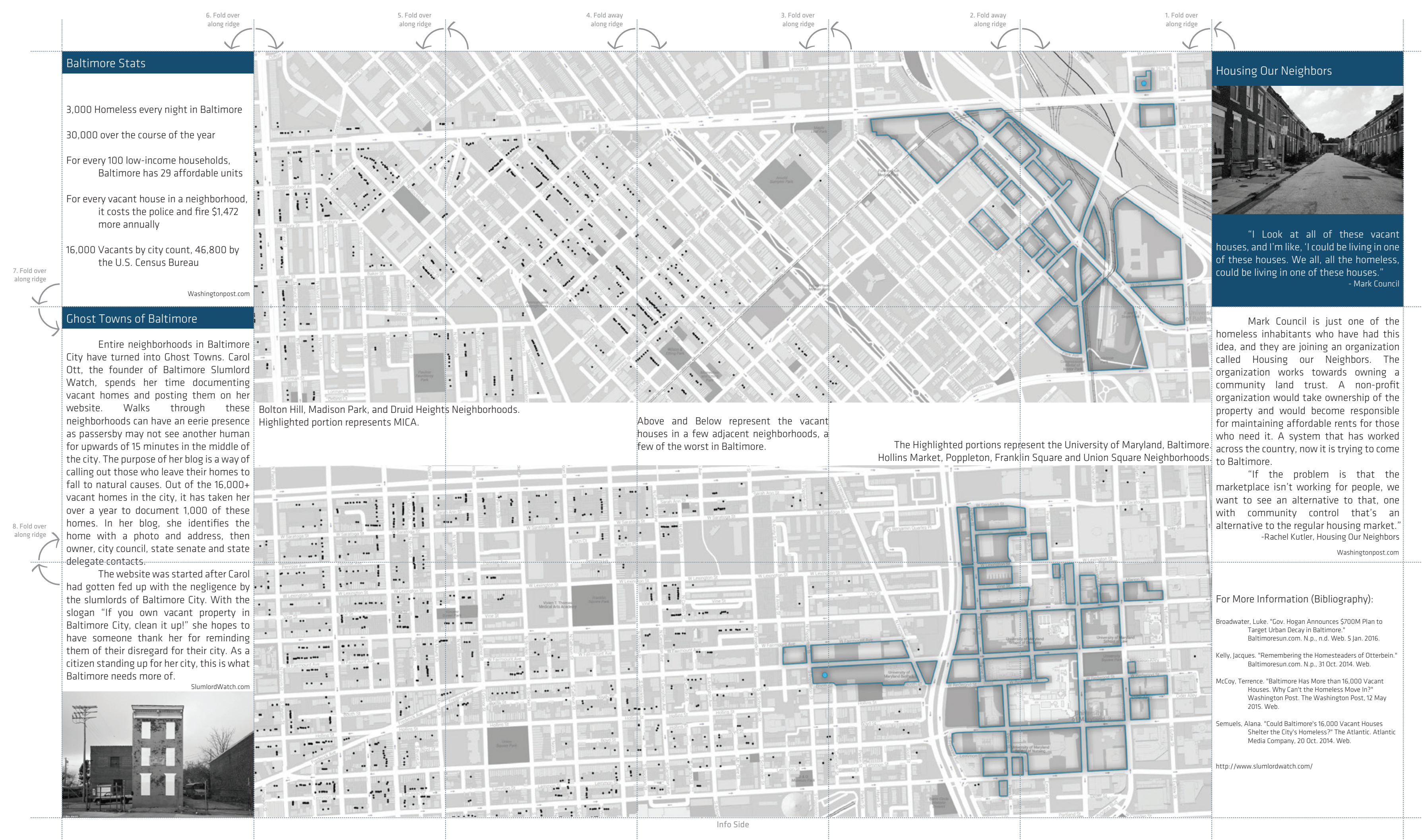

Illustration 29 The Homeless Packet Side 2 . 
"All of Baltimore's social, economic, and political issues are encapsulated by the vacant houses."

-Jeff Singer, Professor at UofM

\section{The Homeless}

Why do the homeless have nowhere to live in a place where there are a large number of vacancies? If many of these homes are being left to decay, why can the homeless not inhabit them; even at their own risk? If they cannot inhabit the structures, can they use the structures in another way?

The terms parasite and parasitic come with negative connotations, and it is disappointing to see that it is used to label people who have been forced into desperate situations. Many people, organizations and governing bodies see homelessness as a plague that needs to be eradicated. Trends in cities across the US today are focusing on the prospect of "criminalizing homelessness."21 Fort Lauderdale specifically has been known for its anti-homeless laws, including banning panhandling, the handing out of food, and the carrying of possessions by homeless individuals. ${ }^{22}$ Homelessness, just as the vacant homes, are symptoms of the larger problems of a struggling society.

\section{City Interventions on Vacants}

The state of Maryland has recently announced that they have teamed up with the city of Baltimore to start demolishing decrepit rowhouses in Baltimore. The plan, called C.O.R.E. (Creating Opportunities for Renewal and Enterprise), seeks to demolish 4,000 vacant homes over the next 4 years. ${ }^{22}$ In addition, $\$ 600$ million has been allotted for the

\footnotetext{
21. Barclay, Eliza. "More Cities Are Making It Illegal To Hand Out Food To The Homeless."

22. Keyes, Scott. "City Makes It Illegal To Sleep In Publc In Effort To Crack Down On The Homeless."
} 
financing of developers active in the areas surrounding the demolition sites. While this is a great start towards a solution, it is not a solution in itself. Tearing down all of the vacant houses in Baltimore would leave the city similar to that of Detroit, a moonscape with large holes in the urban fabric. What truly matters is the post-demolition plan, along with having the finances available and in place.

Back in the 70s, Mayor William Donald Schaefer started a program that sold vacant houses for a dollar in the neighborhood of Otterbein. The homes were in a similar state to those in the neighborhoods discussed in this thesis. The I-95 needed an off ramp to deposit commuters close to the inner harbor, and the neighborhood was under review for the proposal. Rather than sacrificing prime real estate to a highway, the city sold the homes for one dollar. Having too many interested individuals in the program, the city had to randomly choose from those who were pre-qualified. Today, the neighborhood stands as one of the nicest places to live in the downtown core of Baltimore.

Currently the mayor has set up incentives for home owners who wish to live in certain areas of the city, close to their workplace. For instance, Johns Hopkins Hospital and the city of Baltimore has teamed up to start the Live Near Your Work Program. A sustainable solution to commuting and the issue of vacant housing, the program will offer grants upwards of $\$ 17,000$ towards the purchase of a new home. The requirements for the program is in order to qualify those who work at the hospital must live in certain neighborhoods adjacent to the hospital. These funding measures do not make it easy to rehabilitate a house, especially if the neighborhood housing stock is in shambles. Renovating individual homes does not make a community, nor can you create and inject a ready-made community into a neighborhood, but innovative solutions like these are the first steps in the rehabilitation of neighborhoods - and alternative to simply demolishing what exists.

23. "Project C.O.R.E." Department of Housing and Community Development. 


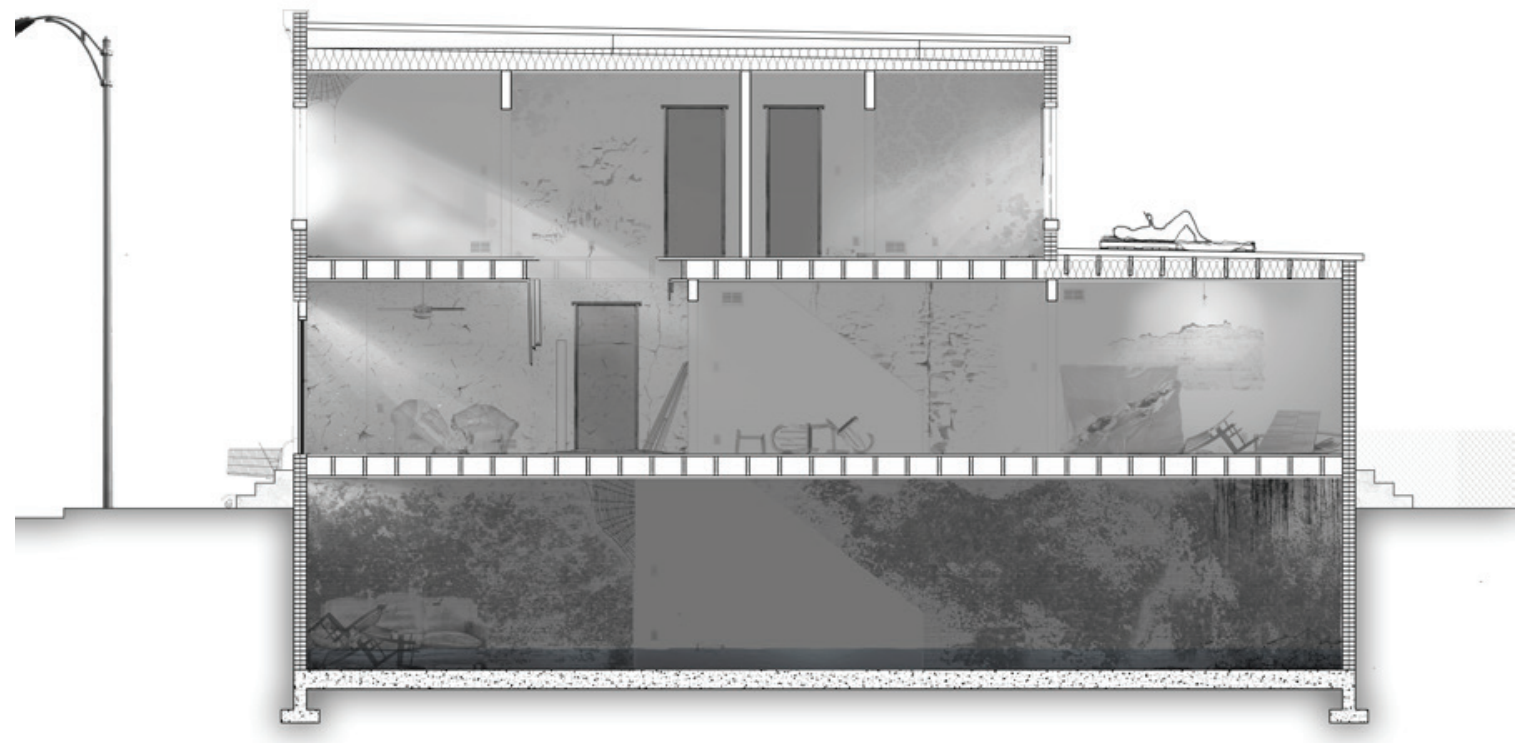

\section{Illustration 30 Homeless concept section.}

Abandoned Rowhomes are left to deteriorate by owners who could not afford the upkeep on a home with depreciating value. Some of these homes are inhabitable to a degree. Could the homeless use them? 


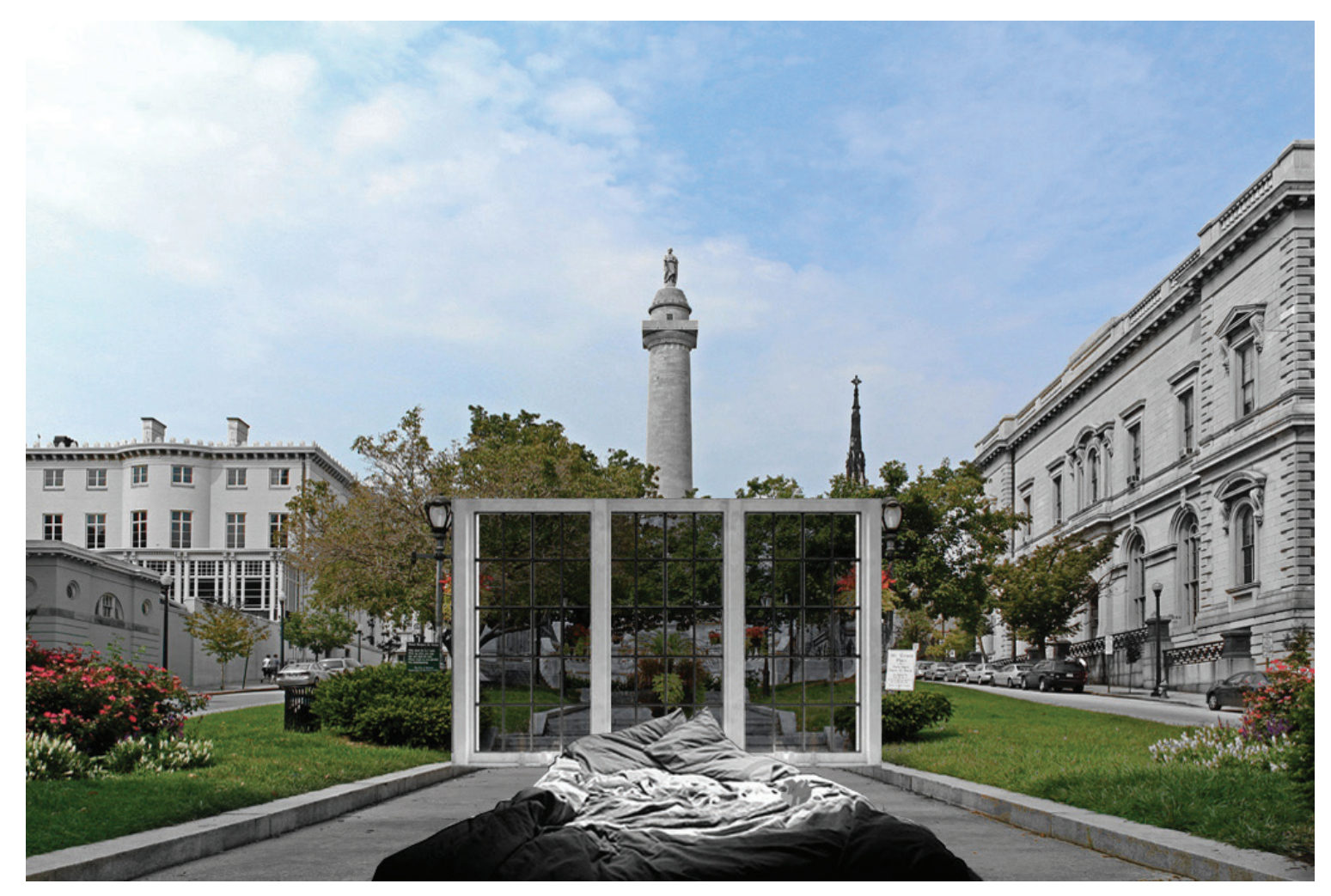

Illustration 31 Tiny visions of Mount Vernon and the Washington Monument. 


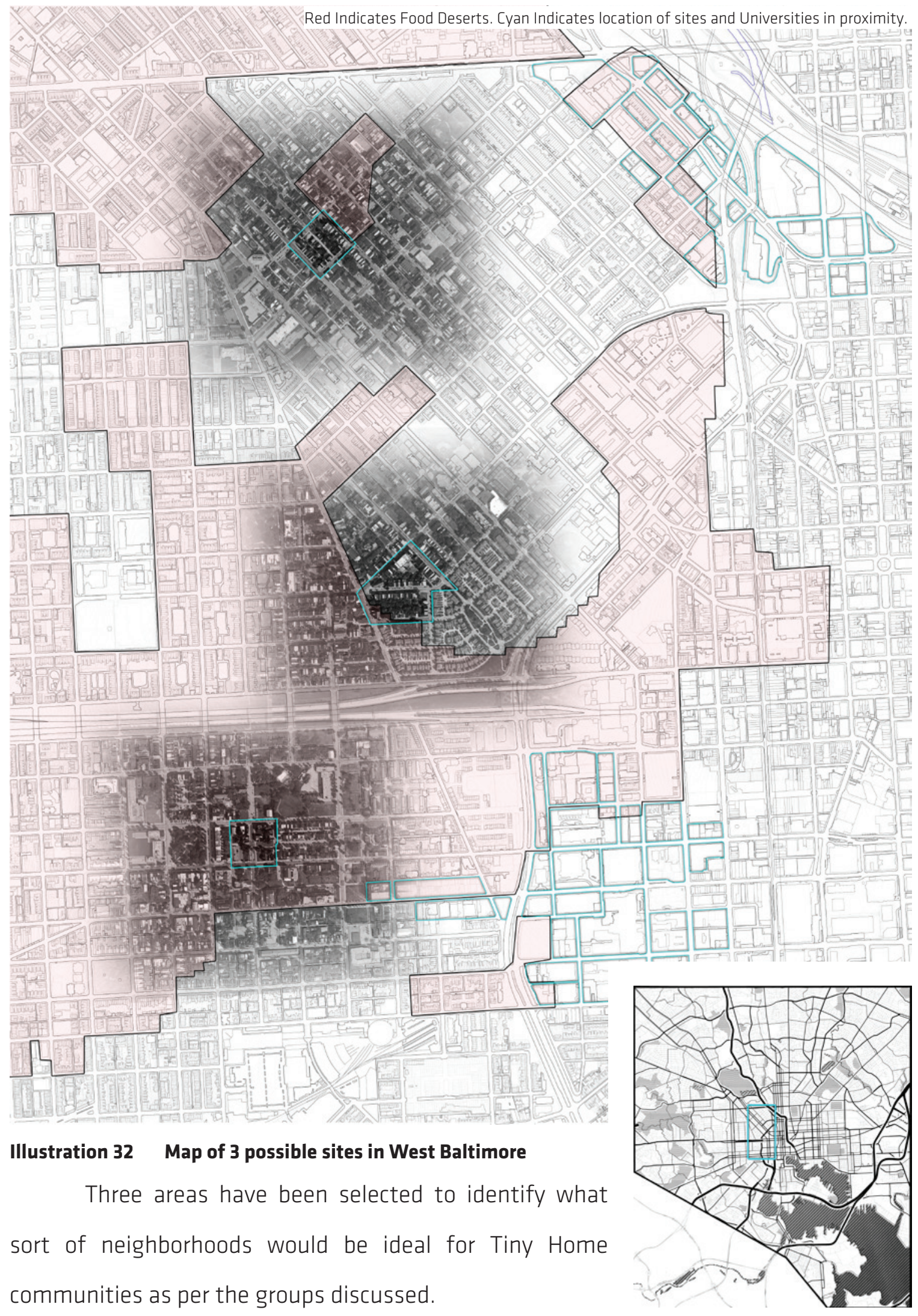




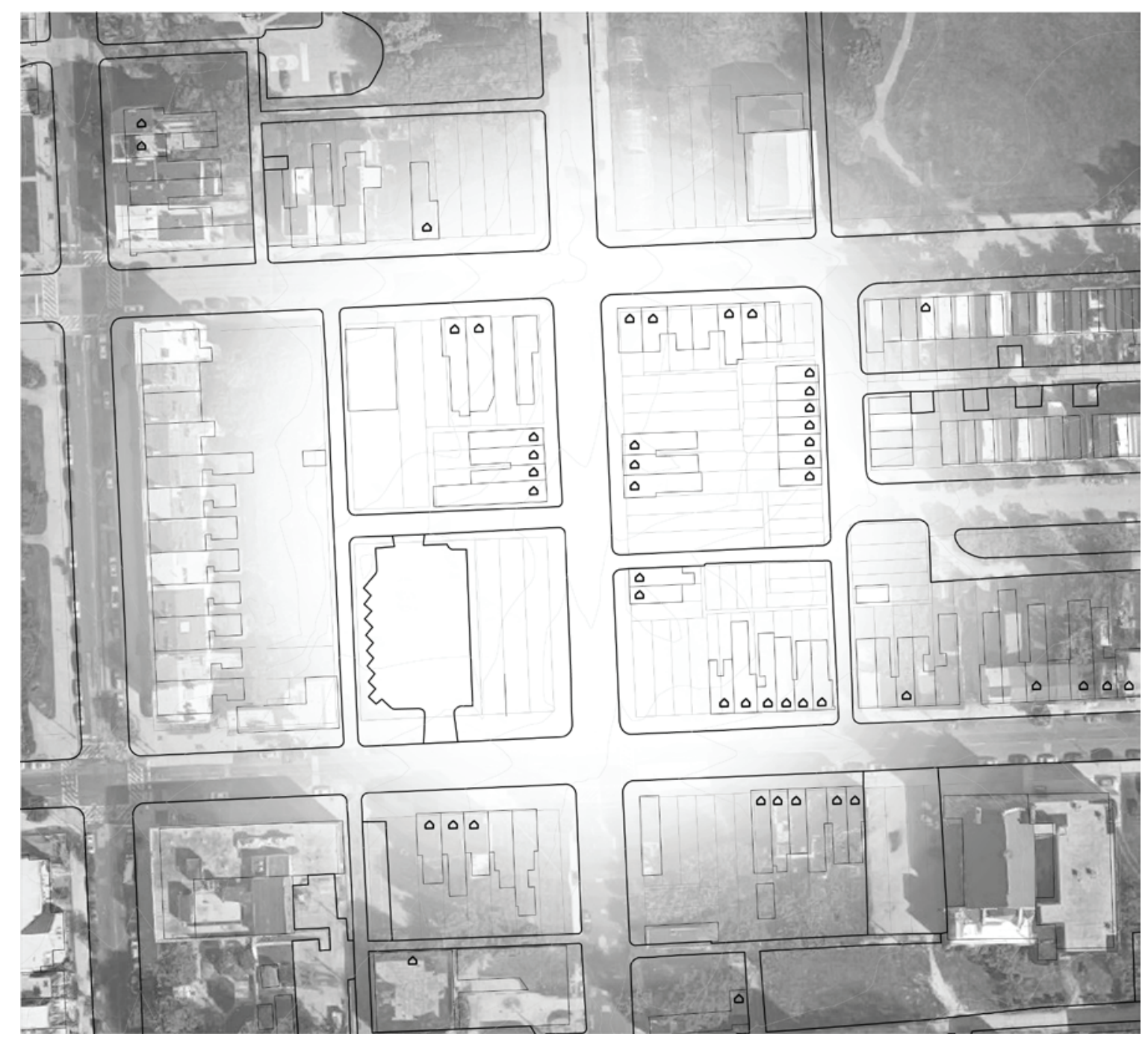

Illustration $33 \quad$ The neighborhood of Franklin Square

Vacancy Rate: 41.3\%
Average Home Price: \$32,045

Median Home Price: $\$ 19,850$ 


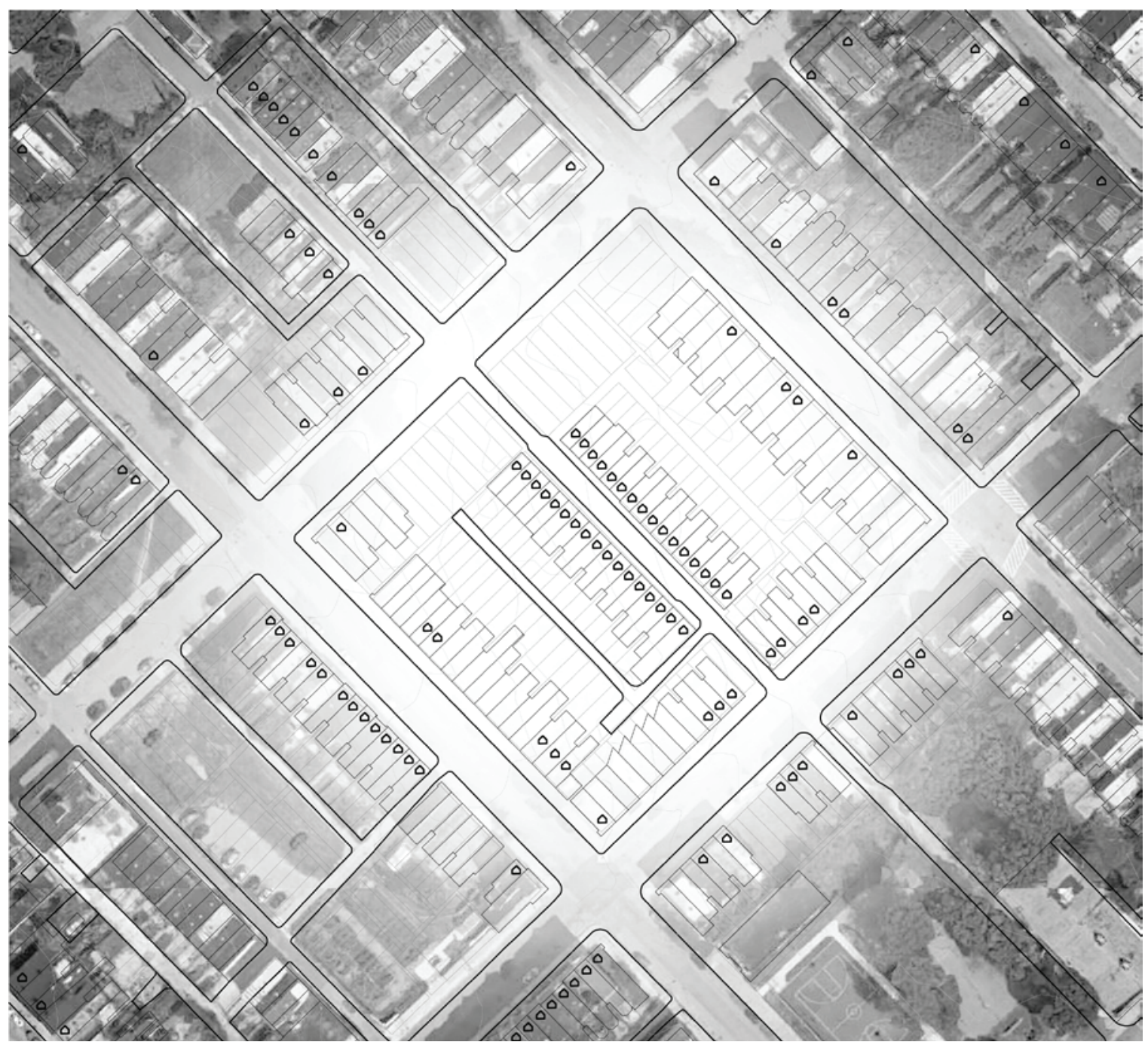

Illustration 34 The neighborhood of Druid Heights.

Vacancy Rate: 45.2\%
Average Home Price: \$35,211 Median Home Price: $\$ 21,000$ 


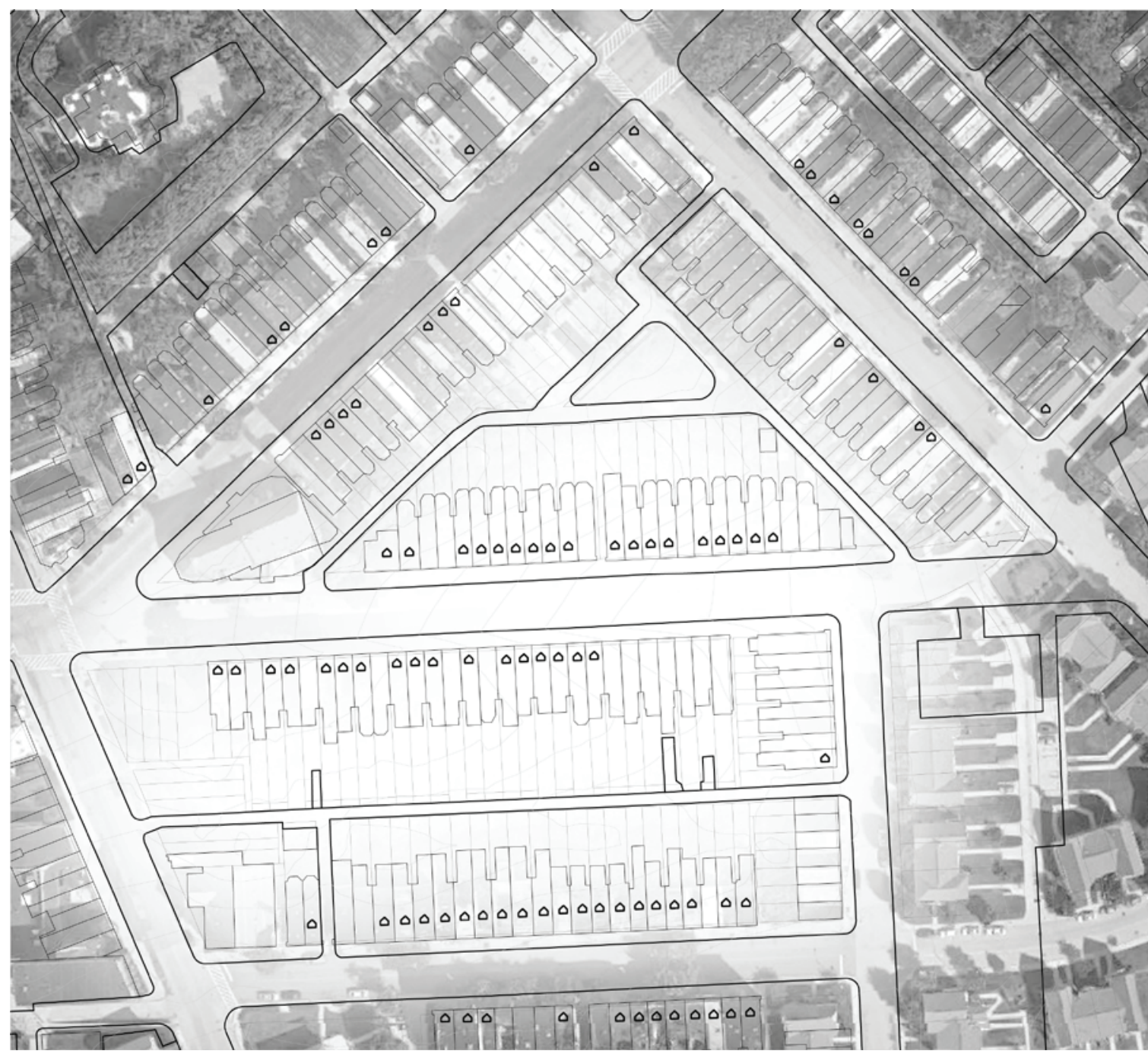

\section{Illustration 35 The neighborhood of Upton.}

Vacancy Rate: 35.9\%
Average Home Price: $\$ 27,810$

Median Home Price: \$16,000 


\section{The Project}

The purpose of this thesis is not to produce construction drawings for Tiny Homes, but rather to demonstrate and document the process of one method of production. In order to achieve this, the manner in which these ideas are produced must be one step removed from reality to keep them from tipping into actuality. To begin, the method of using salvaged materials was selected.

The method of using salvaged materials is quite common for slums, and the homeless; however, the process is also quitecommon for Tiny Home owners. Predominantly, Tiny Homes will not be entirely made of salvaged materials, but a few hybrid objects will be selected as centerpieces or inspirational constructions to set the theme or atmosphere of the home and its transformation. As a physical process, there was the option to physically build a home from materials found around the school or the city. Instead of literally doing so, a series of trips to local thrift stores served as an analogous creative process. The collection of objects were based on a few factors: aesthetic appeal as an object in itself (Swiss Watchbox), the ability to be broken down into more pieces (Toaster), uniqueness (Guy Fawkes Mask), and lightheartedness (Barbies). The exercise allowed the materials to become much more manageable, but also abstract. 


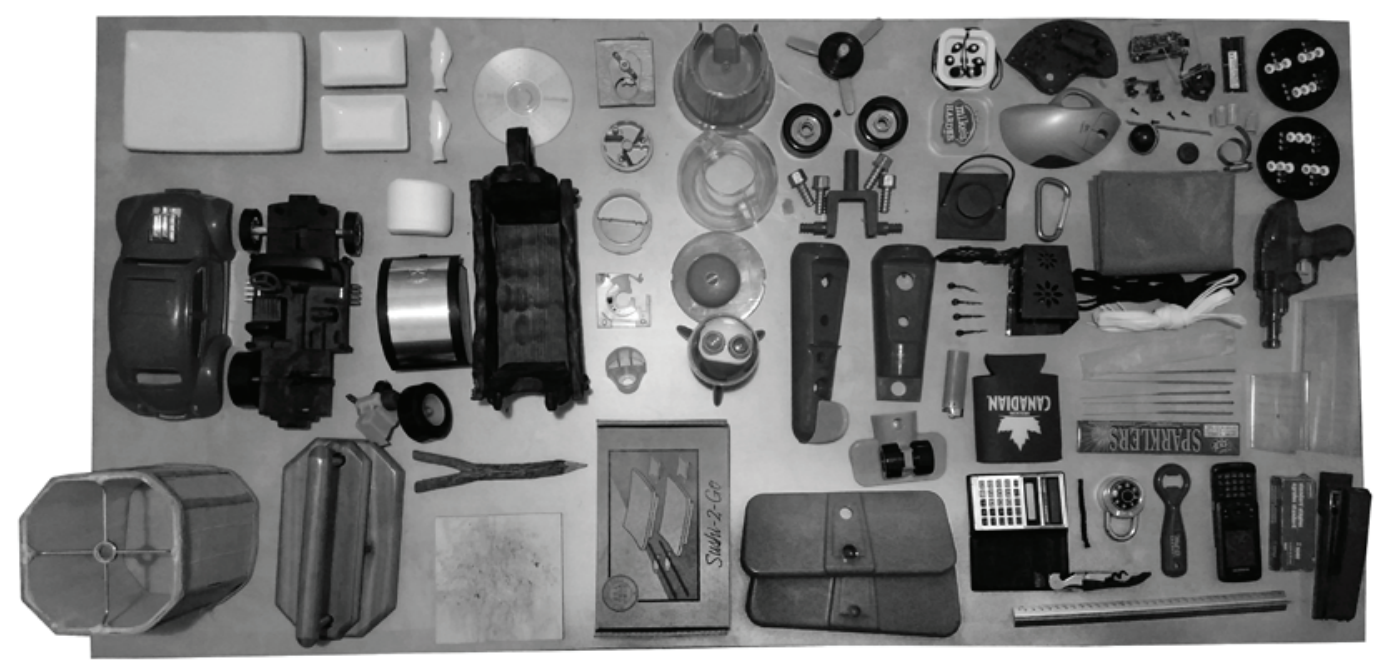

Illustration 36 First collection of found objects.

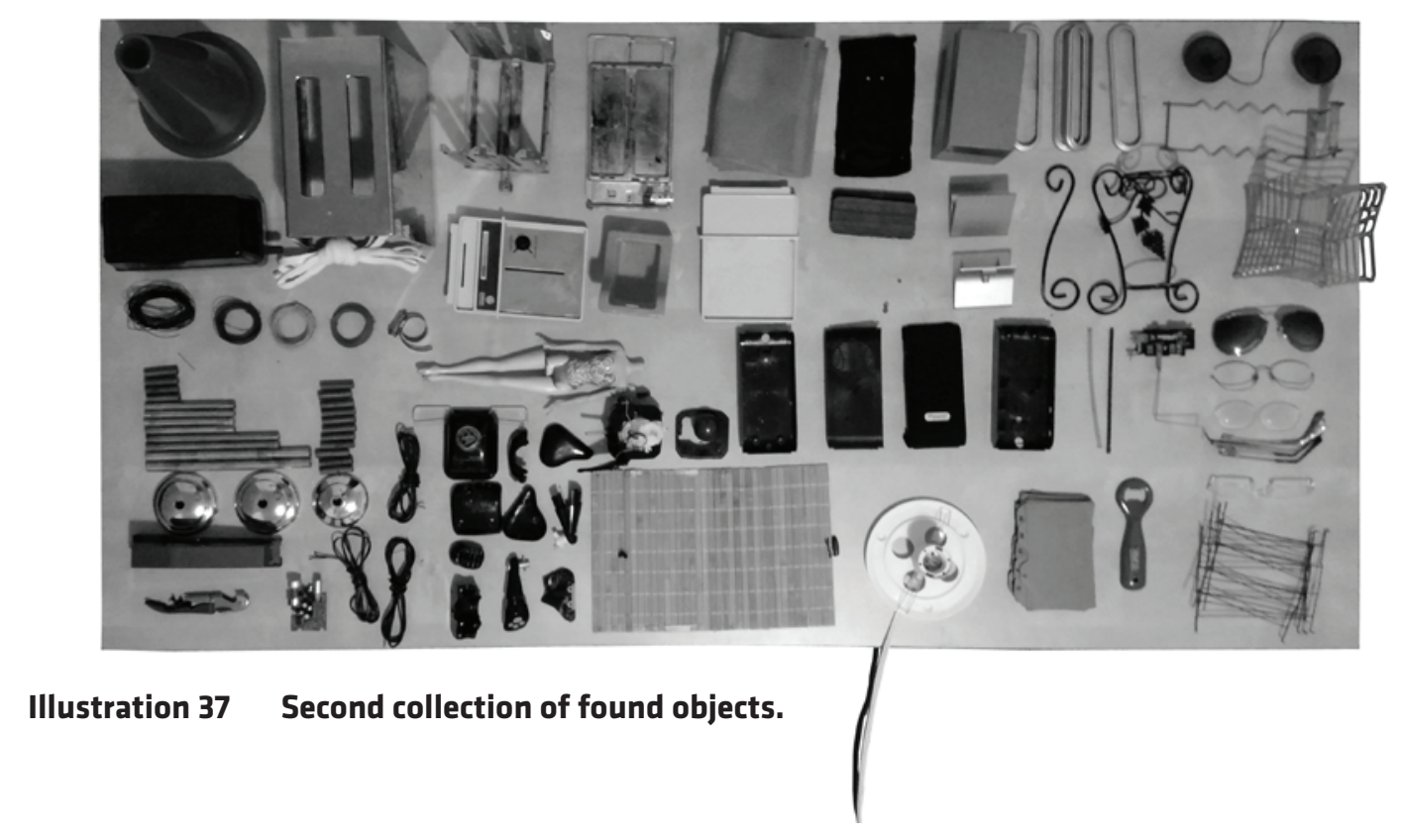




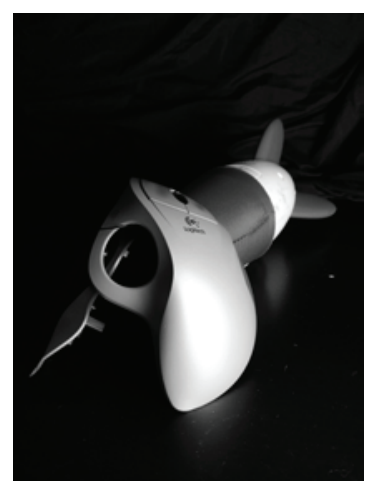

Forms created from

Illustration 38

found objects varying

in scale and complexity.
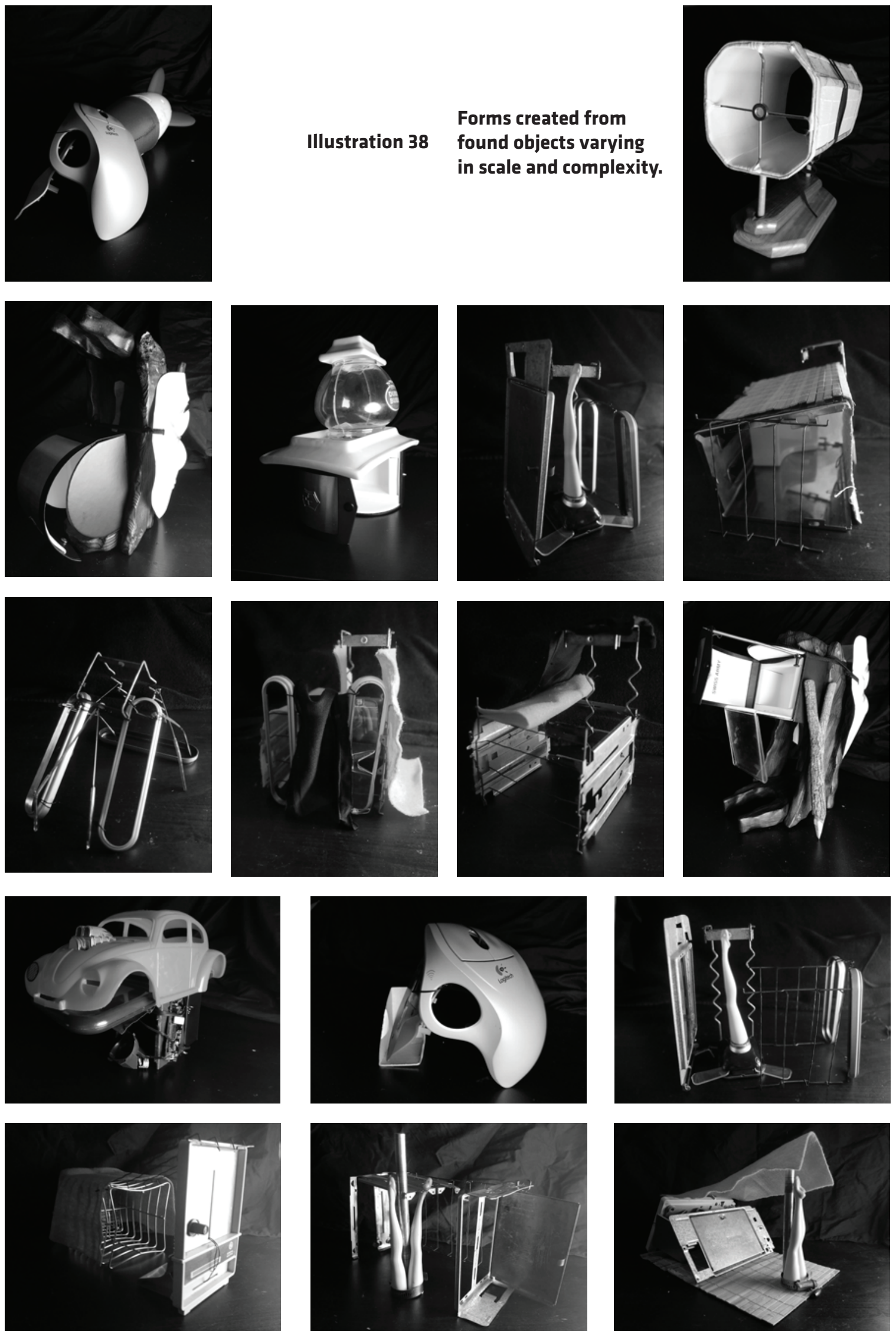

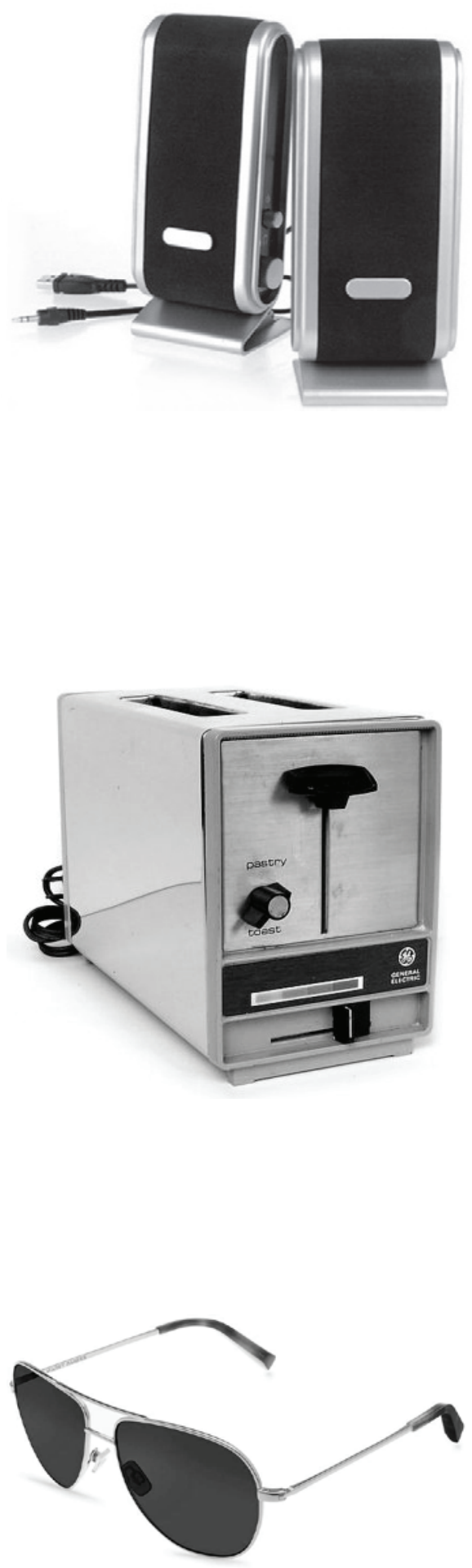

Illustration 39 Objects used in study. 

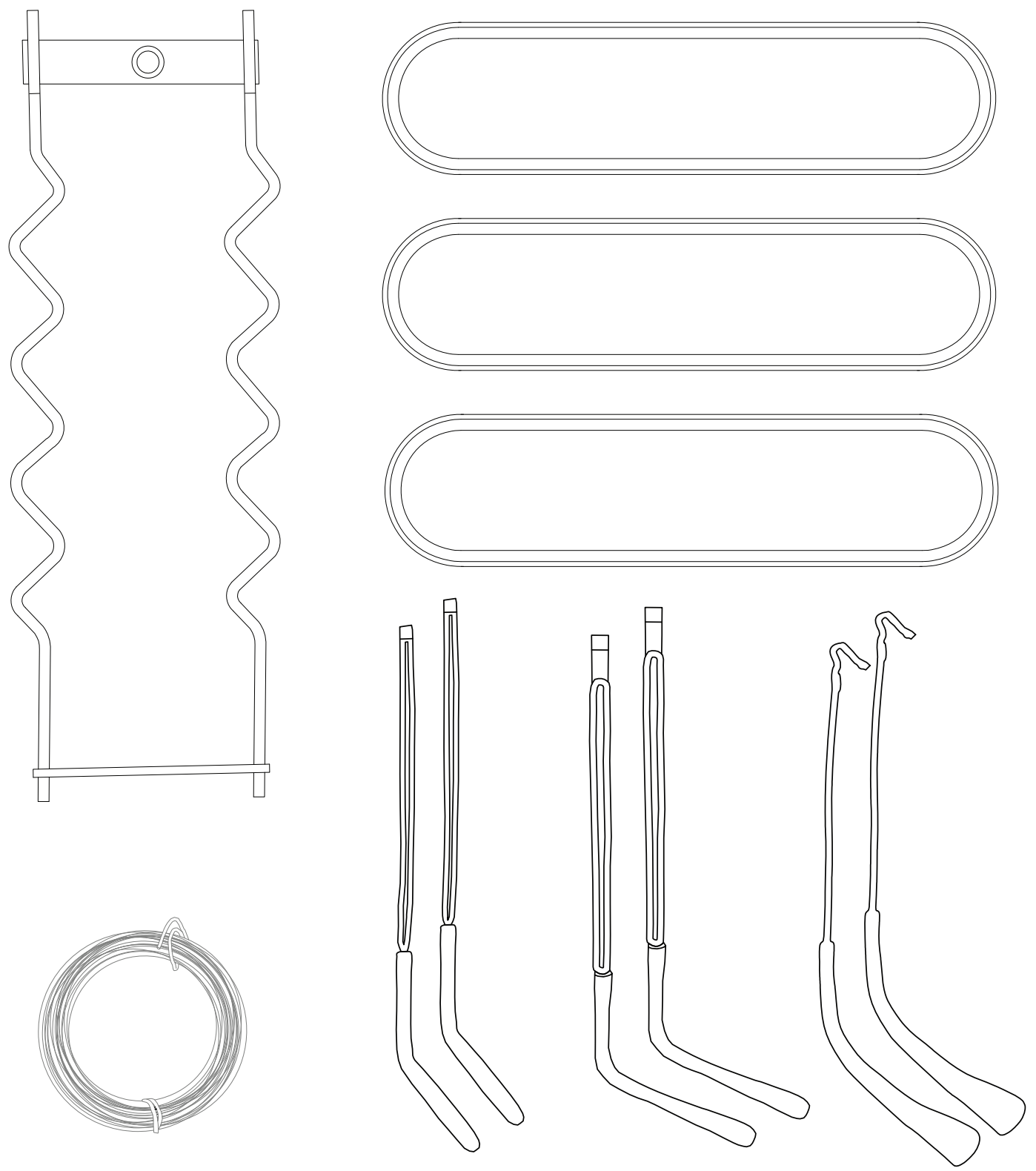

Illustration 40 Plan drawing of components used including sunglasses arms, toaster pull, and speaker frames. 

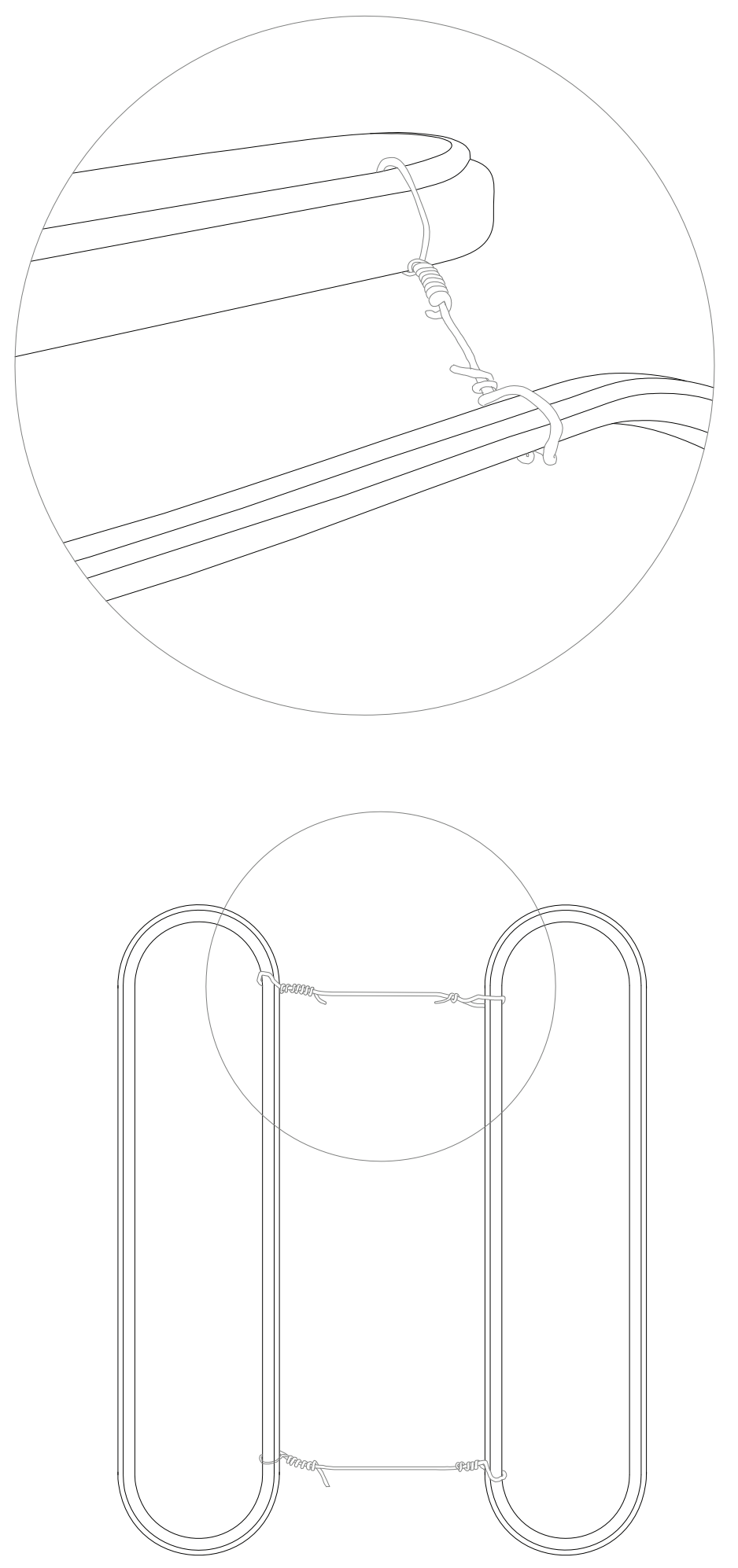

Illustration 41 Operation of tieing speaker frames together using wire. 

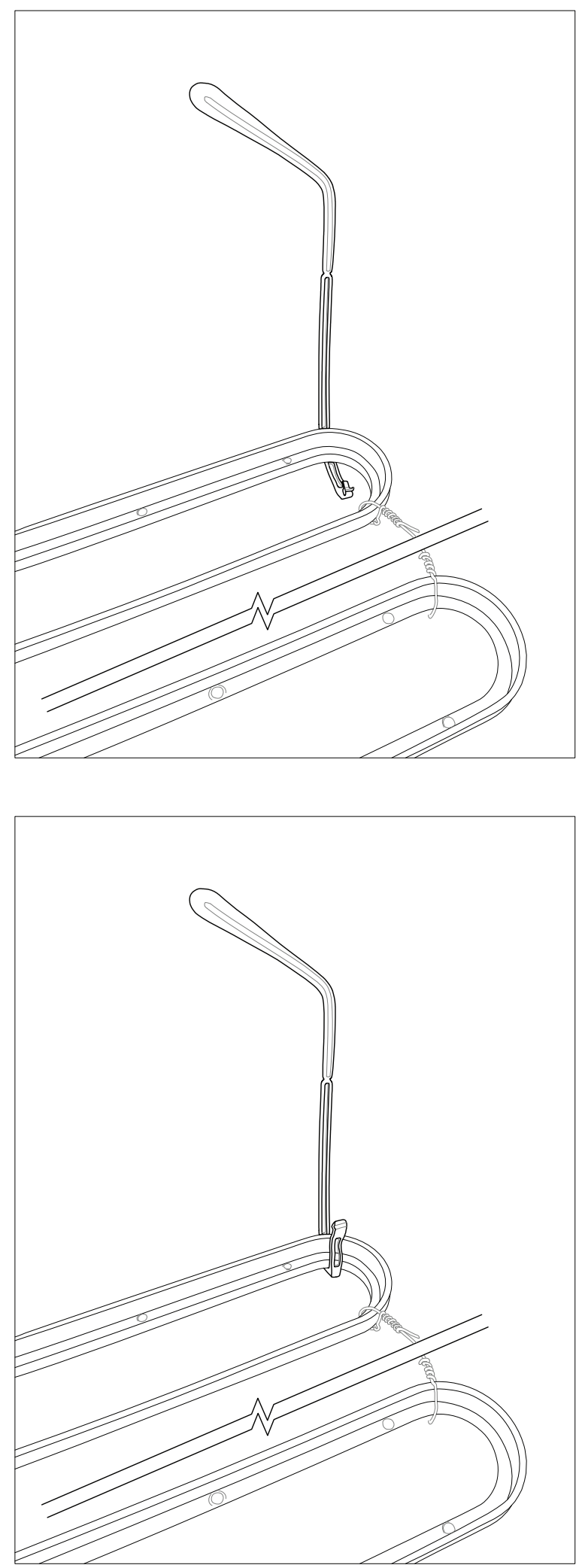

Illustration 42 Detail of securing sunglasses arm to speaker frames for support. 

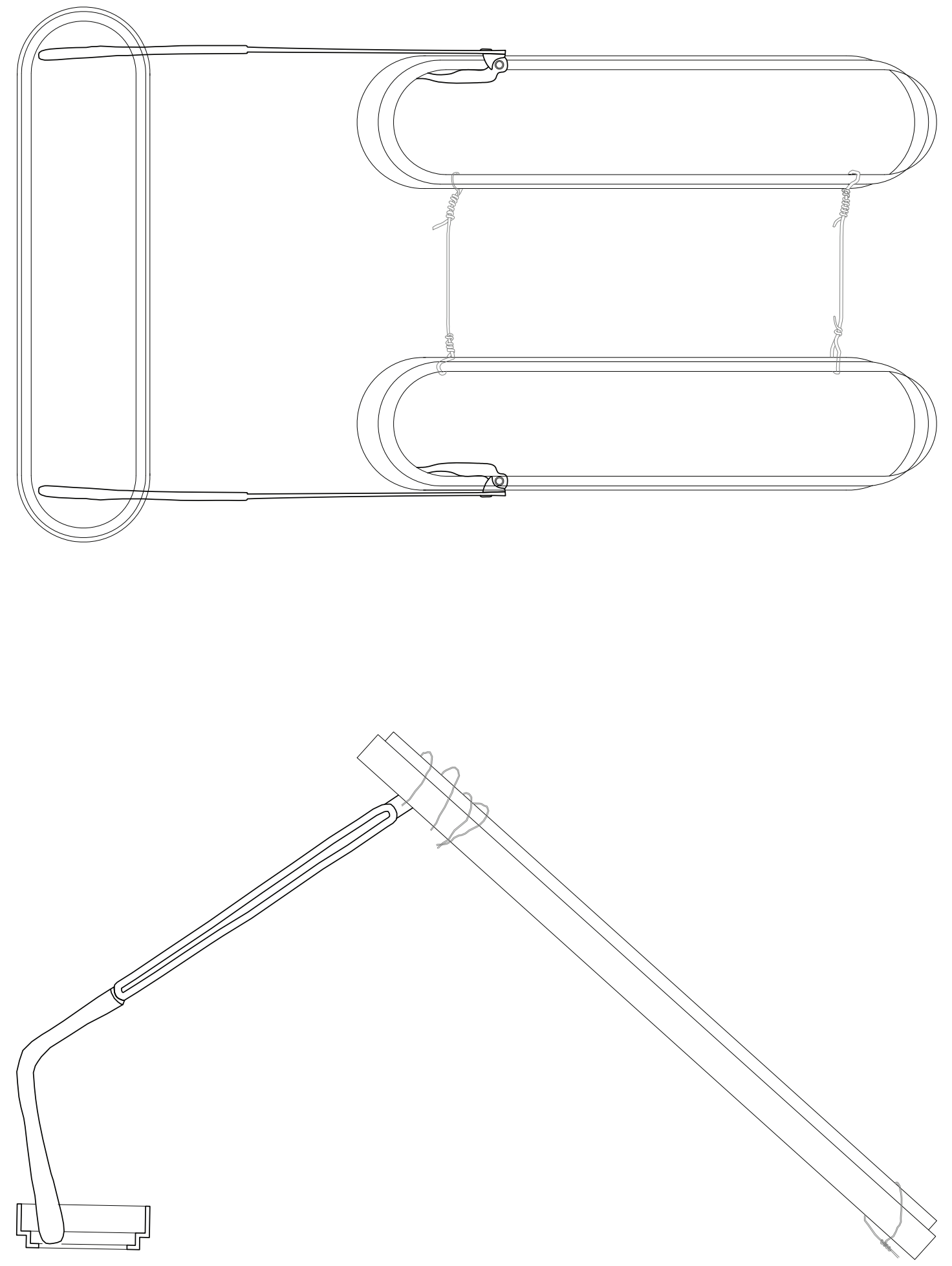

Illustration 43 Plan and elevation of standing form part 1. 

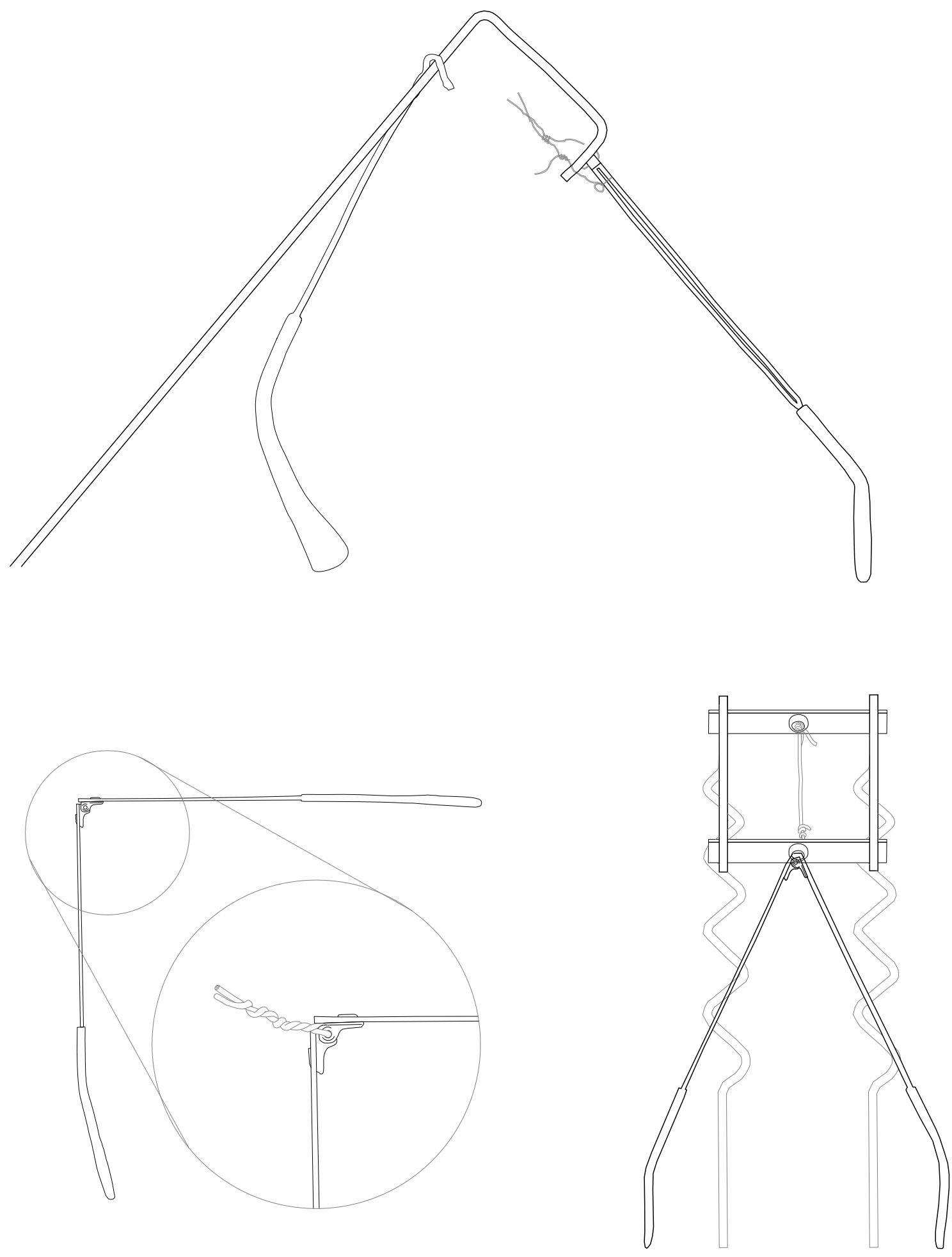

Illustration 44 Detail of attaching sunglasses arms to create part 2 of the form. 


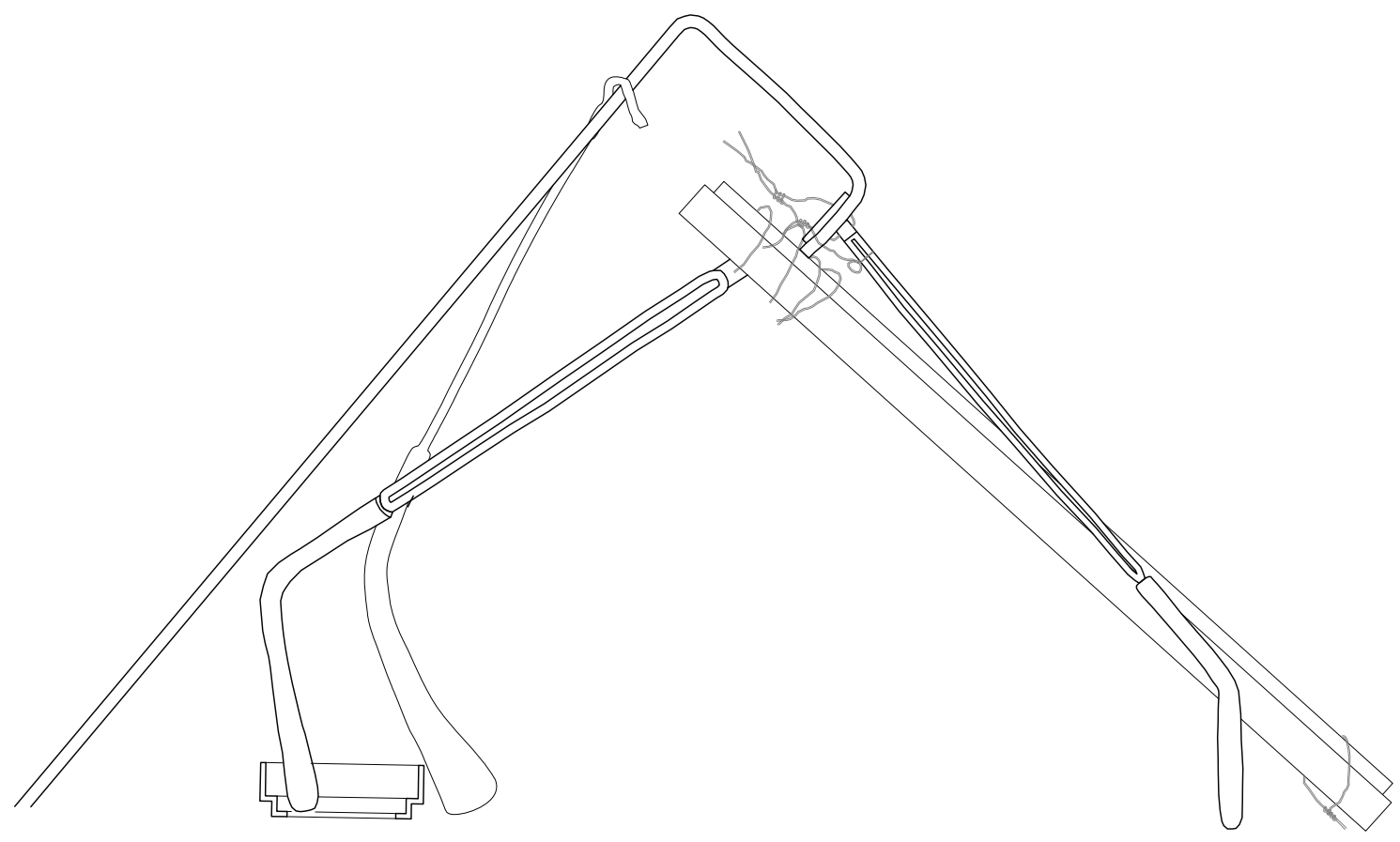

Illustration $45 \quad$ Final form combining part 1 and 2. 


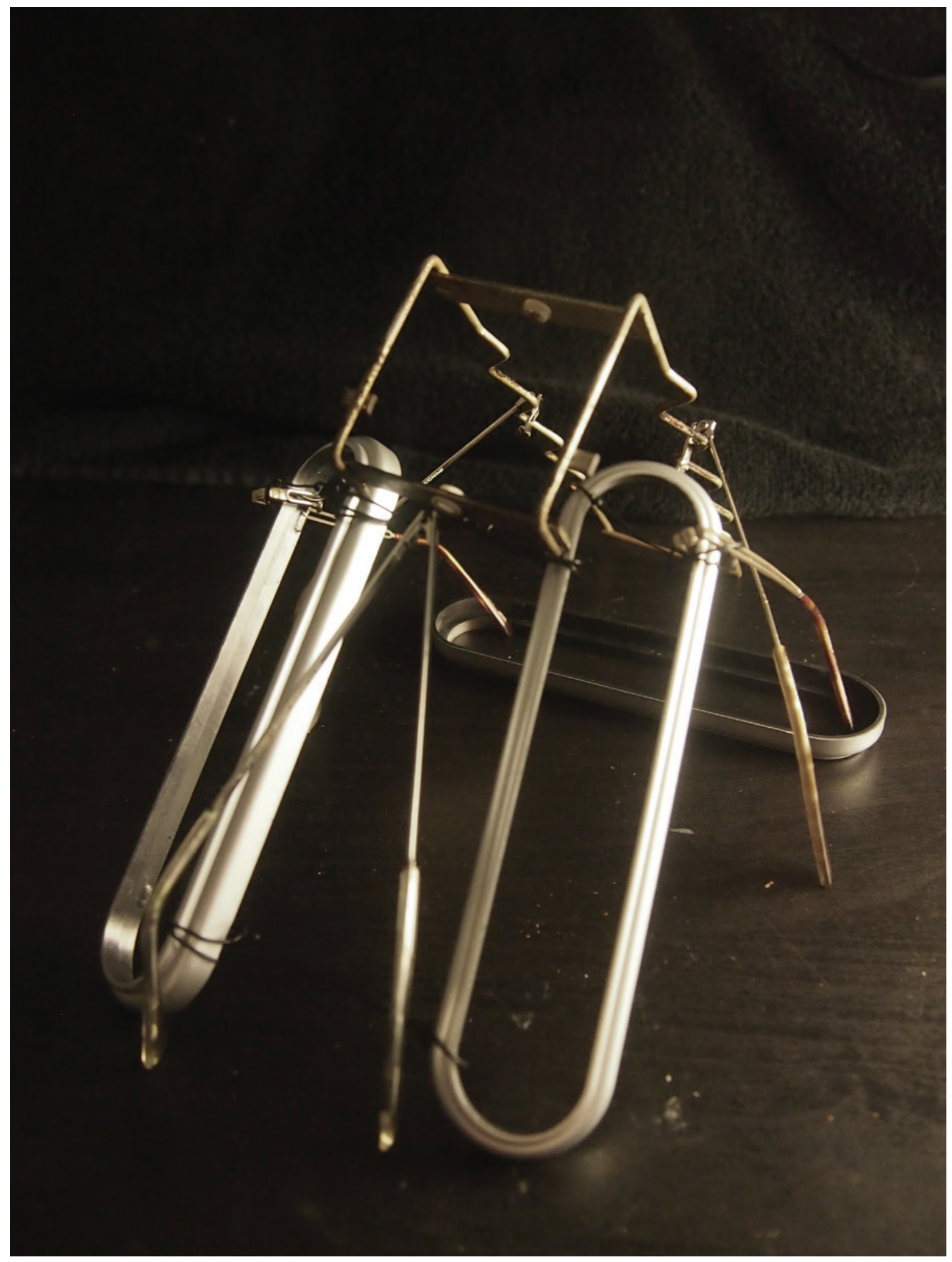

Illustration 46 Final form: "Parasitic Sunglasses." 

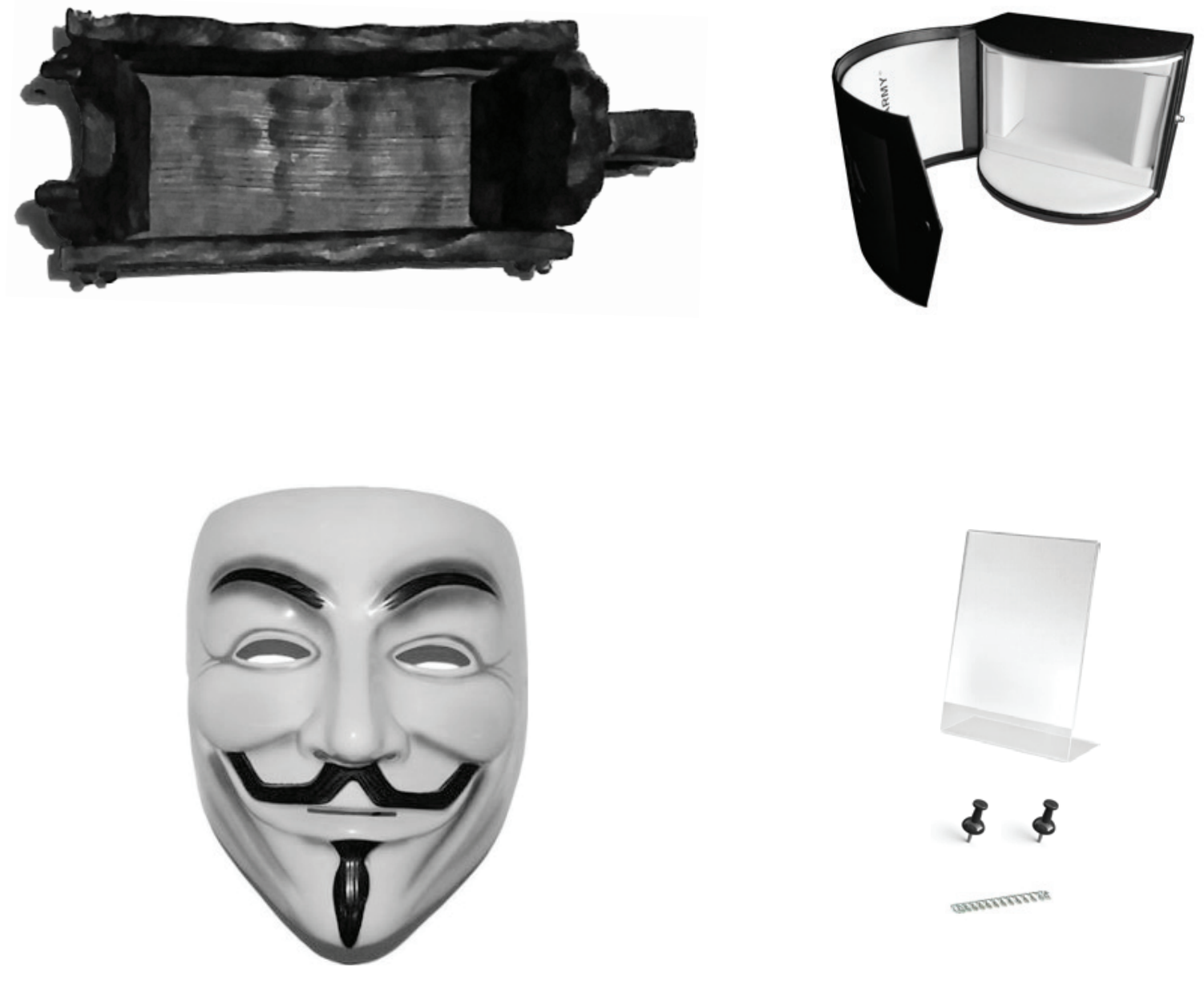

.

Illustration 47 Objects used in study. 

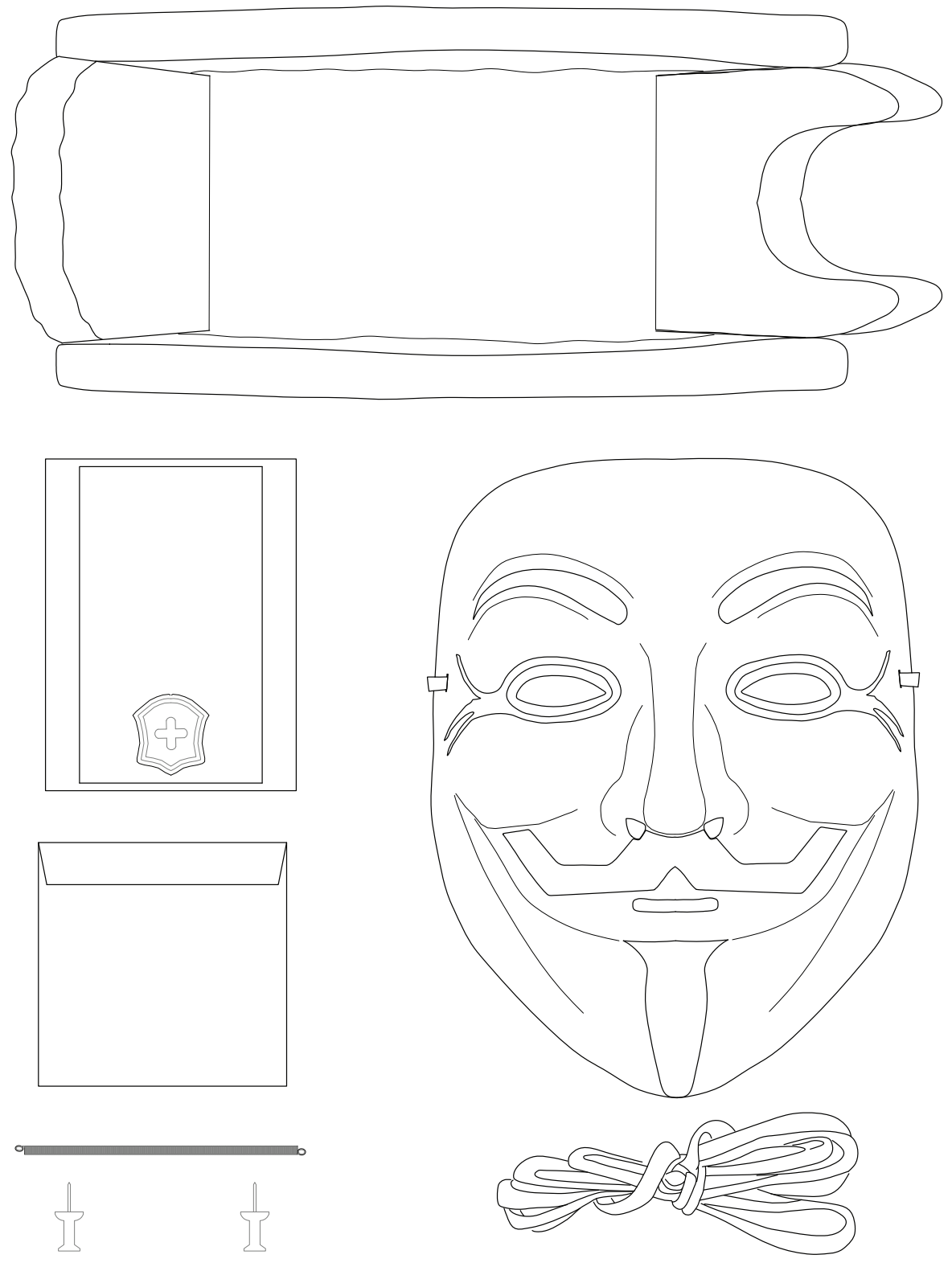

Illustration 48 Plan view of objects used including a mask, a shoestring, plastic photo holder, swiss watch box, spring, push pins, and a wooden cradle. 

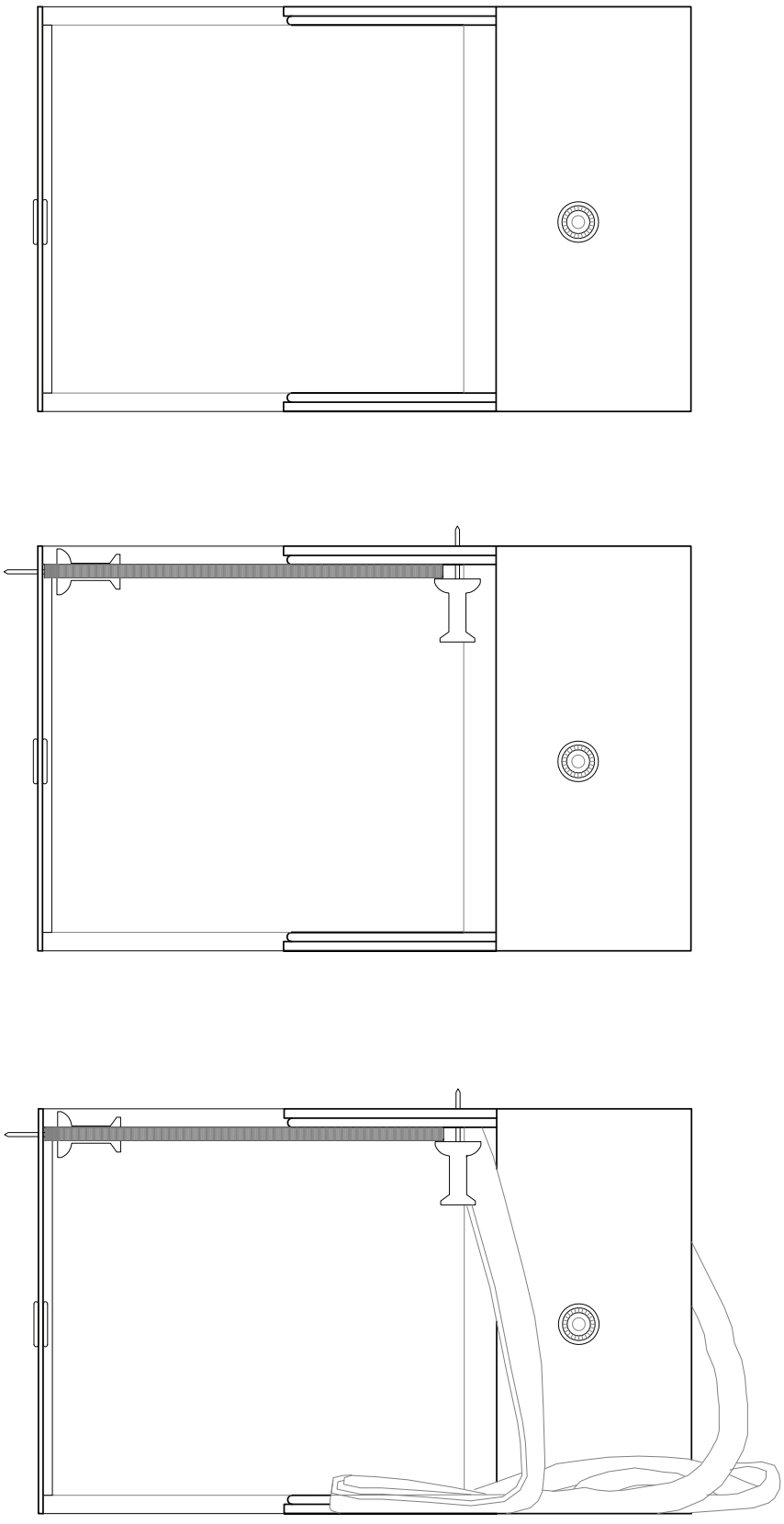

Illustration 49 Manipulation of watch box to open/close, and fastening of shoe string. 

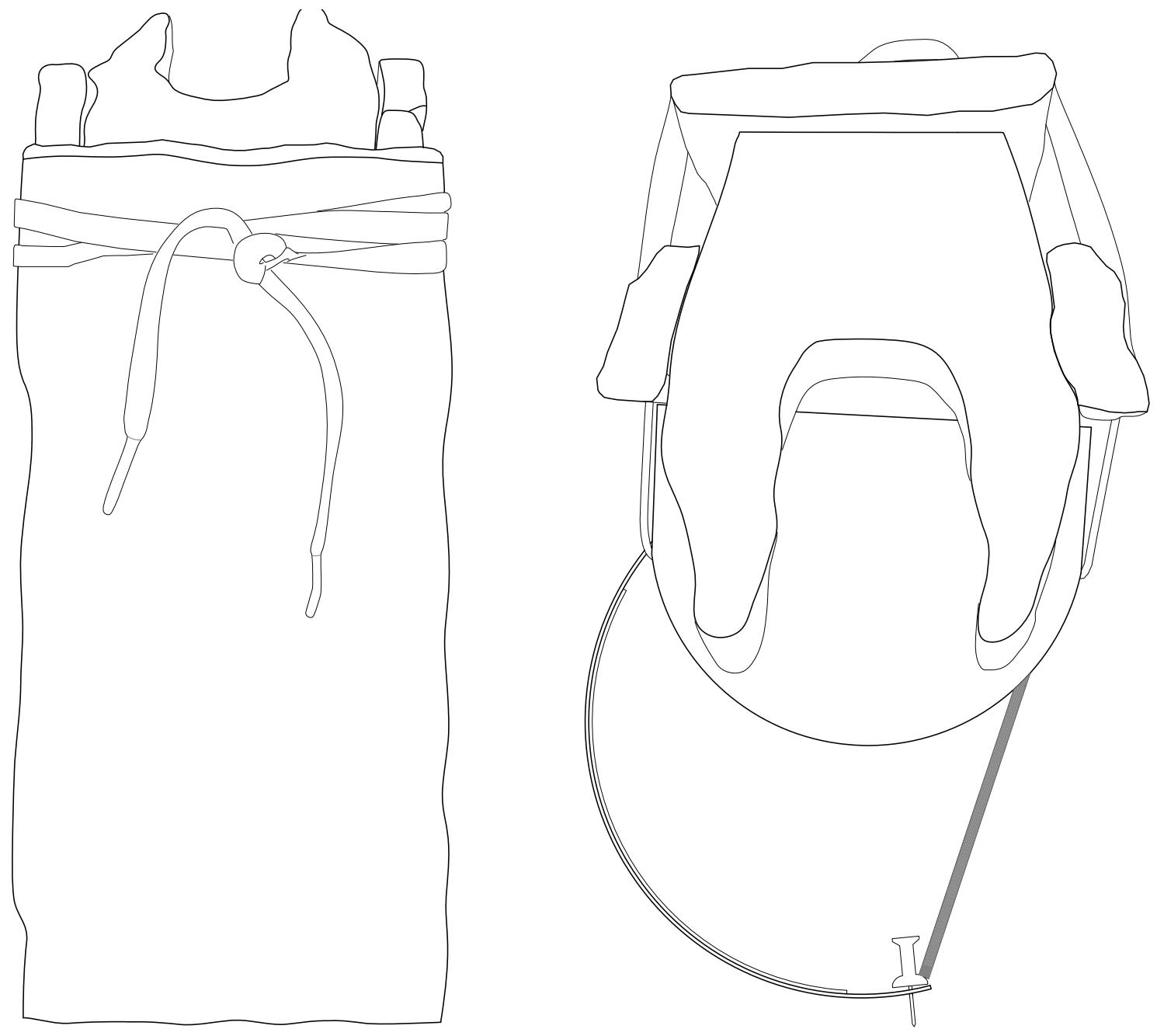

Illustration 50 Tieing of watch box and parts to wooden cradle. 

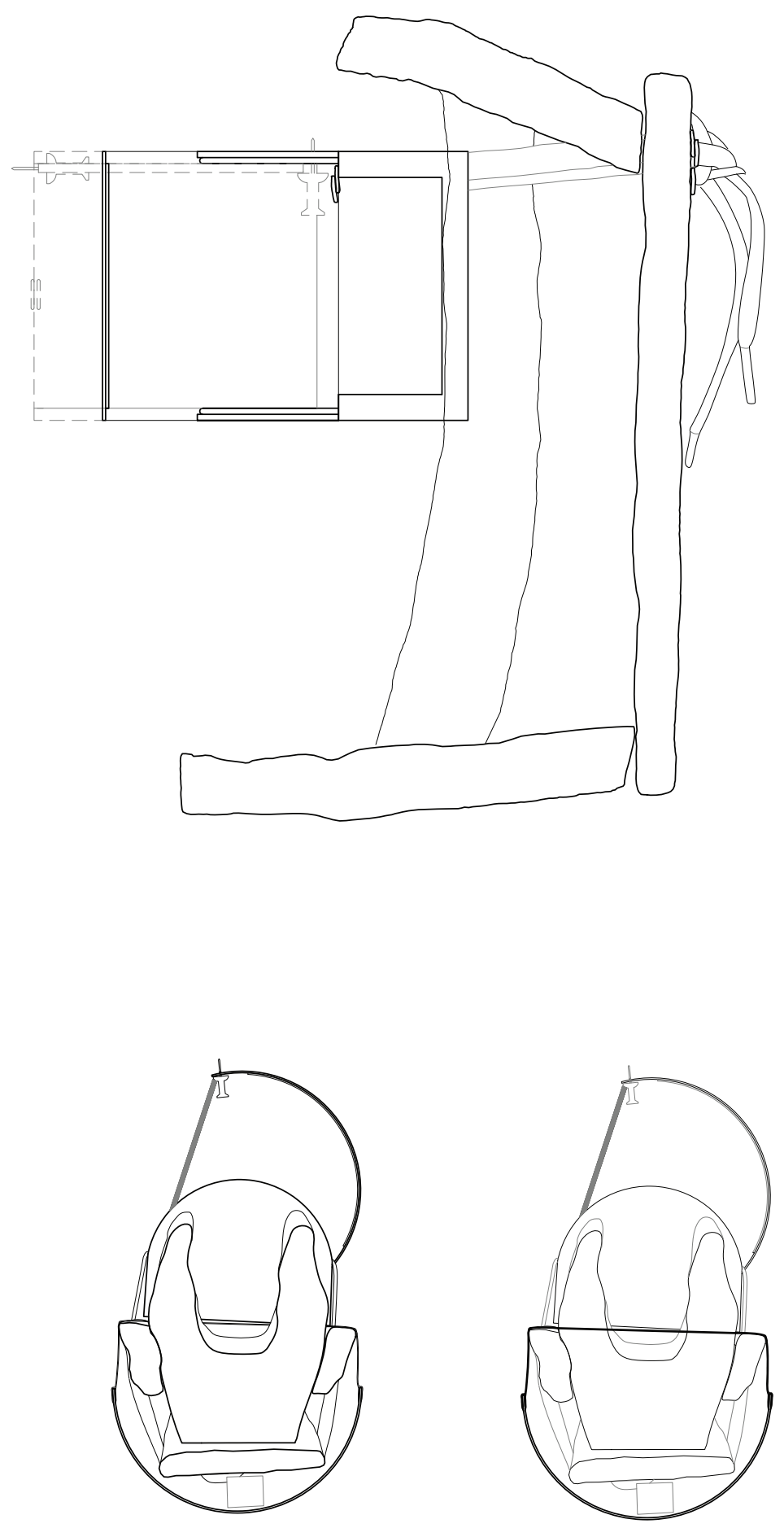

Illustration 51 Section showing attached watch box, and two plans showing the fastening of the mask. 


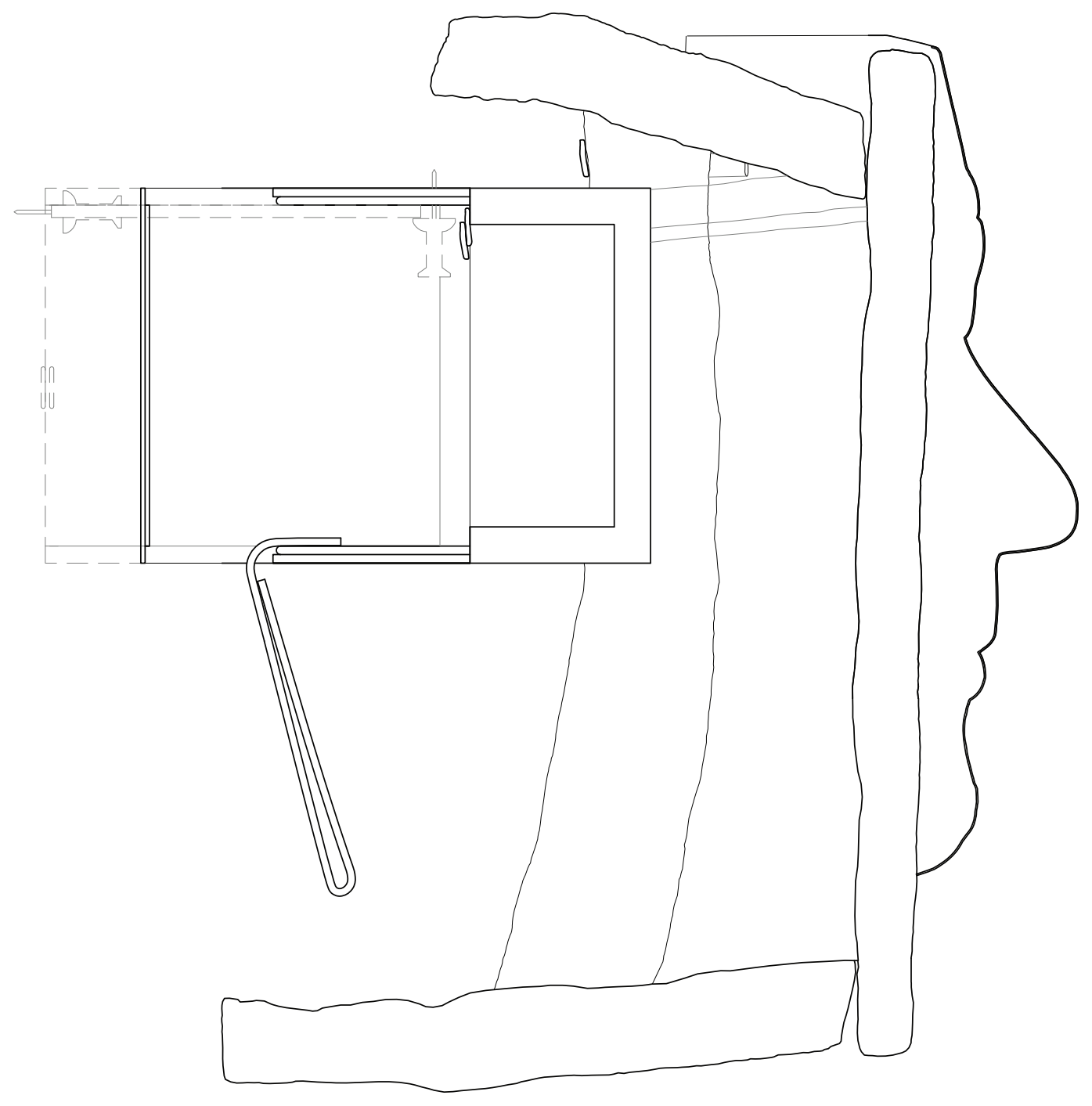

Illustration 52 Final form section. 


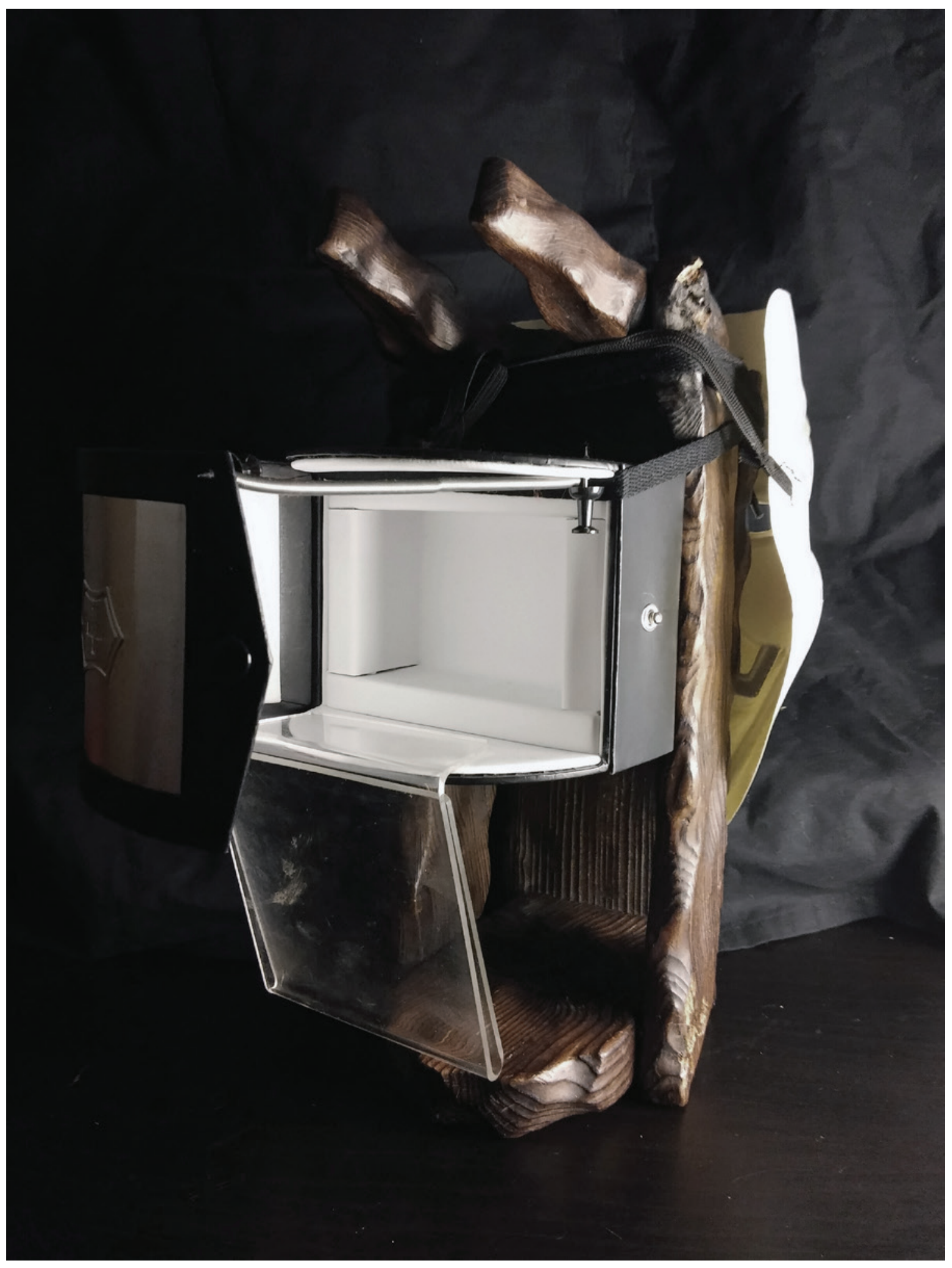

Illustration 53 Final form: "The Mask." 


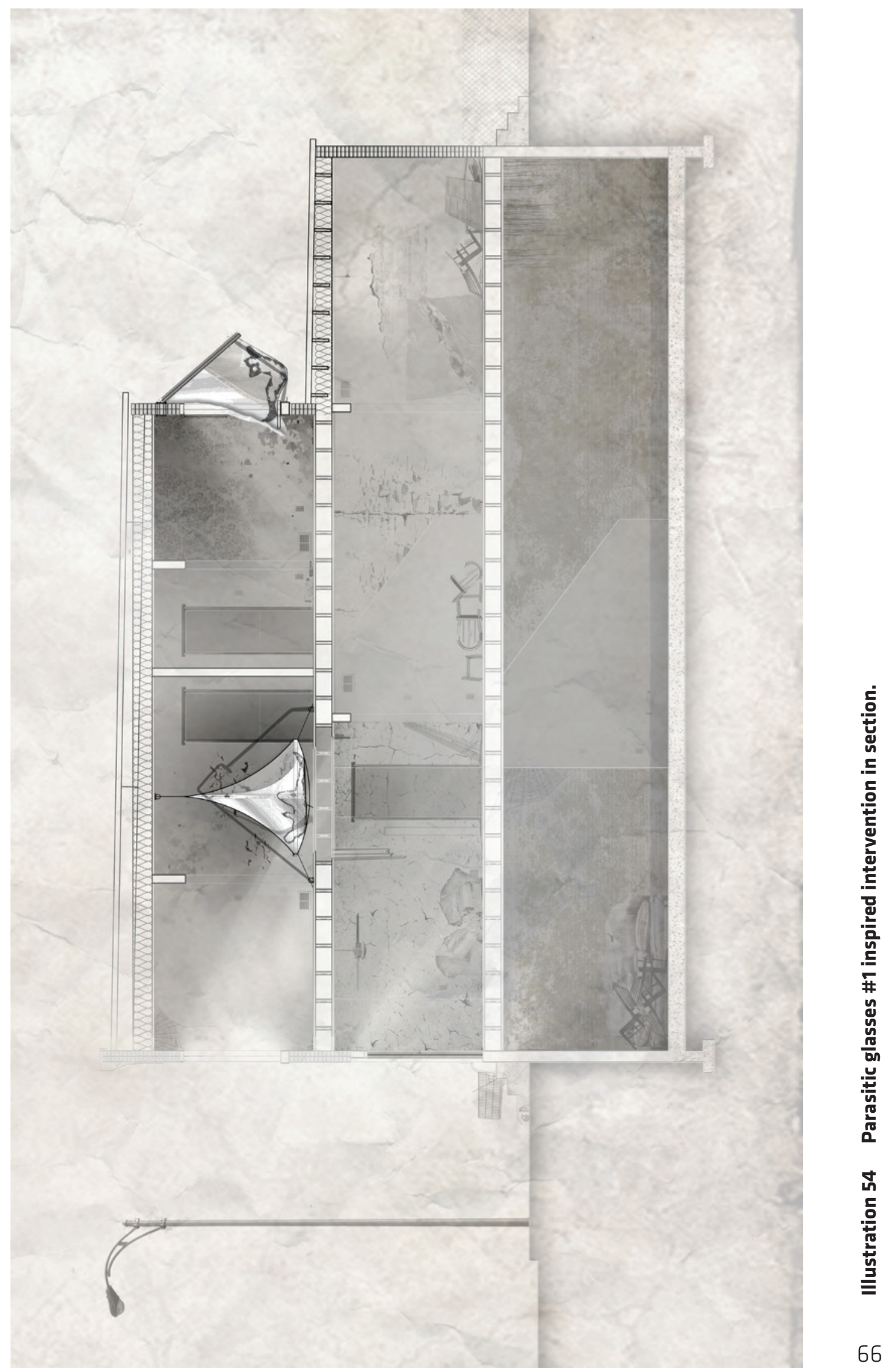




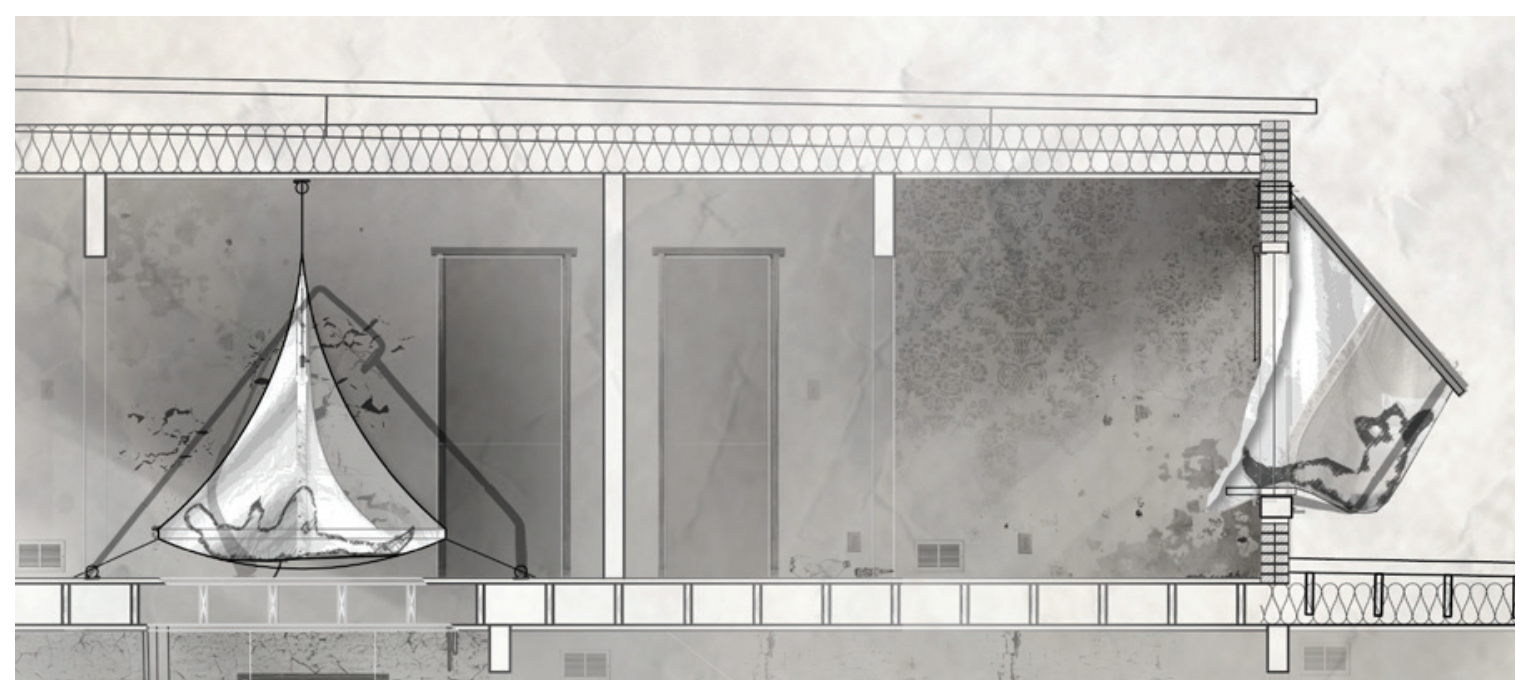

\section{Illustration 55 Close-up of the parasitic glasses inspired intervention.}

Following the Tiny Tradition where originally the homes were self-constructed, these structures would use the structure as a sort of backbone. For buildings that are in a state of disrepair, this allows individuals to construct their homes surrounding, on top of, as a part of, or hanging from the existing structural elements. For neighborhoods that have a large number of abandoned homes or dilapidated buildings, this allows individuals to insert their home's functions into the existing fabric and use the building's structure which might otherwise be unusable or uninhabitable.

The reclamation of abandoned homes by the homeless is a stand against

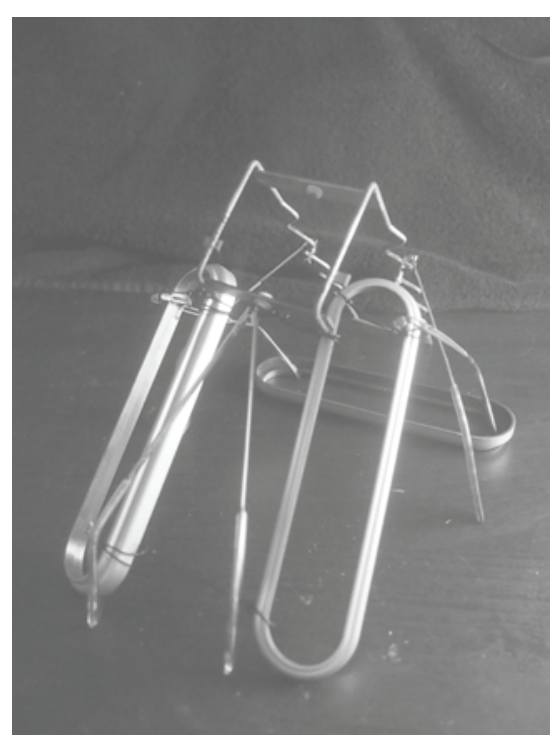

the manner in which cities are continuing to view

the homeless. The representation above is a

demonstration of the extent that the homeless must

go to in order to find shelter. Instead of pushing away those that are the victims of misfortune, how can the outcast be brought back into society?

Illustration 56 Study used as inspiration. 


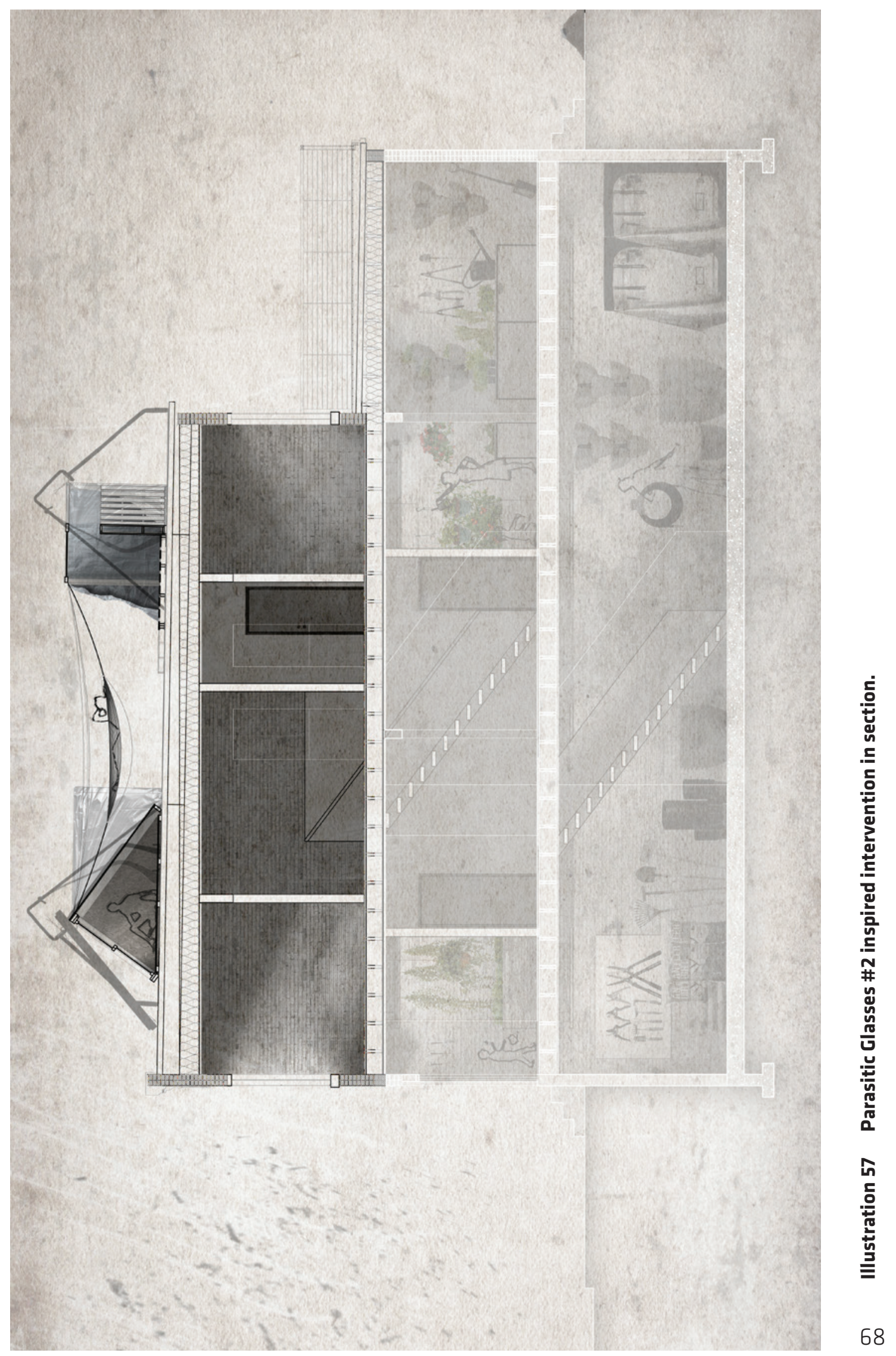




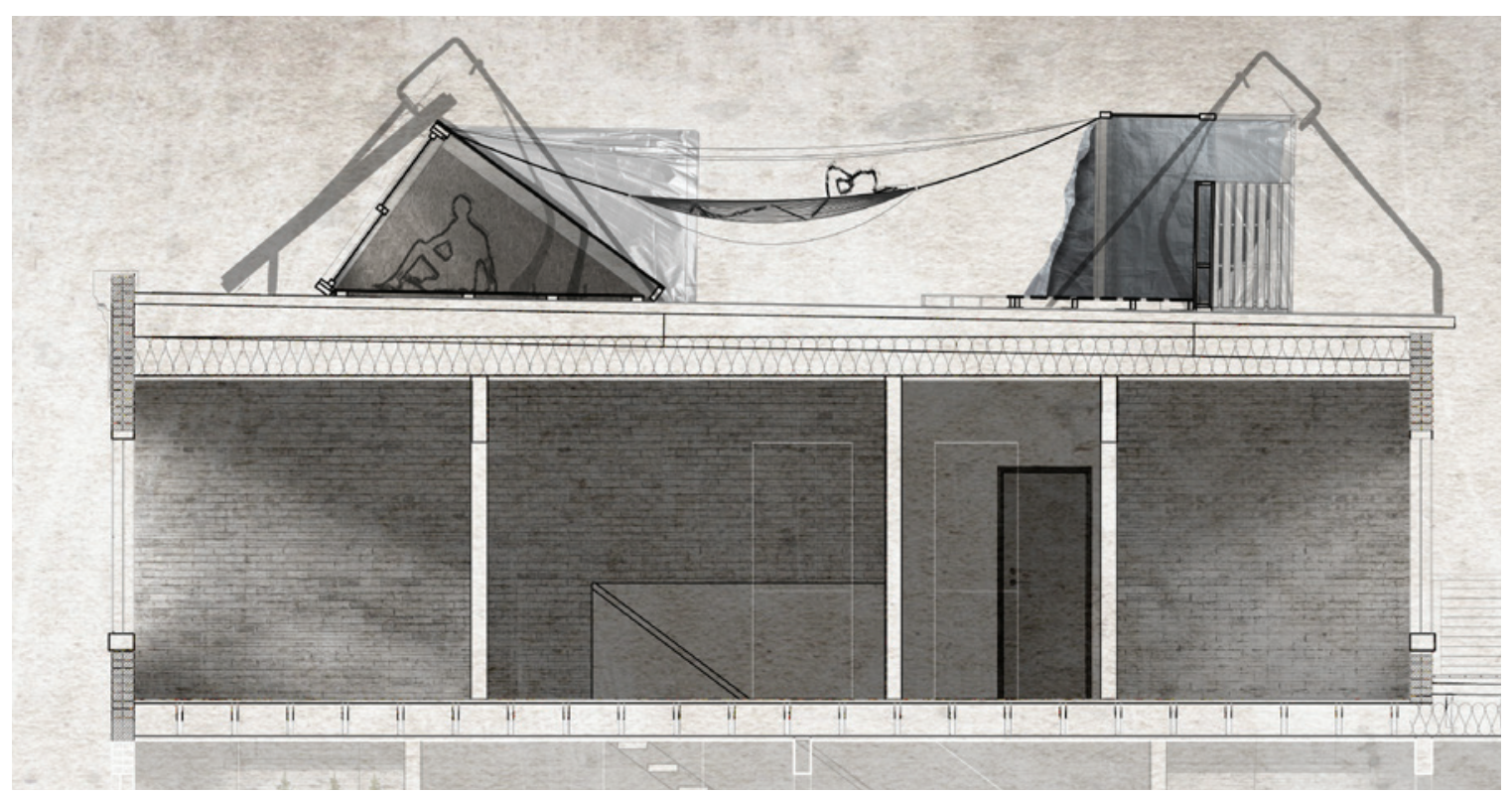

\section{Illustration 58 Close-up of the parasitic glasses \#2 inspired intervention.}

Inhabiting and reorganizing existing structures can turn the regular house into a tiny house. Reducing the living spaces to one floor, and converting the remainder to public functions changes the private home into an extension of the community. Many historical homes used the first floor as mercantile space, but they were rarely community spaces. In this example, the front yard is brought inside, turning the first floor into a community greenhouse/garden.

The use of the parasitic glasses study in a second section is intentional as it

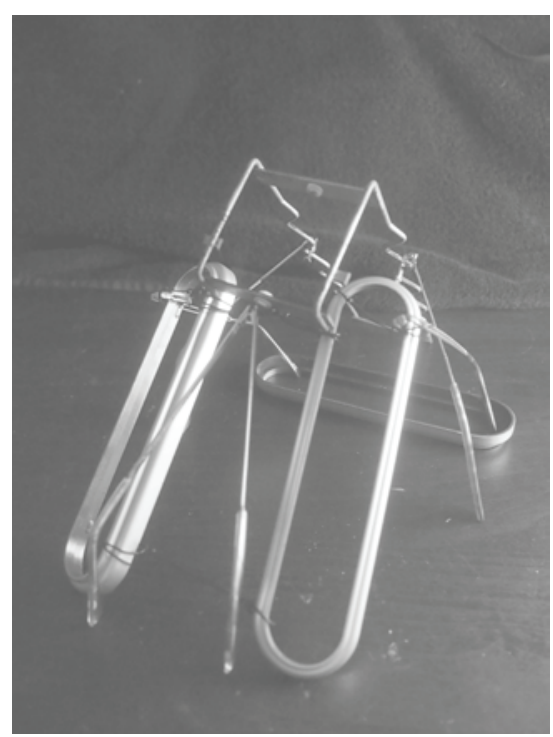
shows how placing the same idea in a different context allows for a different interaction amongst occupants. When placed on the roof of a home under renovation, the intervention no longer becomes parasitic, but rather symbiotic. The presence of the farm is essential as it provides food, but also serves as employment. Urban farming is an option for work that allows the homeless to sustain themselves, but also makes them contributing members of society.

Illustration 59 Study used as inspiration. 


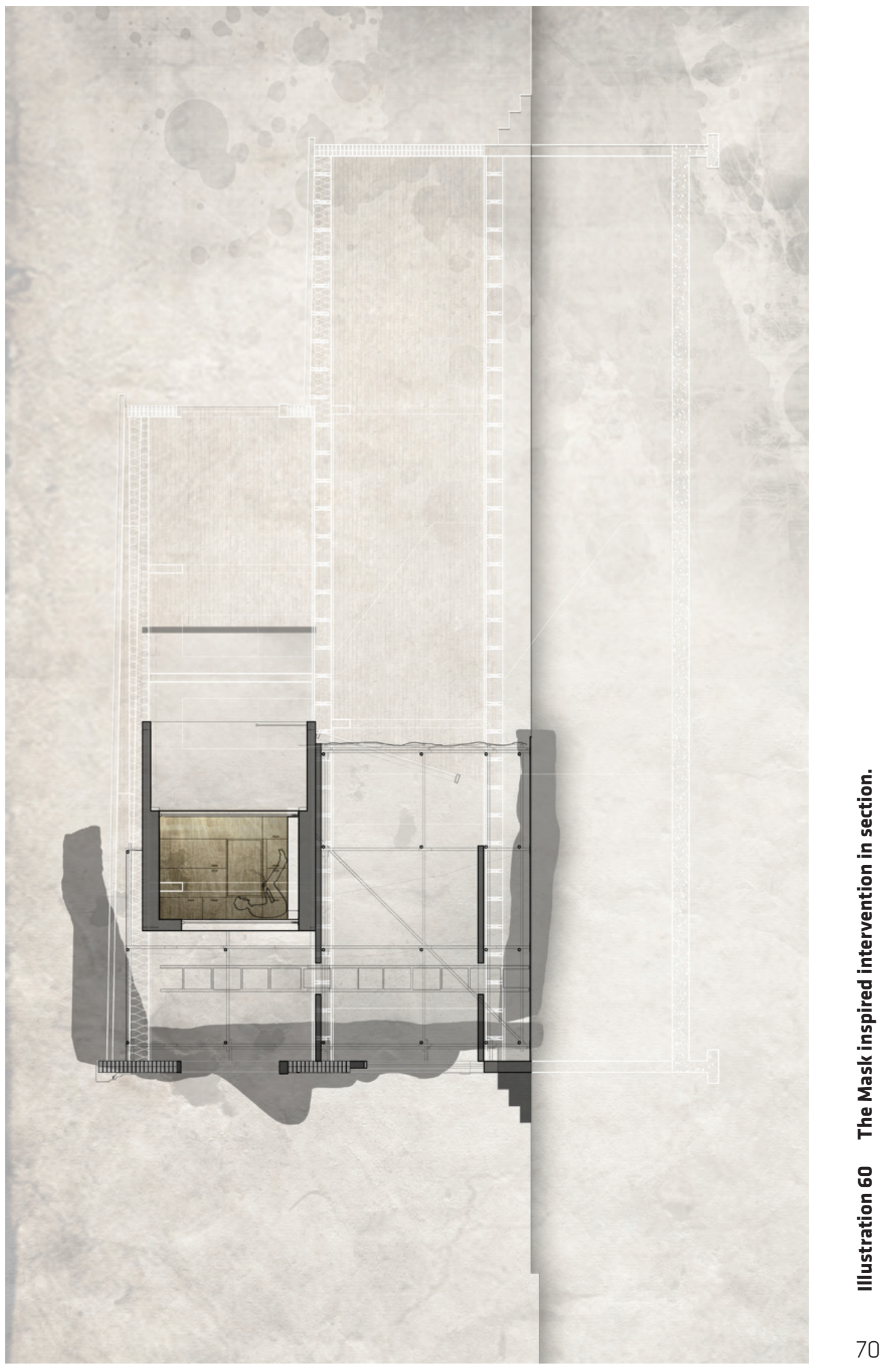




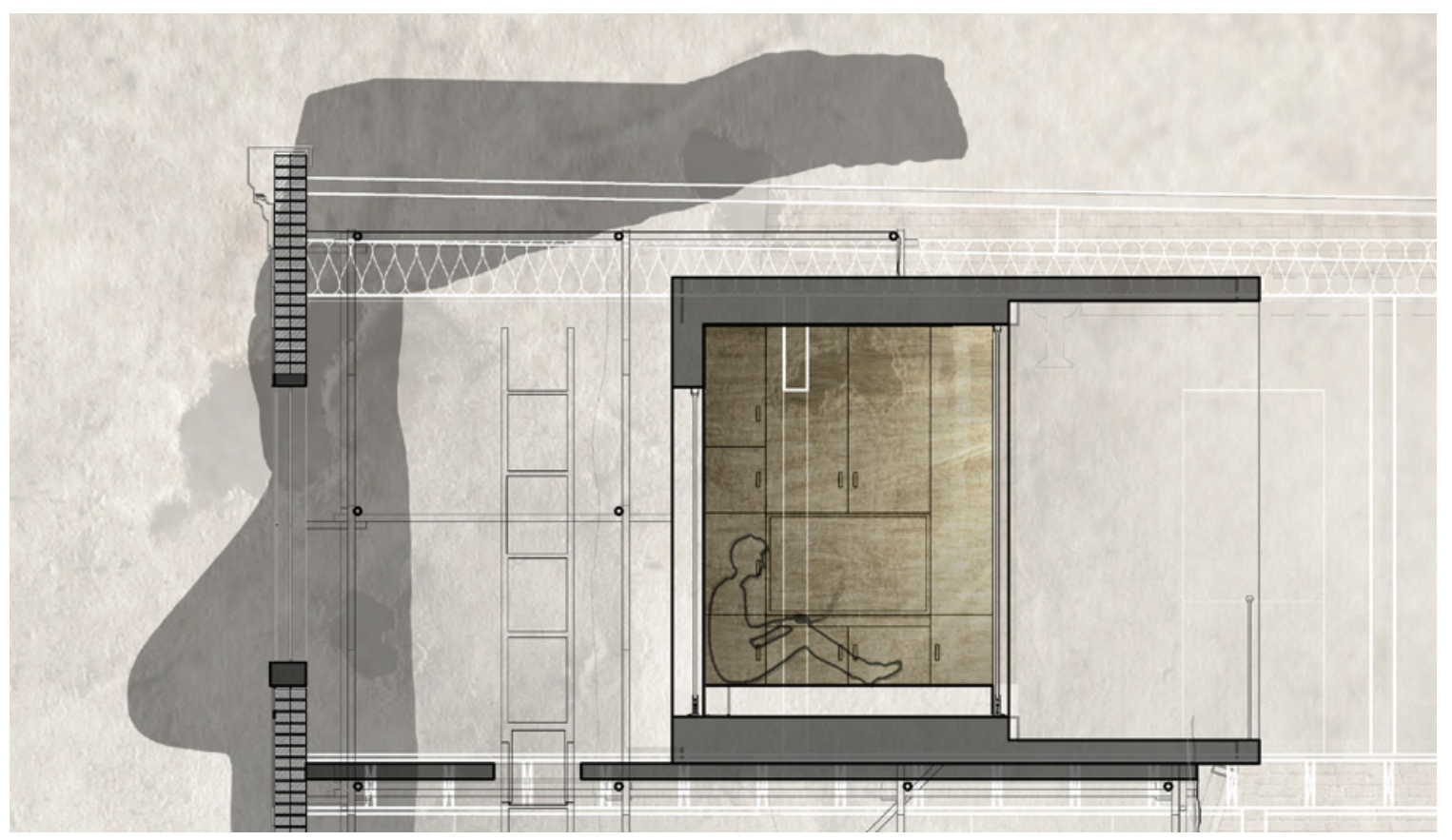

\section{Illustration 61 Close-up of The Mask inspired intervention.}

The architectural identity of Baltimore is the rowhouse. The marble stoop, narrow front walks, and the repetitious facades bring out the slight variances of their common form. If there is any part of the home to maintain, it is the main element contributing to the urban fabric. How then can this be preserved?

The Mask study offers an interesting insight. Representative of hiding what is underneath, the mask draws parallels to formstone, a popular product in the 50s, when

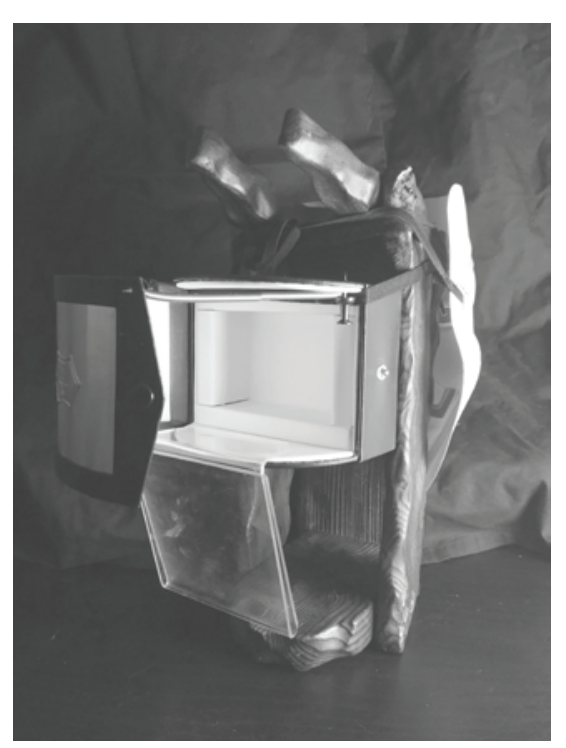
put in this context. As brick was viewed as a cheap building material, stone veneer (formstone) was used to add aesthetic sophistication. As the mask hides the structure, and the formstone disguises the brick behind, so does this intervention shelter itself behind the front facade. Predominantly structural, the home allows flexibility through the expansion and construction around the structural scaffolding. 


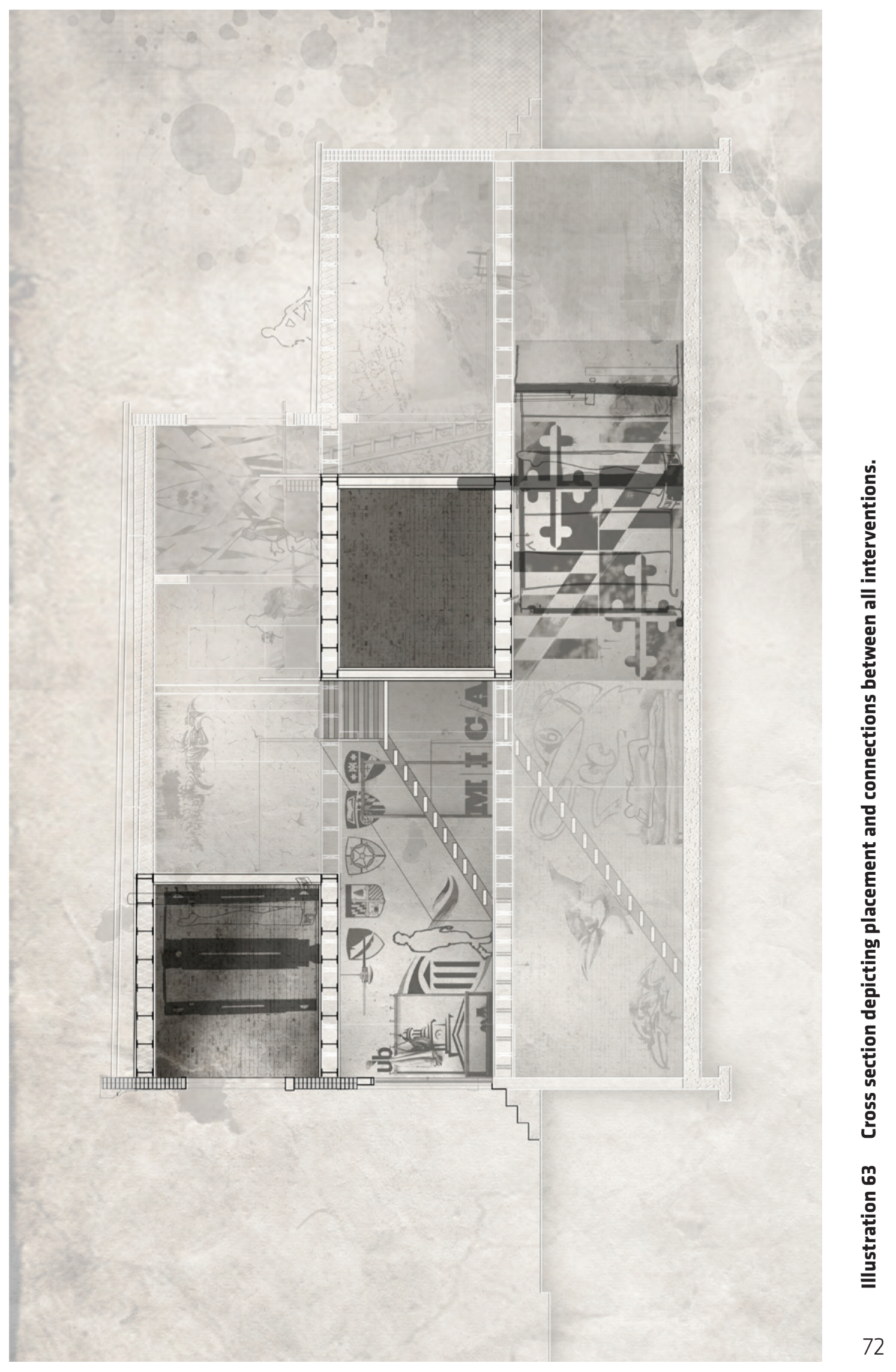




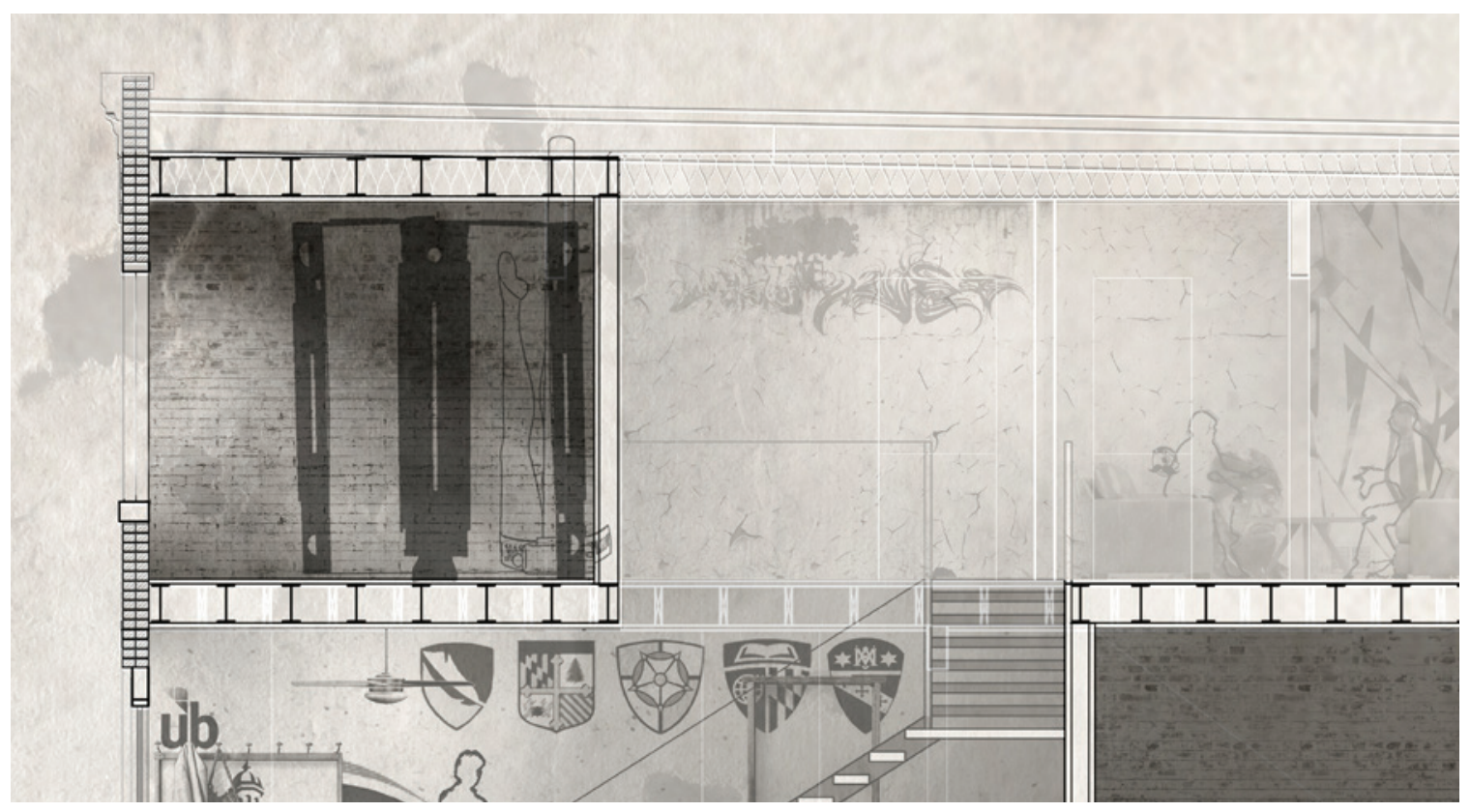

\section{Illustration 64 Close-up of the parasitic glasses \#2 inspired intervention.}

For the structures that are severely dilapidated, but deemed worthy of saving, a Tiny House can be inserted to help save the house. Transforming the single family house into a series of individual dwellings, the original structure now becomes the support for a small community which has the ability to expand to neighboring buildings and structures. Inserting these constructions has the potential to reinforce the structure, while maintaining the front facade, or the main identifying element of the home. The rest of the home can continue to deteriorate all the while revealing a new home from the rear.

The introduction of art or architecture students from local universities to this

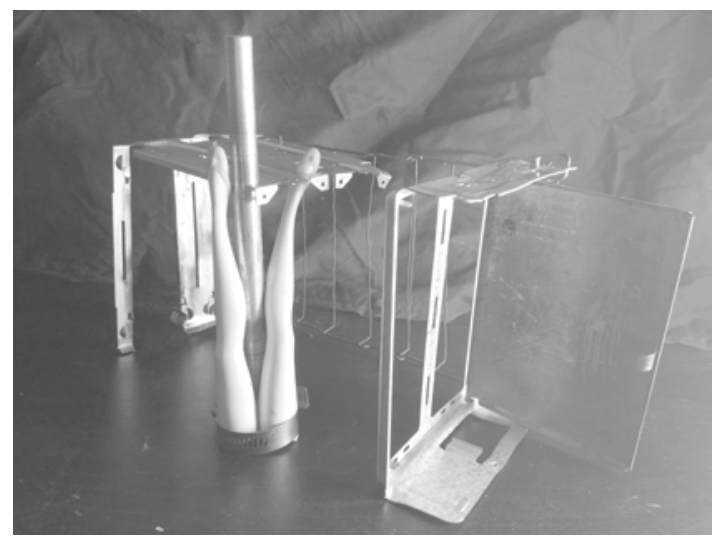
intervention can lead to great possibilities. If the inhabitants are given free reign over the remainder of the home, these spaces can become social spaces, impromptu galleries, designed nooks, or installations. 

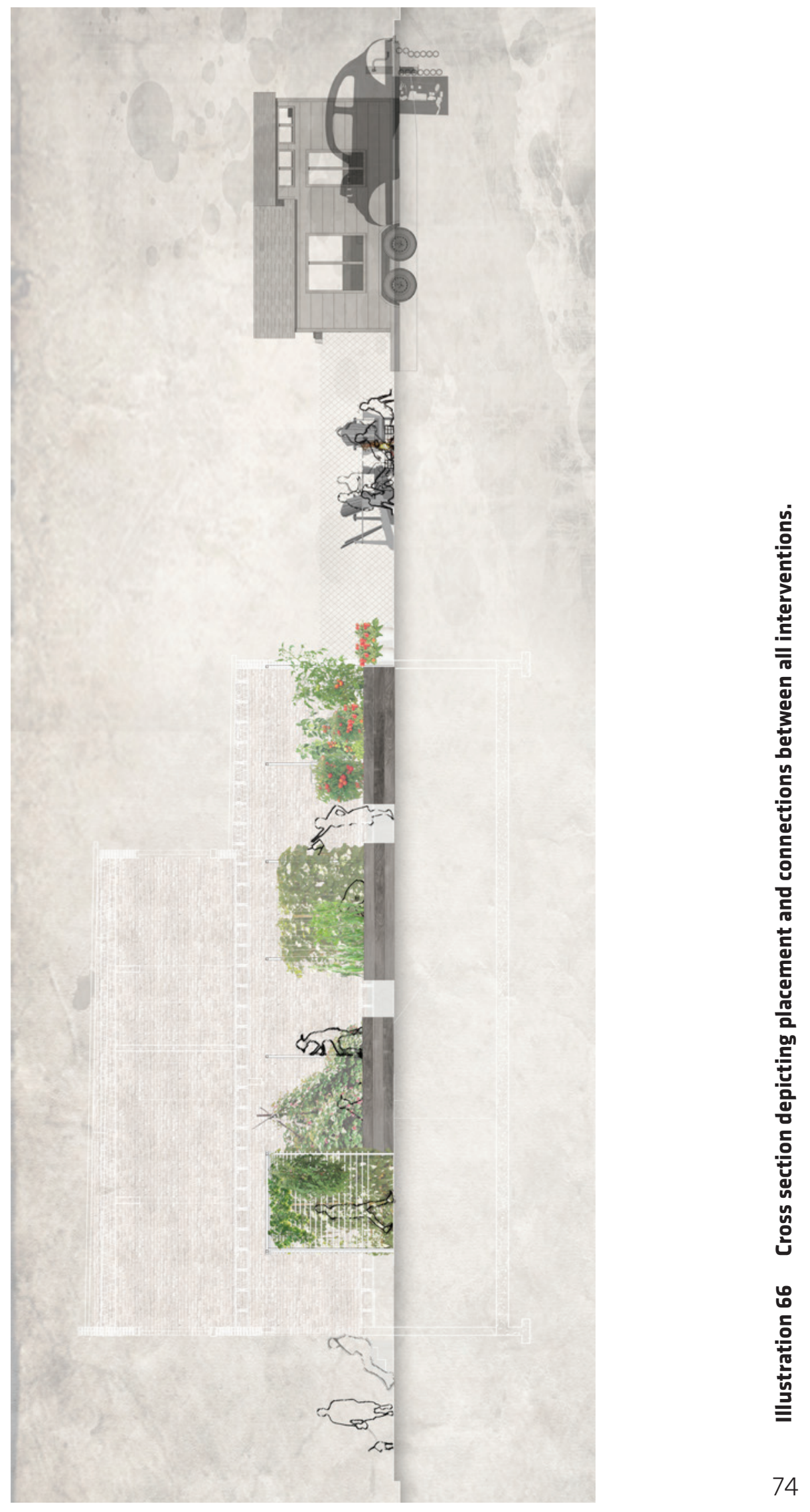

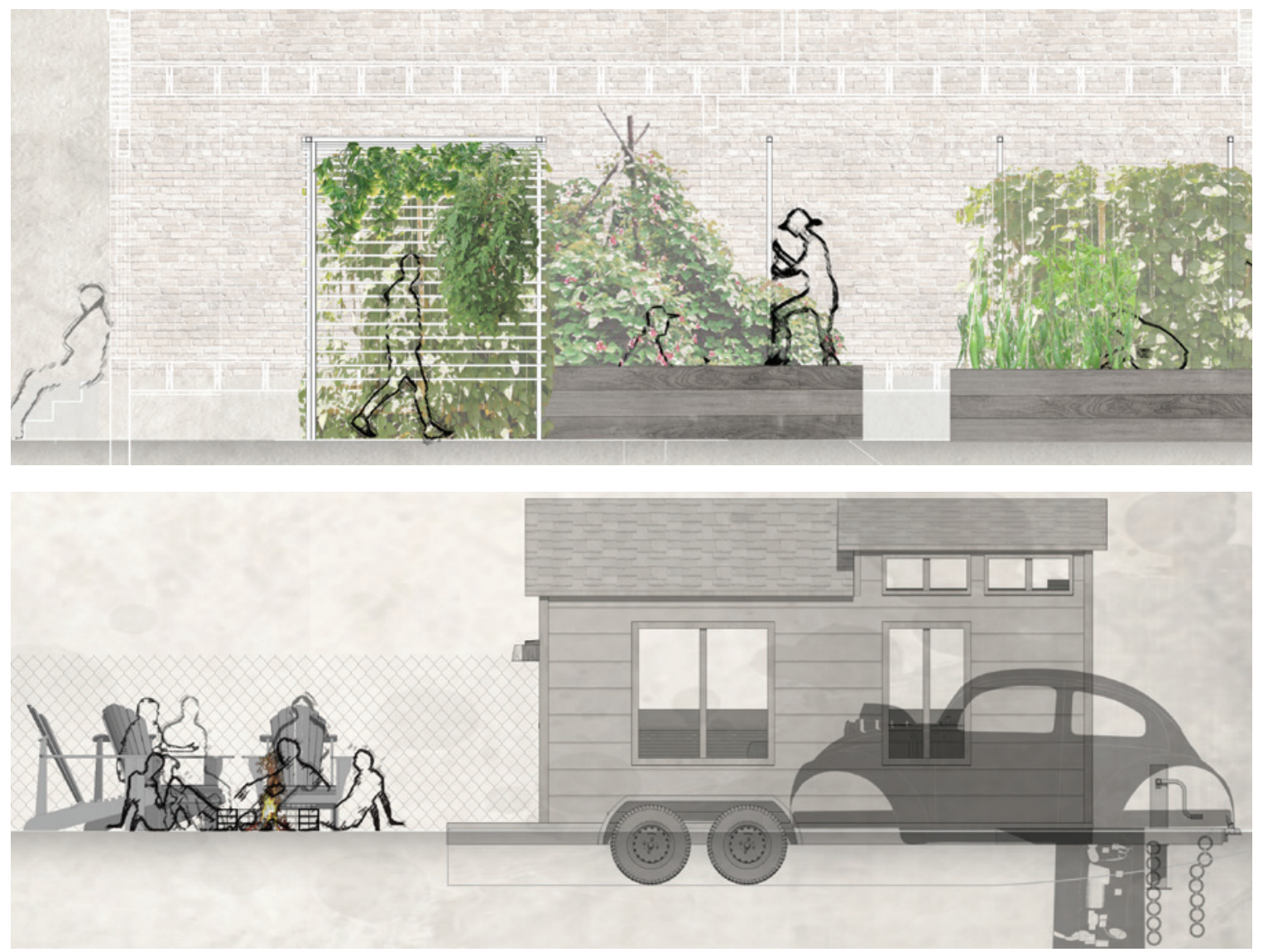

\section{Illustration 67 Close-up of the Car inspired intervention.}

Demolition of rowhomes leaves the urban fabric with missing holes, as it can take years, to develop these sites. If the demolition of abandoned homes leads to abandoned grassy lots, why not allow the community to assume responsibility, and convert the land to a neighborhood urban farm? Urban farms do not pose a threat to future developments, which only increases their viability as an option for unused lots. As

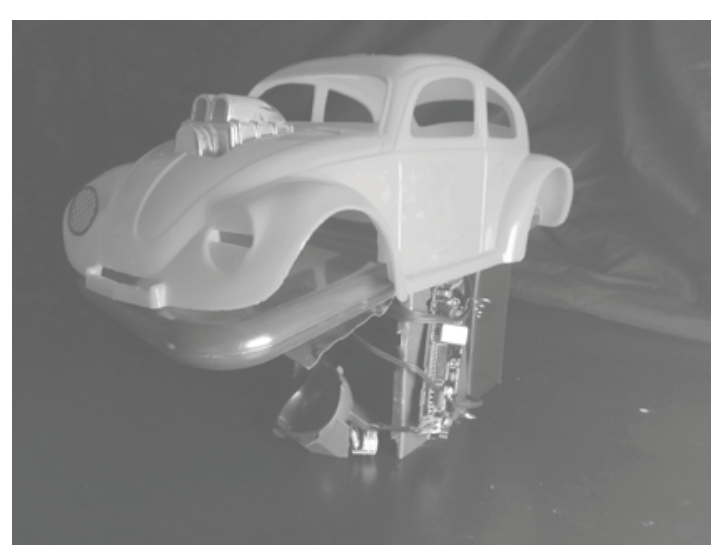
more lots are created through the removal of blight, more opportunities arise to assist the vary neighborhoods in need. Quite rapidly, the site, or a portion of the site, can be transformed into a space for a permanent or movable tiny home.

Illustration 68 Study used as inspiration. 


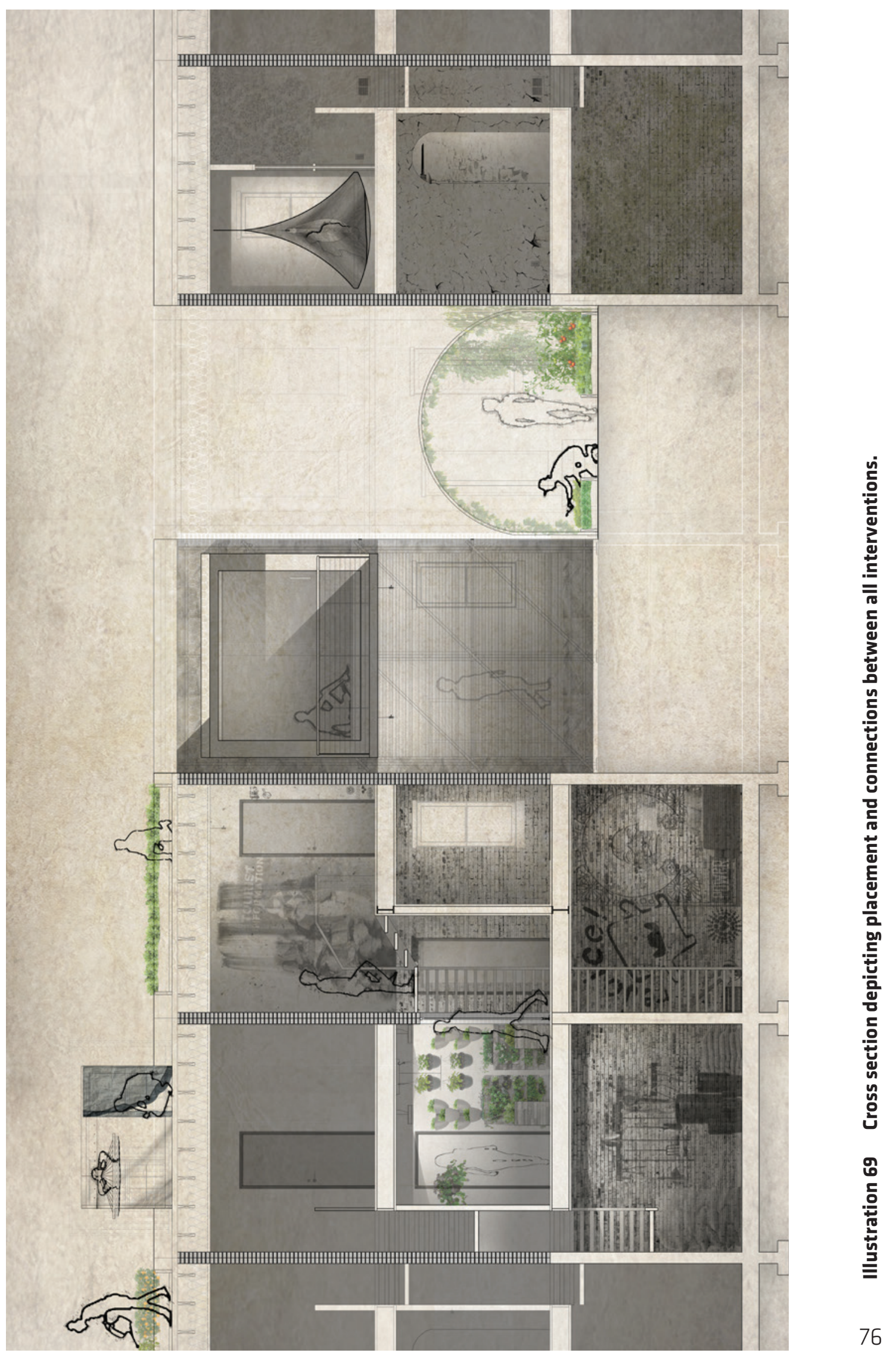




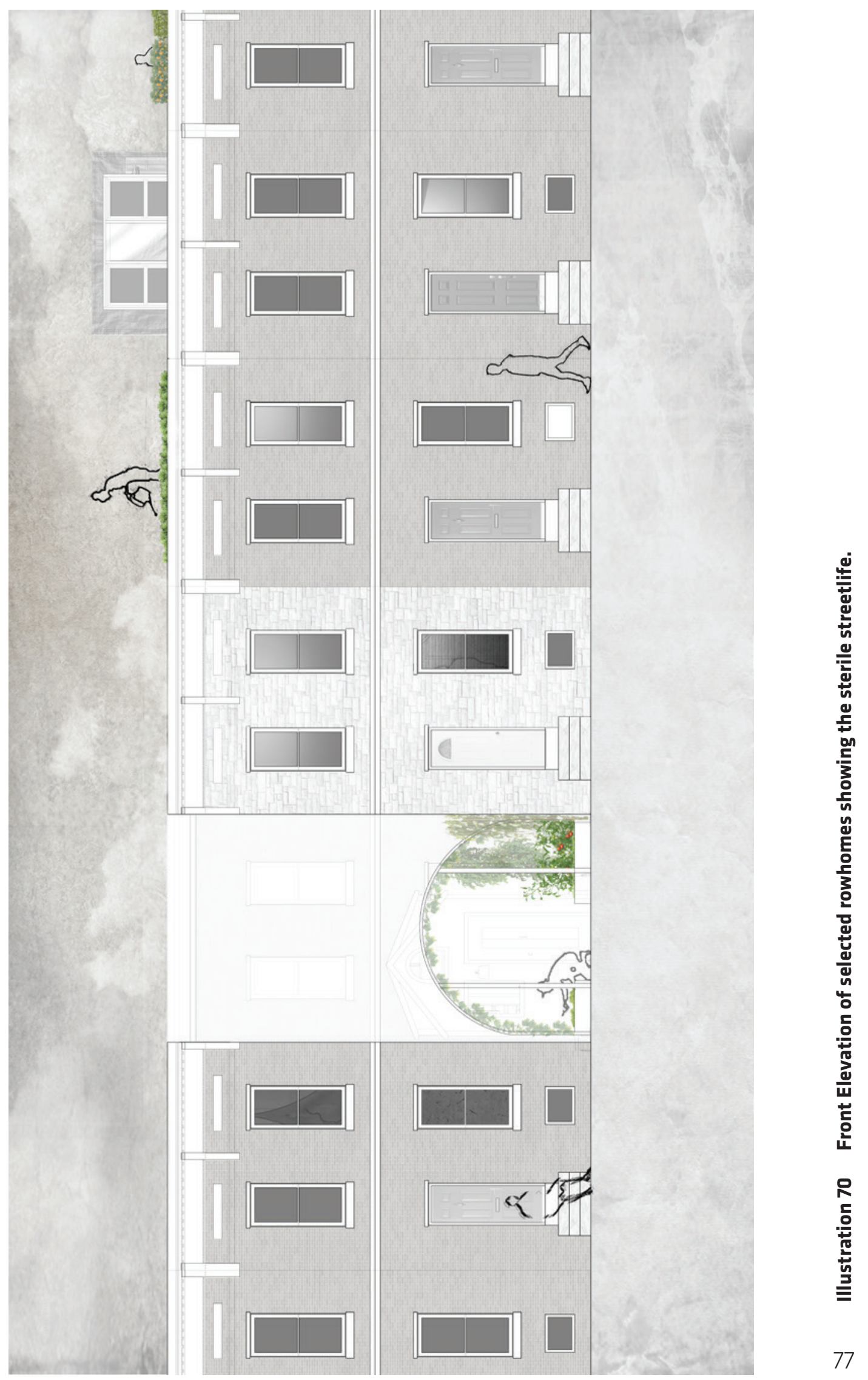




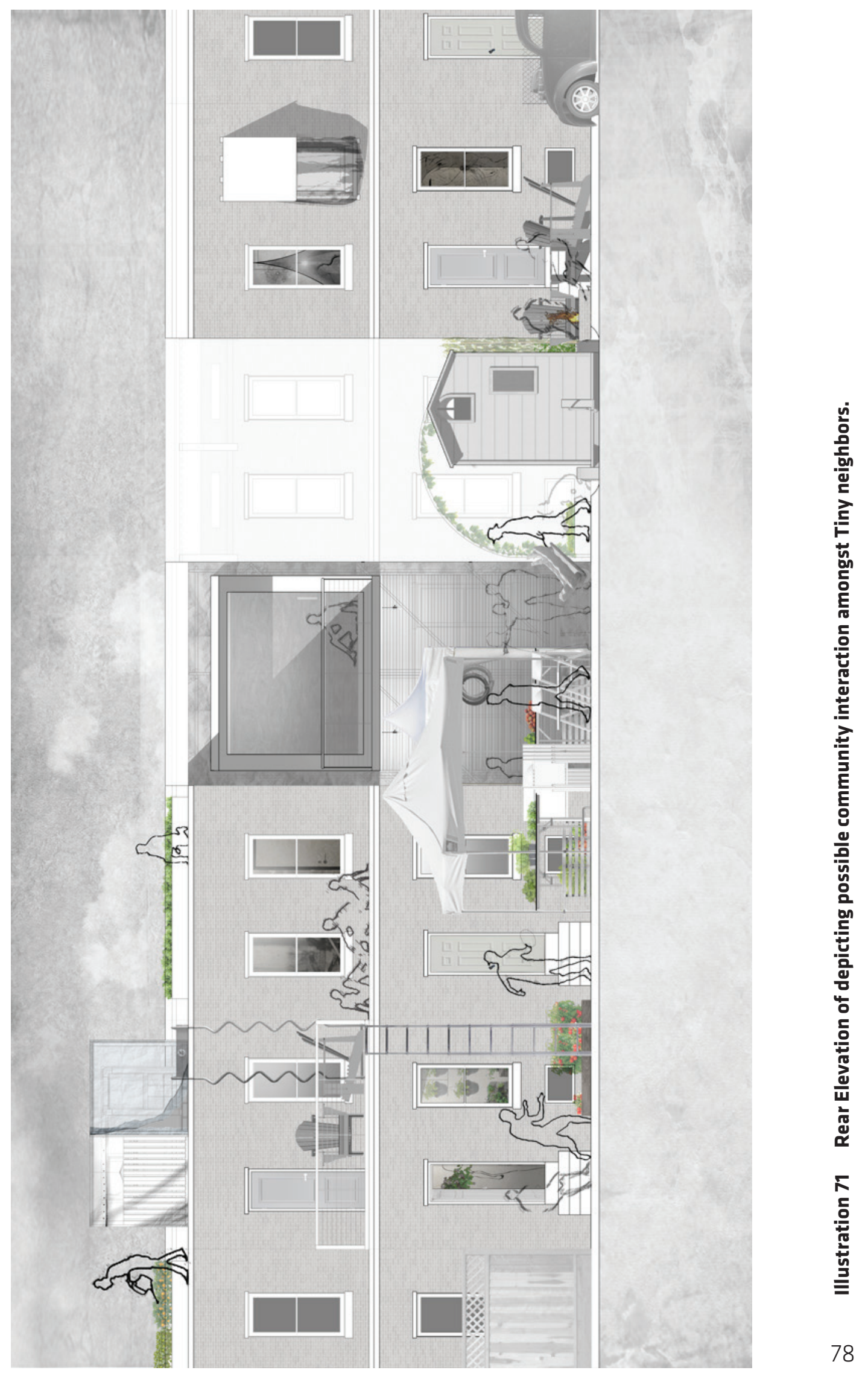




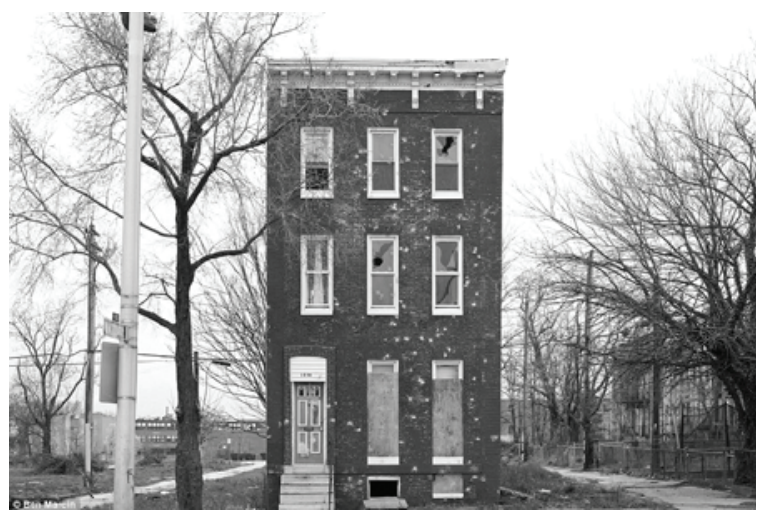

(a)

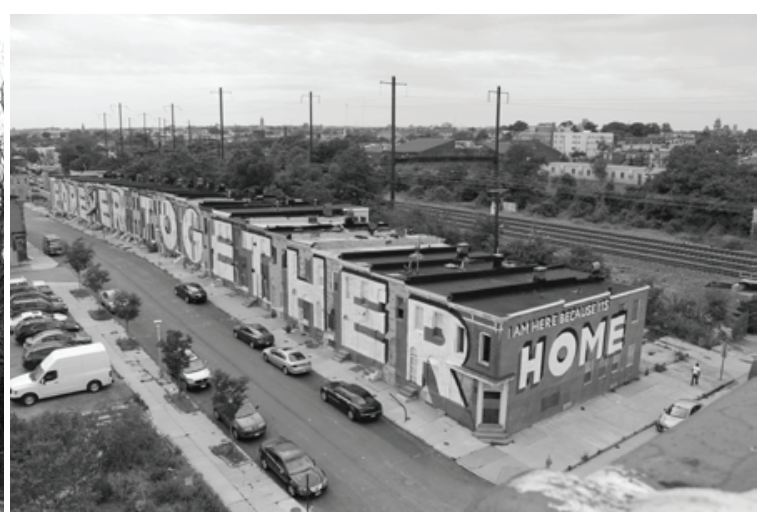

(b)

\section{Illustration 72 A single standing rowhome contrasted against a mural depicting the strong community ties existing in Baltimore.}

The cross section and elevations allows different vantage point, one showing the connection between rowhomes as opposed to the individual lot. An aspect of rowhomes that is not celebrated is the inherent fact that they are a communal typology. Each home shares parti walls with its neighbors, and together they form a contiguous urban face or wall. Rowhomes themselves do not rely entirely on each other, and with additional structural support can stand on their own if needed. The rowhome in this instance is a representation of us as individuals. We can stand on our own if needed, but no one truly desires this permamently. This is the difference between the positioning of the Tiny House in the wilderness and the injection into the city. The wilderness is a temporary escape from others, and the city is the embracing of others.

Welcome your neighbors, support your neighbors, Live Tiny. 


\section{Tiny Community Manifesto}

As we live in the same neighborhood, we are bound together not only by locale, but by the same drive to see that place flourish. Just as a rising tide raises all ships, so shall lifting each other allow for a better community. By living tiny, the city and your community become an extension of your home. The drive to reinvigorate and renovate your community must be present to partake.

It is the intention of these Tiny Interventions to allow the occupants to live together for a better future by providing an example. The main directive is to be inclusive rather than exclusive, the exact opposite of a gated community.

As a start, those that are already looking towards a brighter future, or can most benefit from a stronger sense of community must be grouped together. Included in this, but not limited to, are Entrepeneurs, Urban Farmers, University Students, the Homeless, Doctors, Youth, and the Elderly. Cross referencing this group with neighborhoods close to institutions that can assist in their development (ex. Universities, Entrepeneur Accelerators, existing farms, etc.) allows for a location to be determined (Reference Pages 44-47). Starting with a few homes in neighborhood with many vacants will allow for cheap acquisition as well as the greatest possibility for expansion.

This Thesis acts as a guide, a collection of ideas on how to produce this type of community, who to initially invite into the fold, and inspiration on how to claim a rowhome as a Tiny Home. A startup scenario that places the architect as the promoter, this is the embodiment of the idea that architecture cannot solve the problems of the city, but merely a catalyst of change for the people who will. 


\section{Bibliography}

The Tiny House:

Arendt, Hannah. The Human Condition. Chicago: U of Chicago, 1958. Print.

Cassano, Jay. "The Science Of Why You Should Spend Your Money On Experiences, Not Things.” Co.Exist. N.p., 30 Mar. 2015. Web. 31 Mar. 2016.

Wilson, Lindsay. "How Big Is a House? Average House Size by Country."Shrinkthatfootprintcom. N.p., 30 Apr. 2013. Web. 31 Mar. 2016.

"What Is The Tiny House Movement?" The Tiny Life. N.p., 31 Aug. 2009. Web. 31 Mar. 2016.

"Ecovillage, Intentional Community, Cohousing, Cooperatives, Sustainable Community." PlanetFriendly Guide to Community. N.p., n.d. Web. 31 Mar. 2016. <http://www. planetfriendly.net/community.html\#intros.

Baltimore:

Badger, Emily. "The Long, Painful and Repetitive History of How Baltimore Became Baltimore." Washington Post. The Washington Post, 29 Apr. 2015. Web.

Putting Baltimore's People First: Keys to Responsible Economic Development of Our City. Baltimore, MD: SEIU, 2003. Print.

Philipsen, Klaus. "Anatomy of the (Baltimore) Rowhouse." Community Architect. N.p., 22 Oct. 2012. Web.

Casey, Dana R. "A Child's Memory Of White Flight From Baltimore." The Federalist. N.p., 18 May 2015. Web.

Entrepeneurs:

Florida, Richard. "The Boom Towns and Ghost Towns of the New Economy." The Atlantic. Atlantic Media Company, 18 Sept. 2013. Web.

Wink, Christopher. "How Baltimore Can Become a National Leader in Commercialized Technologies." Technically Media Inc., 7 Oct. 2015. Web. 
Wink, Christopher. "Baltimore Innovation Week 2015: 55+ Events, 120+ Partners, 10K Attendees." Technically Media Inc., 30 Oct. 2015. Web.

University Students:

Brown, Stacey M. "Hundreds Help Clean up after Baltimore Riots." The Baltimore Times. N.p., 4 May 2015. Web.

"The Impact of Johns Hopkins in Baltimore City." The Journal of Blacks in Higher Education No. 25 (1999): 42-43. Web.

Urban Farmers:

"Urban Agriculture - Community Gardening." MRSC. N.p., 26 Feb. 2016. Web.

Wenger, Yvonne. "Baltimore City Council Approves Tax Credits for Urban Farmers." Baltimoresun.com. The Baltimore Sun, 4 May 2015. Web.

Willner, Steven J. "In the Wake of the Freddie Gray Events, Does Senate Bill 541 Provide West Baltimore New Hope?" Ground Rules. MSBA.org, 08 June 2015. Web.

Hayward, Mary Ellen., and Charles Belfoure. The Baltimore Rowhouse. New York: Princeton Architectural, 1999. Print.

Vacant Housing/Homeless:

Barclay, Eliza. "More Cities Are Making It Illegal To Hand Out Food To The Homeless." 22 October 2014. npr.org. News Article. 4 November 2015.

Keyes, Scott. "City Makes It Illegal To Sleep In Publc In Effort To Crack Down On The Homeless." 22 September 2014. ThinkProgress.org. Web Article. 4 November 2015

"Project C.O.R.E." Department of Housing and Community Development. N.p., n.d. Web 


\section{Extended Bibliography}

Broadwater, Luke. “Gov. Hogan Announces \$700M Plan to Target Urban Decay in Baltimore." Baltimoresun.com. N.p., n.d. Web. 5 Jan. 2016.

Kelly, Jacques. "Remembering the Homesteaders of Otterbein." Baltimoresun.com. N.p., 31 Oct. 2014. Web.

McCoy, Terrence. “Baltimore Has More than 16,000 Vacant Houses. Why Can't the Homeless Move In?" Washington Post. The Washington Post, 12 May 2015. Web.

Semuels, Alana. "Could Baltimore's 16,000 Vacant Houses Shelter the City's Homeless?" The Atlantic. Atlantic Media Company, 20 Oct. 2014. Web.

http://www.Baltimore.org

http://www.BaltimoreCollegetown.org

http://www.farmalliancebaltimore.org

http://www.map.baltimoretech.net

http://www.parksandpeople.org/greening/resource-network/

http://www.slumlordwatch.com/ 